\title{
Review of the existing maximum residue levels for mandipropamid according to Article 12 of Regulation (EC) No 396/2005
}

\author{
European Food Safety Authority (EFSA),
}

Alba Brancato, Daniela Brocca, Chloe De Lentdecker, Lucien Ferreira, Luna Greco, Samira Jarrah, Dimitra Kardassi, Renata Leuschner, Christopher Lythgo, Paula Medina, Ileana Miron, Tunde Molnar, Alexandre Nougadere, Ragnor Pedersen, Hermine Reich, Angela Sacchi, Miguel Santos, Alois Stanek, Juergen Sturma, Jose Tarazona, Anne Theobald, Benedicte Vagenende, Alessia Verani and Laura Villamar-Bouza

\begin{abstract}
According to Article 12 of Regulation (EC) No 396/2005, EFSA has reviewed the maximum residue levels (MRLs) currently established at the European level for the pesticide active substance mandipropamid. To assess the occurrence of mandipropamid residues in plants, processed commodities, rotational crops and livestock, EFSA considered the conclusions derived in the framework of Commission Regulation (EU) No 188/2011, the MRLs established by the Codex Alimentarius Commission as well as the European authorisations reported by Member States (including the supporting residues data). Based on the assessment of the available data, MRL proposals were derived and a consumer risk assessment was carried out. Although no apparent risk to consumers was identified, some information required by the regulatory framework was missing. Hence, the consumer risk assessment is considered indicative only and some MRL proposals derived by EFSA still requires further consideration by risk managers.

(c) 2018 European Food Safety Authority. EFSA Journal published by John Wiley and Sons Ltd on behalf of European Food Safety Authority.
\end{abstract}

Keywords: mandipropamid, MRL review, Regulation (EC) No 396/2005, consumer risk assessment, fungicide

Requestor: European Commission

Question number: EFSA-Q-2013-00277

Correspondence: pesticides.mrl@efsa.europa.eu 
Acknowledgement: EFSA wishes to thank the rapporteur Member State Austria for the preparatory work on this scientific output.

Suggested citation: EFSA (European Food Safety Authority), Brancato A, Brocca D, De Lentdecker C, Ferreira L, Greco L, Jarrah S, Kardassi D, Leuschner R, Lythgo C, Medina P, Miron I, Molnar T, Nougadere A, Pedersen R, Reich H, Sacchi A, Santos M, Stanek A, Sturma J, Tarazona J, Theobald A, Vagenende $B$, Verani $A$ and Villamar-Bouza $L$, 2018. Review of the existing maximum residue levels for mandipropamid according to Article 12 of Regulation (EC) No 396/2005. EFSA Journal 2018;16 (5):5284, 46 pp. https://doi.org/10.2903/j.efsa.2018.5284

ISSN: $1831-4732$

(C) 2018 European Food Safety Authority. EFSA Journal published by John Wiley and Sons Ltd on behalf of European Food Safety Authority.

This is an open access article under the terms of the Creative Commons Attribution-NoDerivs License, which permits use and distribution in any medium, provided the original work is properly cited and no modifications or adaptations are made.
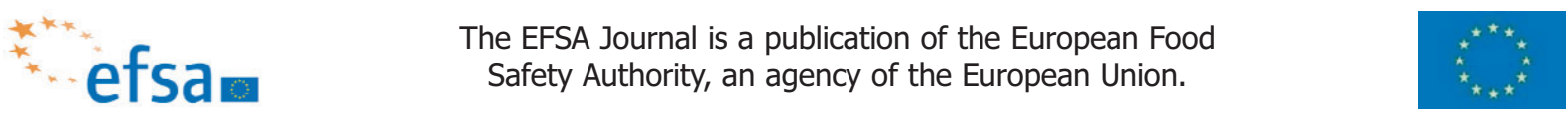


\section{Summary}

Mandipropamid was approved on 1 August 2013 by Commission Implementing Regulation (EU) No 188/2013, in accordance with Regulation (EC) No 1107/2009, as amended by Commission Implementing Regulations (EU) No 540/2011 and 541/2011. As mandipropamid was approved after the entry into force of Regulation (EC) No 396/2005 on 2 September 2008, the European Food Safety Authority (EFSA) is required to provide a reasoned opinion on the review of the existing maximum residue levels (MRLs) for that active substance in compliance with Article 12(1) of the aforementioned regulation. To collect the relevant pesticide residues data, EFSA asked Austria, the designated rapporteur Member State (RMS), to complete the Pesticide Residues Overview File (PROFile) and to prepare a supporting evaluation report. The PROFile and evaluation report provided by the RMS were made available to the Member States (MS). A request for additional information was addressed to the MS in the framework of a completeness check period, which was initiated by EFSA on 10 August 2017 and finalised on 10 October 2017. After having considered all the information provided, EFSA prepared a completeness check report which was made available to MS on 8 November 2017.

Based on the conclusions derived by EFSA in the framework of Commission Regulation (EU) No 188/2011, the MRLs established by the Codex Alimentarius Commission and the additional information provided by the RMS and MS, EFSA prepared in March 2018 a draft reasoned opinion, which was circulated to MS for consultation via a written procedure. Comments received by 30 March 2018 were considered during the finalisation of this reasoned opinion. The following conclusions are derived.

The metabolism of mandipropamid in fruits and leafy vegetables is similar. In roots the metabolism differs from fruits and leafy vegetables, since metabolite SYN 500003 was detected at significant levels. The residue definition for fruits and leafy vegetables is proposed as follows: mandipropamid (any ratio of constituent isomers). For roots the following residue definition for risk assessments is proposed: sum of mandipropamid and SYN 500003. This residue definition is tentative, pending on the submission of toxicological information on SYN 500003. A residue definition for enforcement for all crops under review is proposed as mandipropamid (any ratio of constituent isomers). A validated analytical method for all plant matrices with a limit of quantification (LOQ) of $0.01 \mathrm{mg} / \mathrm{kg}$ is available.

The data on metabolism and distribution of mandipropamid in rotational crops indicated that the metabolism in rotational crops is similar to the pathway observed in primary crops. Significant residues are not expected in rotational crops.

Mandipropamid was stable to hydrolysis under standard conditions of pasteurisation, baking/ brewing/boiling and sterilisation. Studies investigating the magnitude of residues in several processed commodities of tomatoes, grapes, potatoes and hops are available.

The available data are considered sufficient to derive appropriate MRL proposals as well as risk assessment values for all crops under review, apart from root crops since toxicological information on the metabolite SYN 500003 is needed.

Studies investigating the metabolism in livestock were conducted on lactating goats and laying hens. Since the calculated dietary burdens for all groups of livestock were found to be below the trigger value of $0.1 \mathrm{mg} / \mathrm{kg}$ dry matter (DM), further investigation of residues as well as the setting of MRLs in commodities of animal origin is unnecessary.

Chronic consumer exposure resulting from the authorised uses reported in the framework of this review was calculated using revision 2 of the EFSA Pesticides Residues Intake Model (PRIMo). The relevant conversion factor was derived for root crops. The highest chronic exposure was calculated for FR toddler representing $2.8 \%$ of the acceptable daily intake (ADI). Apart from the MRLs evaluated in the framework of this review, internationally recommended CXLS (codex maximum residue limits) have also been established for mandipropamid. Additional calculations of the consumer exposure, considering these CXLs, were therefore carried out. The highest chronic exposure was calculated for $\mathrm{NL}$ children representing $5.0 \%$ of the ADI. 


\section{Table of contents}

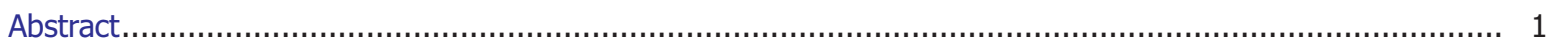

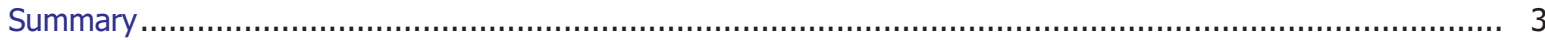

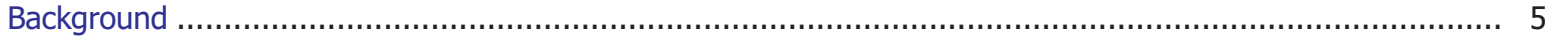

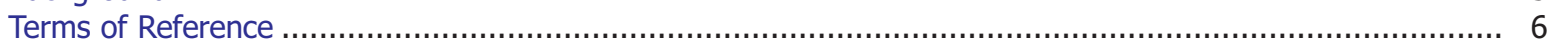

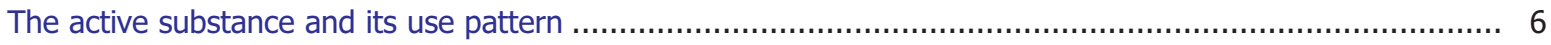

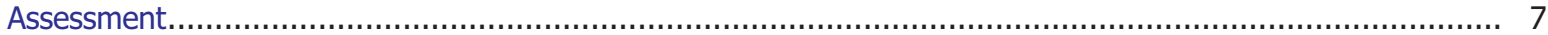

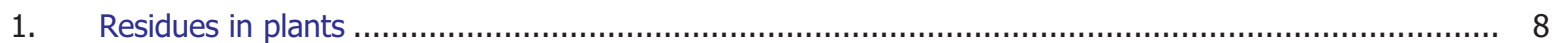

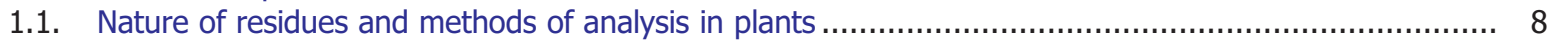

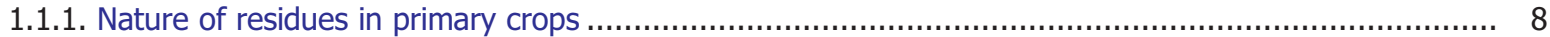

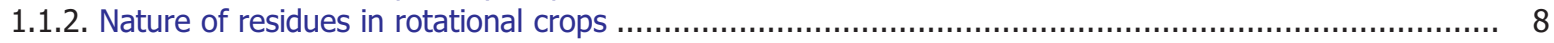

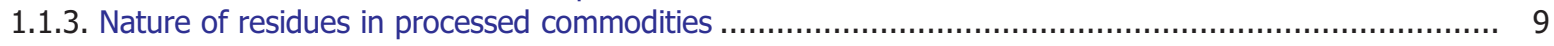

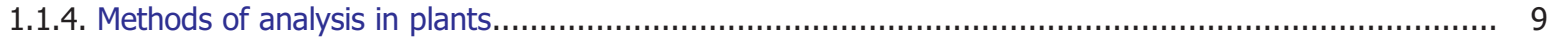

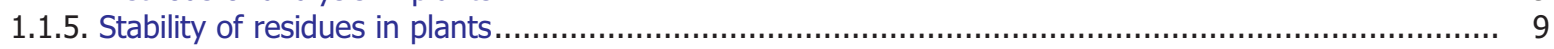

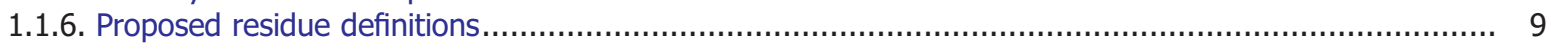

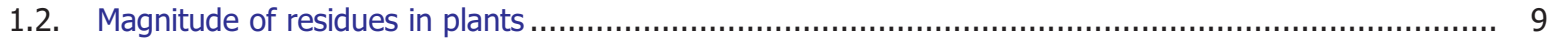

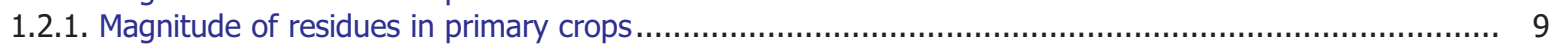

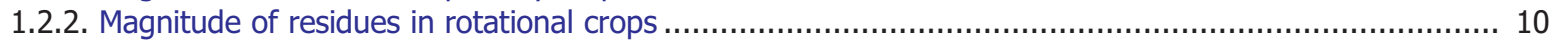

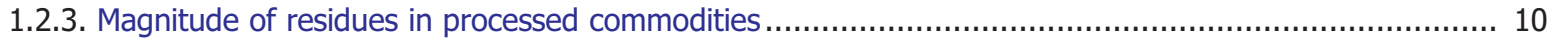

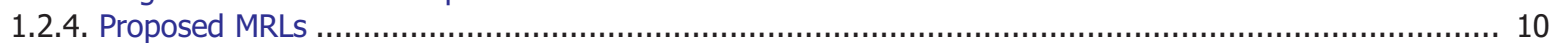

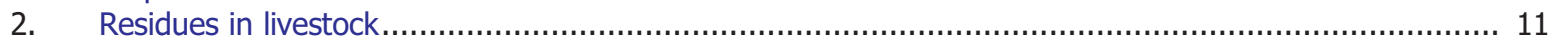

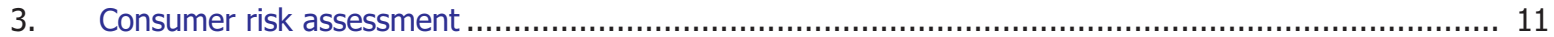

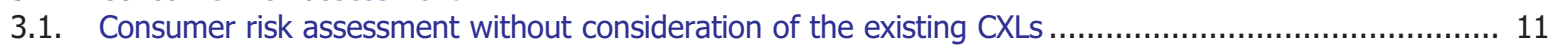

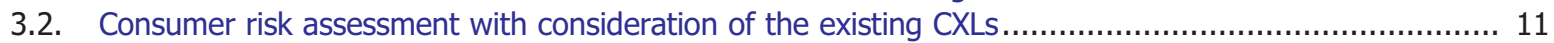

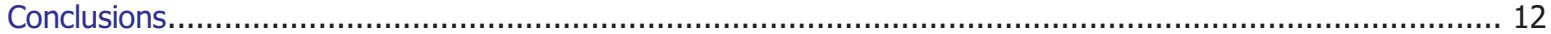

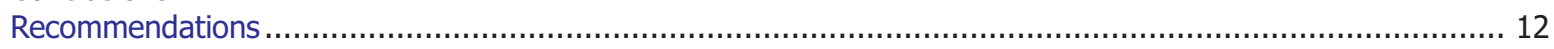

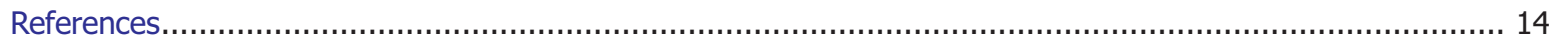

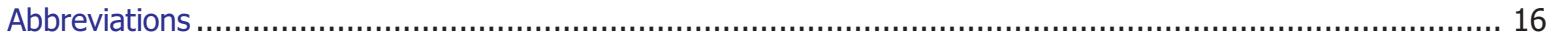

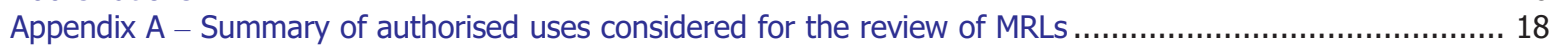

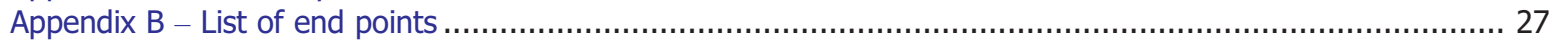

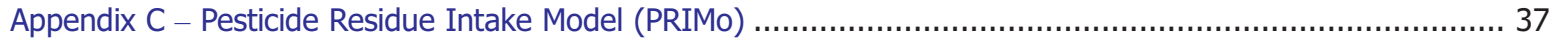

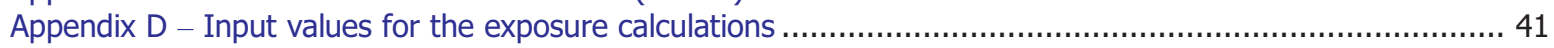

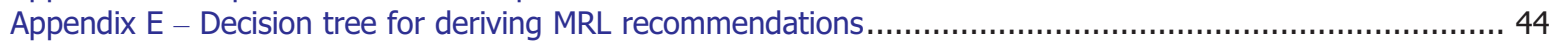

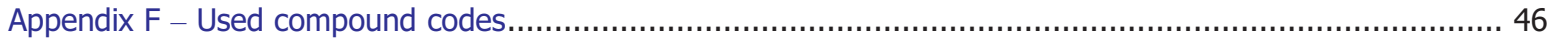




\section{Background}

Regulation (EC) No $396 / 2005^{1}$ (hereinafter referred to as 'the Regulation') establishes the rules governing the setting and the review of pesticide maximum residue levels (MRLs) at the European level. Article 12(1) of that Regulation stipulates that the European Food Safety Authority (EFSA) shall provide within 12 months from the date of the inclusion or non-inclusion of an active substance in Annex I to Directive $91 / 414 /$ EEC $^{2}$ a reasoned opinion on the review of the existing MRLs for that active substance. As mandipropamid was approved on 1 August 2013 by means of Commission Implementing Regulation (EU) No $188 / 2013^{3}$, in accordance with Regulation (EC) No $1107 / 2009^{4}$, as amended by Commission Implementing Regulations (EU) No $540 / 2011^{5}$ and $541 / 2011^{6}$, EFSA initiated the review of all existing MRLs for that active substance.

According to the legal provisions, EFSA shall base its reasoned opinion in particular on the relevant assessment report prepared under Directive 91/414/EEC. It should be noted, however, that, in the framework of Directive 91/414/EEC, only a few representative uses are evaluated, whereas MRLs set out in Regulation (EC) No 396/2005 should accommodate all uses authorised within the European Union (EU), and uses authorised in third countries that have a significant impact on international trade. The information included in the assessment report prepared under Directive 91/414/EEC is therefore insufficient for the assessment of all existing MRLs for a given active substance.

To gain an overview of the pesticide residues data that have been considered for the setting of the existing MRLs, EFSA developed the Pesticide Residues Overview File (PROFile). The PROFile is an inventory of all pesticide residues data relevant to the risk assessment and MRL setting for a given active substance. This includes data on:

- the nature and magnitude of residues in primary crops;

- the nature and magnitude of residues in processed commodities;

- the nature and magnitude of residues in rotational crops;

- the nature and magnitude of residues in livestock commodities;

- the analytical methods for enforcement of the proposed MRLs.

Austria, the designated rapporteur Member State (RMS) in the framework of Commission Regulation (EU) No $188 / 2011^{7}$, was asked to complete the PROFile for mandipropamid and to prepare a supporting evaluation report (Austria, 2013). The PROFile and the supporting evaluation report were submitted to EFSA on 28 May 2013 and made available to the MS. A request for additional information was addressed to the MS in the framework of a completeness check period which was initiated by EFSA on 10 August 2017 and finalised on 10 October 2017. Additional evaluation reports were submitted by Austria, Belgium, Portugal, Germany, the United Kingdom, Spain, France, Italy, the Netherlands, Greece and the European Union Reference Laboratories for Pesticide Residues (Austria, 2017; Belgium, 2017; EURL, 2017; France, 2017; Germany, 2017; Greece 2017; Italy, 2017; Netherlands, 2017; Portugal, 2017; Spain, 2017; United Kingdom, 2017) and, after having considered all the information provided by the RMS and MS, EFSA prepared a completeness check report which was made available to all MS on 8 November 2017. Further clarifications were sought from MS via a written procedure in November 2017.

\footnotetext{
${ }^{1}$ Regulation (EC) No 396/2005 of the European Parliament and of the Council of 23 February 2005 on maximum residue levels of pesticides in or on food and feed of plant and animal origin and amending Council Directive 91/414/EEC. OJ L 70, 16.3.2005, p. $1-16$.

${ }^{2}$ Council Directive $91 / 414 /$ EEC of 15 July 1991 concerning the placing of plant protection products on the market. OJ L 230, 19.8.1991, p. 1-32. Repealed by Regulation (EC) No 1107/2009.

${ }^{3}$ Commission Implementing Regulation (EU) No 188/2013 of 5 March 2013 approving the active substance mandipropamid, in accordance with Regulation (EC) No 1107/2009 of the European Parliament and of the Council concerning the placing of plant protection products on the market, and amending the Annex to Commission Implementing Regulation (EU) No 540/2011. OJ L $62,6.3 .2013$, p. $13-16$.

${ }^{4}$ Regulation (EC) No 1107/2009 of the European Parliament and of the Council of 21 October 2009 concerning the placing of plant protection products on the market and repealing Council Directives 79/117/EEC and 91/414/EEC. OJ L 309, 24.11.2009, p. $1-50$.

5 Commission Implementing Regulation (EU) No 540/2011 of 25 May 2011 implementing Regulation (EC) No 1107/2009 of the European Parliament and of the Council as regards the list of approved active substances. OJ L 153, 11.6.2011, p. 1-186.

${ }^{6}$ Commission Implementing Regulation (EU) No 541/2011 of 1 June 2011 amending Implementing Regulation (EU) No 540/2011 implementing Regulation (EC) No 1107/2009 of the European Parliament and of the Council as regards the list of approved active substances. OJ L 153, 11.6.2011, p. 187-188.

7 Commission Regulation (EU) No 188/2011 of 25 February 2011 laying down detailed rules for the implementation of Council Directive 91/414/EEC as regards the procedure for the assessment of active substances which were not on the market 2 years
} after the date of notification of that Directive. OJ No L 53, 26.2.2011, p. 51-55. 
Based on the conclusions derived by EFSA in the framework of Commission Regulation (EU) No 188/2011, the MRLs established by the Codex Alimentarius Commission (codex maximum residue limit; CXLs) and the additional information provided by the MS, EFSA prepared in March 2018 a draft reasoned opinion, which was submitted to MS for commenting via a written procedure. All comments received by 30 March 2018 were considered by EFSA during the finalisation of the reasoned opinion.

The evaluation report submitted by the RMS (Austria, 2013) and the evaluation reports submitted by MS Austria, Belgium, Portugal, Germany, the United Kingdom, Spain, France, Italy, the Netherlands, Greece, Sweden and the EURL (Austria, 2017; Belgium, 2017; EURL, 2017; France, 2017; Germany, 2017; Greece 2017; Italy, 2017; Netherlands, 2017; Portugal, 2017; Spain, 2017; Sweden, 2017; United Kingdom, 2017) are considered as supporting documents to this reasoned opinion and, thus, are made publicly available.

In addition, key supporting documents to this reasoned opinion are the completeness check report (EFSA, 2018a) and the MS consultation report (EFSA, 2018b). These reports are developed to address all issues raised in the course of the review, from the initial completeness check to the reasoned opinion. Also, the chronic exposure calculations for all crops reported in the framework of this review performed using the EFSA Pesticide Residues Intake Model (PRIMo) (Excel file) and the PROFile are key supporting documents and made publicly available as background documents to this reasoned opinion. Furthermore, a screenshot of the Report sheet of the PRIMo is presented in Appendix C.

\section{Terms of Reference}

According to Article 12 of Regulation (EC) No 396/2005, EFSA shall provide a reasoned opinion on:

- the inclusion of the active substance in Annex IV to the Regulation, when appropriate;

- the necessity of setting new MRLs for the active substance or deleting/modifying existing MRLs set out in Annex II or III of the Regulation;

- the inclusion of the recommended MRLs in Annex II or III to the Regulation;

- the setting of specific processing factors as referred to in Article 20(2) of the Regulation.

\section{The active substance and its use pattern}

Mandipropamid is the ISO common name for (RS)-2-(4-chlorophenyl)- $N$-[3-methoxy-4-(prop-2ynyloxy)phenethyl]-2-(prop-2-ynyloxy)acetamide (IUPAC). It is a fungicide and is effective against oomycete plant pathogens in a range of crops, i.e. against downy mildews, such as Plasmopara viticola on grapes and potato late blight caused by Phytophthora infestans. The proposed fungicidal mode of action is by inhibition of phospholipid biosynthesis and uptake studies with $\mathrm{C}^{14}$-labelled mandipropamid showed that it acts on the cell wall and does not enter the cell. Furthermore, $\mathrm{C}^{14}$ glucose incorporation into cellulose was perturbed in the presence of mandipropamid which, taken together, suggests that the inhibition of cellulose synthesis is the primary effect of mandipropamid (Austria, 2013).

The chemical structure of the active substance and its main metabolites is reported in Appendix $F$.

Mandipropamid was evaluated in the framework of Commission Regulation (EU) No 188/2011 with Austria designated as RMS. The representative uses evaluated in the peer review process comprised of foliar spraying against fungi on greenhouse crops of melon, tomato, lettuce and cucumber and field crops of potato, tomato, melon, cucumber, lettuce and grapes. Following the peer review, which was carried out by EFSA, a decision on approval of the active substance was published by means of Commission Implementing Regulation (EU) No 188/2013 in accordance with Regulation (EC) No 1107/2009, and entered into force on 1 August 2013.

The EU MRLs for mandipropamid are established in Annex IIIA of Regulation (EC) No 396/2005 and codex maximum residue limits (CXLS) for mandipropamid were also established by the Codex Alimentarius Commission (CAC). An overview of the MRL changes that occurred since the entry into force of the Regulation mentioned above is provided below (Table 1). 
Table 1: $\quad$ Overview of the MRL changes since the entry into force of Regulation (EC) No 396/2005

\begin{tabular}{l|l|l}
\hline Procedure & Legal implementation & Remarks \\
\hline $\begin{array}{l}\text { MRL application } \\
\text { (EFSA, 2013) }\end{array}$ & $\begin{array}{l}\text { Commission Regulation (EC) } \\
\text { No } 737 / 2014^{(a)}\end{array}$ & $\begin{array}{l}\text { Reasoned opinion on the modification of the existing MRL for } \\
\text { mandipropamid in tomato. }\end{array}$ \\
\hline $\begin{array}{l}\text { MRL application } \\
\text { (EFSA, 2011) }\end{array}$ & $\begin{array}{l}\text { Commission Regulation (EC) } \\
\text { No } 812 / 2011^{(b)}\end{array}$ & $\begin{array}{l}\text { Reasoned opinion on the modification of the existing MRL for } \\
\text { mandipropamid in hops. }\end{array}$ \\
\hline $\begin{array}{l}\text { MRL application } \\
\text { (EFSA, 2009a) }\end{array}$ & $\begin{array}{l}\text { Commission Regulation (EC) } 822 / 2009^{(c)} \\
\text { Neasoned opinion on the modification of the existing MRLs for } \\
\text { mandipropamid in several leafy vegetables (red mustard, leaves } \\
\text { and sprouts of brassica, spinach, purslane and beet leaves). }\end{array}$ \\
\hline $\begin{array}{l}\text { Implementation } \\
\text { of CAC 2009 }\end{array}$ & $\begin{array}{l}\text { Commission Regulation (EU) } \\
\text { No } 45 / 2010^{(d)}\end{array}$ & \\
\hline $\begin{array}{l}\text { Implementation } \\
\text { of CAC 2014 }\end{array}$ & \begin{tabular}{l} 
Commission Regulation (EU) $2015 / 845^{(\mathrm{e})}$ \\
\hline
\end{tabular}
\end{tabular}

(a): Commission Regulation (EU) No 737/2014 of 24 June 2014 amending Annexes II and III to Regulation (EC) No 396/2005 of the European Parliament and of the Council as regards maximum residue levels for 2-phenylphenol, chlormequat, cyflufenamid, cyfluthrin, dicamba, fluopicolide, flutriafol, fosetyl, indoxacarb, isoprothiolane, mandipropamid, metaldehyde, metconazole, phosmet, picloram, propyzamide, pyriproxyfen, saflufenacil, spinosad and trifloxystrobin in or on certain products. OJ L 202, 10.7.2014, p. 1-63.

(b): Commission Regulation (EU) No 812/2011 of 10 August 2011 amending Annex III to Regulation (EC) No 396/2005 of the European Parliament and of the Council as regards maximum residue levels for dimethomorph, fluopicolide, mandipropamid, metrafenone, nicotine and spirotetramat in or on certain products. OJ L 208, 13.8.2011, p. 1-22.

(c): Regulation (EC) No 396/2005 of the European Parliament and of the Council as regards maximum residue levels for azoxystrobin, atrazine, chlormequat, cyprodinil, dithiocarbamates, fludioxonil, fluroxypyr, indoxacarb, mandipropamid, potassium tri-iodide, spirotetramat, tetraconazole, and thiram in or on certain products. OJ L 239, 10.9.2009, p. 5-45.

(d): Commission Regulation (EU) No 459/2010 of 27 May 2010 amending Annexes II, III and IV to Regulation (EC) No 396/2005 of the European Parliament and of the Council as regards maximum residue levels for certain pesticides in or on certain products. OJ L 129, 28.5.2010, p. 3-49.

(e): Commission Regulation (EU) 2015/845 of 27 May 2015 amending Annexes II and III to Regulation (EC) No 396/2005 of the European Parliament and of the Council as regards maximum residue levels for azoxystrobin, chlorantraniliprole, cyantraniliprole, dicamba, difenoconazole, fenpyroximate, fludioxonil, glufosinate-ammonium, imazapic, imazapyr, indoxacarb, isoxaflutole, mandipropamid, penthiopyrad, propiconazole, pyrimethanil, spirotetramat and trinexapac in or on certain products. OJ L 138, 4.6.2015, p. 1-69.

For the purpose of this MRL review, the critical uses of mandipropamid currently authorised within the EU have been collected by the RMS and reported in the PROFile. The additional good agricultural practices (GAPs) reported by MS during the completeness check were also considered. The details of the authorised GAP(s) for mandipropamid are given in Appendix A. The RMS did not report any use authorised in third countries that might have a significant impact on international trade.

\section{Assessment}

EFSA has based its assessment on the PROFile submitted by the RMS, the evaluation report accompanying the PROFile (Austria, 2013), the draft assessment report (DAR) and its addenda prepared under Council Directive 91/414/EEC and in the framework of Commission Regulation (EU) No 188/2011 (Austria, 2006, 2012), the conclusion on the peer review of the pesticide risk assessment of the active substance mandipropamid (EFSA, 2012), the Joint Meeting on Pesticide residues (JMPR) Evaluation report (FAO, 2008, 2013), the previous reasoned opinions on mandipropamid (EFSA, 2009a,b, 2011, 2013) as well as the evaluation reports submitted during the completeness check (Austria, 2017; Belgium, 2017; EURL, 2017; France, 2017; Germany, 2017; Greece 2017; Italy, 2017; Netherlands, 2017; Portugal, 2017; Spain, 2017; Sweden, 2017; United Kingdom, 2017). The assessment is performed in accordance with the legal provisions of the uniform principles for evaluation and authorisation of plant protection products as set out in Commission Regulation (EU) No 546/2011 and the currently applicable guidance documents relevant for the consumer risk assessment of pesticide residues (European Commission, 1997a-g, 2000, 2010a,b, 2017; OECD, 2011, 2013).

More detailed information on the available data and on the conclusions derived by EFSA can be retrieved from the list of end points reported in Appendix B.

\footnotetext{
${ }^{8}$ Commission Regulation (EU) No 546/2011 of 10 June 2011 implementing Regulation (EC) No 1107/2009 of the European Parliament and of the Council as regards uniform principles for evaluation and authorisation of plant protection products. OJ $\mathrm{L}$ $155,11.06 .2011$, p. 127-175.
} 


\section{Residues in plants}

\subsection{Nature of residues and methods of analysis in plants}

\subsubsection{Nature of residues in primary crops}

The metabolism of mandipropamid was investigated in fruits (grapes, tomatoes), leafy vegetables and root crops in the framework of the peer review (EFSA, 2012). Studies on grapes, lettuce and potatoes were conducted with ${ }^{14} \mathrm{C}$-mandipropamid labelled either on the methoxyphenyl or the chlorophenyl ring. The metabolism study on tomato was conducted with $\left[1-\mathrm{C}^{14}\right]$ labelled mandipropamid.

After six foliar applications of ca $150 \mathrm{~g}$ active substance (a.s.)/ha or six foliar applications of $411-464 \mathrm{~g}$ a.s./ha on grapes, mandipropamid was the major component of the residues representing most of the fruit radioactivity $79-89 \%$ TRR. All other metabolite fractions in grape fruits were lower than $3.5-3.8 \%$ TRR. After two foliar applications of $250 \mathrm{~g}$ a.s./ha and two foliar applications of $150 \mathrm{~g}$ a.s./ha on tomatoes, mandipropamid was the major component of the residues representing 75\% TRR. Mandipropamid showed a slow penetration/translocation of radioactivity into tomato plants. It is slowly metabolised to many metabolites, which occurred only at very small amount.

After two foliar applications of ca $150 \mathrm{~g}$ a.s./ha on lettuce, mandipropamid was the major component of the residues representing $94-95 \%$ of the TRR. None of the identified metabolites were greater than $0.4 \%$ TRR $(0.005 \mathrm{mg} \mathrm{eq} / \mathrm{kg})$.

Potatoes were treated with six foliar applications of $150 \mathrm{~g}$ a.s./ha (1N rate) or with six foliar applications of approximately $418-458 \mathrm{~g}$ a.s./ha (3N rate). In the $1 \mathrm{~N}$ rate trials, mandipropamid was detected at amounts lower than $0.01 \mathrm{mg} \mathrm{eq} / \mathrm{kg}$ in the peel, flesh and whole potato in both labels at pre-harvest interval (PHI) 7 and 21 days. The metabolite SYN 500003 was the only metabolite observed in potato peel $(0.002-0.003 \mathrm{mg} \mathrm{eq} / \mathrm{kg})$, potato flesh $(0.006-0.009 \mathrm{mg}$ eq/ $/ \mathrm{kg})$ and in the whole potato $(0.008-0.0115 \mathrm{mg} \mathrm{eq} / \mathrm{kg})$. In the $3 \mathrm{~N}$ rate trials, mandipropamid was observed at $12 \%$ TRR in potato peel $(0.020 \mathrm{mg} \mathrm{eq} / \mathrm{kg})$ and $3 \%$ TRR in the whole potato $(0.029 \mathrm{mg} \mathrm{eq} / \mathrm{kg})$, while SYN 500003 was observed at $11-13 \%$ TRR with levels of 0.02 and $0.08 \mathrm{mg} \mathrm{eq} / \mathrm{kg}$ in potato peel and flesh, and $0.10 \mathrm{mg} \mathrm{eq} / \mathrm{kg}$ in the whole potato. In conclusion, at the $1 \mathrm{~N}$ rate the only residues present at significant amounts are of metabolite SYN 500003.

In addition, EFSA emphasises that the above studies do not investigate the possible impact of plant metabolism on the isomer ratio of mandipropamid and further investigation on this matter would in principle be required. Since guidance on the consideration of isomer ratios in the consumer risk assessment is not yet available, EFSA recommends that this issue is reconsidered when such guidance is available.

\subsubsection{Nature of residues in rotational crops}

Mandipropamid is authorised on crops that may be grown in rotation. The field DT90 reported in the field soil dissipation studies evaluated in the framework of the peer review was 42.1-240 days (EFSA, 2012).

Two confined rotational crop studies were assessed in the framework of the peer review (EFSA, 2012). Mandipropamid labelled either on the chlorophenyl or on the methoxyphenyl ring was applied to bare soil at a rate of ca $900 \mathrm{~g}$ a.s./ha. Lettuce, radish and wheat were planted at plant back intervals (PBI) of 29, 58, 120 and 365 days after treatment (DAT). In the methoxyphenyl label study only lettuce and wheat were planted 365 DAT.

In the study with mandipropamid labelled on the chlorophenyl ring, the TRR was lower than $0.01 \mathrm{mg} \mathrm{eq} / \mathrm{kg}$ for mandipropamid and metabolites CGA 380778 and NOA 458422 in all plant commodities with the exception of the wheat straw where residues of mandipropamid were 0.02 and $0.015 \mathrm{mg} \mathrm{eq} / \mathrm{kg}$ at 29 and 58 DAT, respectively, while metabolite NOA 458422 was detected at $0.016 \mathrm{mg} \mathrm{eq} / \mathrm{kg}$ at 29 DAT.

In the study with mandipropamid labelled on the methoxyphenyl ring the same pattern was observed. The TRR was lower than $0.01 \mathrm{mg}$ eq/ $\mathrm{kg}$ for mandipropamid and metabolites CGA 380778 and NOA 458422 in all plant commodities with the exception of wheat straw where residues of mandipropamid were 0.021 and $0.023 \mathrm{mg} \mathrm{eq} / \mathrm{kg}$ at 29 and 58 DAT, respectively, while metabolite NOA 458422 was detected at $0.016 \mathrm{mg} \mathrm{eq} / \mathrm{kg}$ at 29 and 58 DAT. After 210 DAT, residue levels of mandipropamid and metabolites were below $0.01 \mathrm{mg} / \mathrm{kg}$ in all crops.

The metabolites formed (CGA 380778 and NOA 458422) were also identified in primary plant metabolism studies as well as in soil metabolism studies (Austria, 2013). The data on metabolism and 
distribution of mandipropamid in rotational crops indicated that the metabolism of mandipropamid in rotational crops is similar to the pathway observed in primary crops.

\subsubsection{Nature of residues in processed commodities}

Studies investigating the nature of residues in processed commodities were assessed in the framework of the peer review (EFSA, 2012). Studies were conducted with radiolabelled mandipropamid simulating representative hydrolytic conditions for pasteurisation $\left(20 \mathrm{~min}\right.$ at $\left.90^{\circ} \mathrm{C}, \mathrm{pH} 4\right)$, boiling/brewing/baking $\left(60 \mathrm{~min}\right.$ at $\left.100^{\circ} \mathrm{C}, \mathrm{pH} 5\right)$ and sterilisation $\left(20 \mathrm{~min}\right.$ at $\left.120^{\circ} \mathrm{C}, \mathrm{pH} 6\right)$. Mandipropamid was stable to hydrolysis under standard conditions of pasteurisation, baking/brewing/boiling and sterilisation.

\subsubsection{Methods of analysis in plants}

During the peer review, a multi-residue analytical method using liquid chromatography with tandem mass spectrometry (LC-MS/MS) was validated for the determination of mandipropamid in high water, high acid, high oil and dry content commodities with a LOQ of $0.01 \mathrm{mg} / \mathrm{kg}$ (EFSA, 2012). Furthermore, the EURL reported a multi-residue analytical method using LC-MS/MS for the four main plant matrices with a LOQ of $0.01 \mathrm{mg} / \mathrm{kg}$ (EURL, 2017). A multi-residue analytical method using LC-MS/MS for the four main plant matrices with a LOQ of $0.01 \mathrm{mg} / \mathrm{kg}$ was also reported by Greece (2017). Hence, it is concluded that mandipropamid can be enforced with a LOQ of $0.01 \mathrm{mg} / \mathrm{kg}$ in high water content, high acid content, high oil content and dry commodities.

\subsubsection{Stability of residues in plants}

In the framework of the peer review, storage stability of mandipropamid was demonstrated for a period of 12 months at $-20^{\circ} \mathrm{C}$ in high water, high acid, high oil and dry matrices (EFSA, 2012). Furthermore, the storage stability of mandipropamid was demonstrated for a period of 24 months at $-20^{\circ} \mathrm{C}$ in high water content, high acid, high oil content matrices and dry commodities (Austria, 2013). Metabolite SYN 500003 was stable at $-20^{\circ} \mathrm{C}$ for up to 32 months in potato tubers, granules/flakes, chips and wet peel (Austria, 2013).

\subsubsection{Proposed residue definitions}

The metabolism of mandipropamid is similar in fruits and leafy vegetables. However, the metabolism observed in roots was different since significant amounts of the metabolite SYN 500003 were observed.

For this MRL review, the residue definition for risk assessment for fruits and leafy vegetables is proposed as follows: mandipropamid (any ratio of constituent isomers). For roots, the residue definition for risk assessment is proposed as follows: sum of mandipropamid and SYN 500003. The residue definition for roots is tentative pending on the submission of toxicological information on the metabolite SYN 500003.

It should be noted that the RMS proposed the use of the threshold of toxicological concern (TTC) approach to address the toxicity of the metabolite SYN 500003 (Austria, 2017). However, EFSA considers that a complete genotoxicity data package to address the genotoxic potential of the metabolite and repeated dose toxicity study to check whether the metabolite SYN 500003 is of lower, similar or higher toxicity in comparison with the parent mandipropamid are required. Therefore, EFSA considered that the TTC approach is not applicable as explained above.

For enforcement, the residue definition for all crops under review is proposed as follows: mandipropamid (any ratio of constituent isomers). An analytical method for the enforcement of the proposed residue definition at the LOQ of $0.01 \mathrm{mg} / \mathrm{kg}$ in all matrices is available.

\subsection{Magnitude of residues in plants}

\subsubsection{Magnitude of residues in primary crops}

To assess the magnitude of mandipropamid residues resulting from the reported GAPs, EFSA considered all residue trials reported by the RMS in its evaluation report (Austria, 2017), including residue trials evaluated in the framework of the peer review (EFSA, 2012) or in the framework of a previous MRL application (EFSA, 2009a,b, 2011, 2013) and additional data submitted during the 
completeness check (Greece, 2017). All residue trial samples considered in this framework were stored in compliance with the demonstrated storage conditions.

The number of residue trials and extrapolations were evaluated in accordance with the European guidelines on comparability, extrapolation, group tolerances and data requirements for setting MRLS (European Commission, 2017).

For all the crops, the available residue trials are sufficient to derive MRL and risk assessment values, taking note of the following considerations:

- Tomatoes: Although appropriate MRL and risk assessment values can be derived from the indoor data, five trials compliant with the northern GAP are still required.

- Courgettes: Although appropriate MRL and risk assessment values can be derived from the indoor data, four trials compliant with the northern GAP are still required. It is also noted that one additional trial compliant with the southern GAP is still desirable to complete the data set (minor deficiency).

A conversion factor of 2 was applied to root crops, based on the levels of mandipropamid and metabolite SYN 500003 detected in the residue trials performed with potatoes.

\subsubsection{Magnitude of residues in rotational crops}

There were no studies investigating the magnitude of residues in rotational crops available for this review. Greece in its evaluation report mentioned a field rotational crop study; however, no study could be found in the document (Greece, 2017).

The maximum application rate proposed for crops that can be grown in rotation is $900 \mathrm{~g}$ a.s./ha. It is noted that the application in the confined rotational crop studies was done onto bare soil and thus represents a worst-case scenario of exposure (no foliar interception). A part of mandipropamid is expected to be intercepted by the treated crops since the applications are done until a late growth stage (PHI 3-7 days). Therefore, it can be concluded that significant residue levels are not expected in succeeding crops provided that mandipropamid is applied according to the current authorisations reported in Appendix A.

\subsubsection{Magnitude of residues in processed commodities}

The effect of industrial processing and/or household preparation was assessed on studies conducted on apples, citrus, grapes, tomato and rice (EFSA, 2012; Austria, 2013). An overview of the processing studies is available in Appendix B.1.2.3. Robust processing factors could be derived for grapes (pomace (wet and dry), red wine, juice, and raisins), tomato (washed, juice, pomace (wet), canned, puree) and hops (beer) and limited processing factors (not sufficiently supported by data) for potatoes (fried, crisps, granules (flakes) and process waste (wet peel)) and grapes (red wine must heated).

Further processing studies are not required as they are not expected to affect the outcome of the risk assessment. However, if more robust processing factors were to be required by risk managers, in particular for enforcement purposes, additional processing studies would be needed.

\subsubsection{Proposed MRLs}

The available data are considered sufficient to derive MRL proposals as well as risk assessment values for all commodities under evaluation, except for potatoes, since toxicological information on the metabolite SYN 500003 is not available.

\section{Residues in livestock}

Mandipropamid is authorised for use on potatoes that might be fed to livestock. Livestock dietary burden calculations were therefore performed for different groups of livestock according to OECD guidance (OECD, 2013), which has now also been agreed upon at the European level. The input values for all relevant commodities are summarised in Appendix D. Since the calculated dietary burdens for all groups of livestock were found to be below the trigger value of $0.1 \mathrm{mg} / \mathrm{kg}$ dry matter (DM), further investigation of residues as well as the setting of MRLs in commodities of animal origin is unnecessary.

Although not required, studies to investigate metabolism in livestock were conducted on lactating goats (EFSA, 2012) and laying hens (Greece, 2017). Lactating goats were dosed with mandipropamid 
labelled in the chlorophenyl and methoxyphenyl rings over 7 days with 31-54 mg/kg DM. Most of the radioactivity was excreted via urine and faeces and less than $0.23 \%$ of the administered radioactivity was recovered in milk and tissues with the highest levels in liver $(0.48 \mathrm{mg} \mathrm{eq} / \mathrm{kg})$ and kidney $(0.14 \mathrm{mg}$ $\mathrm{eq} / \mathrm{kg}$ ). Laying hens were dosed with mandipropamid labelled in the chlorophenyl and methoxyphenyl rings over 14 days with $22-24 \mathrm{mg} / \mathrm{kg}$ DM. The majority TRR was detected in excreta (83-85\%). The only relevant residues were detected in egg whites, where mandipropamid was observed at $34-37 \%$ TRR $(0.016-0.018 \mathrm{mg} \mathrm{eq} / \mathrm{kg})$. In all other tissues, mandipropamid and metabolites were below $0.01 \mathrm{mg} / \mathrm{kg}$.

In the framework of the peer review, the residue definition for enforcement was proposed as mandipropamid (sum of isomers) and the residue definition for risk assessment as mandipropamid only (EFSA, 2012). It is noted however that for this MRL review residue, definitions for livestock are not needed.

If future uses would lead to the need to derive a residue definition for livestock and based on the metabolism studies assessed above, the residue definition for enforcement and risk assessment could be proposed as follows: mandipropamid (any ratio of constituent isomers).

No feeding studies were available or required for this MRL review. Two validated analytical methods for animal matrices each with a LOQ of $0.01 \mathrm{mg} / \mathrm{kg}$ were reported by the RMS (Austria, 2013) and Greece (2017).

\section{Consumer risk assessment}

In the framework of this review, only the uses of mandipropamid reported by the RMS in Appendix A were considered; however, the use of mandipropamid was previously also assessed by the JMPR (FAO, 2008, 2013). The CXLs, resulting from these assessments by JMPR and adopted by the $\mathrm{CAC}$, are now international recommendations that need to be considered by European risk managers when establishing MRLs. To facilitate consideration of these CXLs by risk managers, the consumer exposure was calculated both with and without consideration of the existing CXLs.

\subsection{Consumer risk assessment without consideration of the existing CXLS}

Chronic exposure calculations for all crops reported in the framework of this review were performed using revision 2 of the EFSA PRIMo (EFSA, 2007). Input values for the exposure calculations were derived in compliance with the decision tree reported in Appendix E. For all commodities STMR were derived by EFSA in the framework of this review and used to perform the risk assessment according to the internationally agreed methodologies (FAO, 2009). All input values included in the exposure calculations are summarised in Appendix D. Acute exposure calculations were not carried out because an acute reference dose (ARfD) was not deemed necessary for mandipropamid. The relevant conversion factor was applied to roots.

The exposure values calculated were compared with the toxicological reference value for mandipropamid, derived by EFSA (2012) under Commission Regulation (EU) No 188/2011. The highest chronic exposure was calculated for French toddler, representing $2.8 \%$ of the acceptable daily intake (ADI). It should be noted that the consumer risk assessment was performed without information about the toxicity of metabolite SYN 500003 (relevant for the assessment of potatoes). Although some uncertainties remain due to the data gaps identified in the previous sections, this indicative exposure calculation did not indicate a risk to consumers.

It must be noted that mandipropamid is a racemic mixture of a pair of enantiomers, but the possible preferential metabolism/degradation of each enantiomer in animals and plants and the enantiomeric forms of the resulting metabolites that retain the chiral centre in animals and plants was not investigated in the studies assessed in this MLR review. However, the possible impact of each individual mandipropamid enantiomer was considered acceptable due to the high margin of safety observed in the consumer risk assessment.

\subsection{Consumer risk assessment with consideration of the existing CXLs}

To include the CXLs in the calculations of the consumer exposure, CXLs were compared with the EU MRL proposals in compliance with Appendix $\mathrm{E}$ and all data relevant to the consumer exposure assessment have been collected from JMPR evaluations. An overview of the input values used for this 
exposure calculation is also provided in Appendix D. For root crops, the relevant conversion factor was applied.

Chronic exposure calculations were also performed using revision 2 of the EFSA PRIMo and the exposure values calculated were compared with the toxicological reference value derived for mandipropamid. The highest chronic exposure was calculated for the Dutch children representing $5.0 \%$ of the ADI. It should be noted that the consumer risk assessment was performed without information about the toxicity of metabolite SYN 500003 (relevant for the assessment of potatoes, onions and spring onions). Although uncertainties remain due to the data gaps identified for a certain number of these CXLS, this indicative exposure calculation did not indicate a risk to consumers.

It must be noted that mandipropamid is a racemic mixture of a pair of enantiomers, but the possible preferential metabolism/degradation of each enantiomer in animals and plants and the enantiomeric forms of the resulting metabolites that retain the chiral centre in animals and plants was not investigated in the studies assessed in this MLR review. However, the possible impact of each individual mandipropamid enantiomer was considered acceptable due to the high margin of safety observed in the consumer risk assessment.

\section{Conclusions}

The metabolism of mandipropamid in fruits and leafy vegetables is similar. In roots the metabolism differs from fruits and leafy vegetables, since metabolite SYN 500003 was detected at significant levels. The residue definition for fruits and leafy vegetables is proposed as follows: mandipropamid (any ratio of constituent isomers). For roots the following residue definition for risk assessments is proposed: sum of mandipropamid and SYN 500003. This residue definition is tentative, pending on the submission of toxicological information on SYN 500003. A residue definition for enforcement for all crops under review is proposed as mandipropamid (any ratio of constituent isomers). A validated analytical method for all plant matrices with a LOQ of $0.01 \mathrm{mg} / \mathrm{kg}$ is available.

The data on metabolism and distribution of mandipropamid in rotational crops indicated that the metabolism in rotational crops is similar to the pathway observed in primary crops. Significant residues are not expected in rotational crops.

Mandipropamid was stable to hydrolysis under standard conditions of pasteurisation, baking/ brewing/boiling and sterilisation. Studies investigating the magnitude of residues in several processed commodities of tomatoes, grapes, potatoes and hops are available.

The available data are considered sufficient to derive appropriate MRL proposals as well as risk assessment values for all crops under review, apart from root crops since toxicological information on the metabolite SYN 500003 is needed.

Studies investigating the metabolism in livestock were conducted on lactating goats and laying hens. Since the calculated dietary burdens for all groups of livestock were found to be below the trigger value of $0.1 \mathrm{mg} / \mathrm{kg} \mathrm{DM}$, further investigation of residues as well as the setting of MRLs in commodities of animal origin is unnecessary.

Chronic consumer exposure resulting from the authorised uses reported in the framework of this review was calculated using revision 2 of the EFSA PRIMo. The relevant conversion factor was derived for root crops. The highest chronic exposure was calculated for FR toddler representing $2.8 \%$ of the ADI. Apart from the MRLs evaluated in the framework of this review, internationally recommended CXLs have also been established for mandipropamid. Additional calculations of the consumer exposure, considering these CXLS, were therefore carried out. The highest chronic exposure was calculated for NL children representing $5.0 \%$ of the ADI.

\section{Recommendations}

MRL recommendations were derived in compliance with the decision tree reported in Appendix $E$ of the reasoned opinion (see Table 2). All MRL values listed as 'Recommended' in the table are sufficiently supported by data and are therefore proposed for inclusion in Annex II to the Regulation.

For potatoes, although the number of residue trials reported is compliant with the data requirements, only tentative MRL and risk assessment values could be derived by EFSA and the following data gaps were identified:

- Toxicological information on the metabolite SYN 500003 is required (data gap relevant for potatoes, onions and spring onions). 
It is highlighted, however, that some of the MRLs derived result from a GAP in one climatic zone only, whereas other GAPs reported by the RMS were not fully supported by data. EFSA therefore identified the following data gaps which are not expected to impact on the validity of the MRLs derived but which might have an impact on national authorisations:

- Five additional residue trials supporting the northern outdoor GAP on tomatoes are required;

- Four residue trials supporting the northern outdoor GAP on courgettes are required.

If the above reported data gaps are not addressed in the future, MS are recommended to withdraw or modify the relevant authorisations at the national level.

A minor deficiency was identified in the assessment but this deficiency is not expected to impact either on the validity of the MRL derived or on the national authorisation. The following data are therefore considered desirable but not essential:

- One additional residue trial supporting the southern outdoor GAP on courgettes is required.

Table 2: Summary table

\begin{tabular}{l|l|c|c|c|c}
\hline $\begin{array}{l}\text { Code } \\
\text { number }\end{array}$ & Commodity & $\begin{array}{c}\text { Existing EU } \\
\text { MRL } \\
(\mathbf{m g} / \mathbf{k g})\end{array}$ & $\begin{array}{c}\text { Existing } \\
\mathbf{C X L} \\
(\mathbf{m g} / \mathbf{k g})\end{array}$ & $\begin{array}{c}\text { MRL } \\
(\mathbf{m g} / \mathbf{k g})\end{array}$ & Comment \\
\hline
\end{tabular}

\begin{tabular}{|c|c|c|c|c|c|}
\hline \multicolumn{6}{|c|}{$\begin{array}{l}\text { Enforcement residue definition (existing): mandipropamid (sum of isomers) } \\
\text { Enforcement residue definition (proposed): mandipropamid (any ratio of constituent isomers) }\end{array}$} \\
\hline 151010 & Table grapes & 2 & 2 & 2 & Recommended $^{(a)}$ \\
\hline 151020 & Wine grapes & 2 & 2 & 2 & Recommended $^{(a)}$ \\
\hline 211000 & Potatoes & $0.01 *$ & $0.01 *$ & $0.01 *$ & Further consideration needed ${ }^{(b)}$ \\
\hline 220020 & Onions & 0.1 & 0.1 & 0.1 & Further consideration needed ${ }^{(c)}$ \\
\hline 220040 & Spring onions & 7 & 7 & 7 & Further consideration needed ${ }^{(\mathrm{c})}$ \\
\hline 231010 & Tomatoes & 3 & 0.3 & 3 & Recommended $^{(d)}$ \\
\hline 231020 & Peppers & 1 & 1 & 1 & Recommended $^{(\mathrm{e})}$ \\
\hline 231030 & Aubergines/eggplants & 1 & - & 3 & Recommended $^{(f)}$ \\
\hline 232010 & Cucumbers & 0.2 & 0.2 & 0.2 & Recommended $^{(a)}$ \\
\hline 232030 & Courgettes & 0.2 & 0.2 & 0.2 & Recommended $^{(a)}$ \\
\hline 233010 & Melons & 0.5 & 0.5 & 0.5 & Recommended $^{(a)}$ \\
\hline 233020 & Pumpkins & 0.3 & - & 0.3 & Recommended $^{(f)}$ \\
\hline 241010 & Broccoli & 2 & 2 & 2 & Recommended $^{(e)}$ \\
\hline 242020 & Head cabbage & 3 & 3 & 3 & Recommended $^{(e)}$ \\
\hline 243010 & Chinese cabbage & 25 & 25 & 25 & Recommended $^{(e)}$ \\
\hline 243020 & Kale & 25 & 25 & 25 & Recommended $^{(e)}$ \\
\hline 251010 & $\begin{array}{l}\text { Lamb's lettuces/corn } \\
\text { salads }\end{array}$ & 25 & 25 & 25 & Recommended $^{(\mathrm{a})}$ \\
\hline 251020 & Lettuces & 25 & 25 & 25 & Recommended $^{(a)}$ \\
\hline 251030 & $\begin{array}{l}\text { Escaroles/broad-leaved } \\
\text { endives }\end{array}$ & 25 & 25 & 25 & Recommended $^{(\mathrm{a})}$ \\
\hline 251040 & $\begin{array}{l}\text { Cresses and other } \\
\text { sprouts and shoots }\end{array}$ & 25 & 25 & 25 & Recommended $^{(a)}$ \\
\hline 251050 & Land cresses & 25 & 25 & 25 & Recommended $^{(a)}$ \\
\hline 251060 & Roman rocket/rucola & 25 & 25 & 25 & Recommended $^{(a)}$ \\
\hline 251070 & Red mustards & 25 & 25 & 25 & Recommended $^{(a)}$ \\
\hline 251080 & $\begin{array}{l}\text { Baby leaf crops } \\
\text { (including brassica } \\
\text { species) }\end{array}$ & 25 & 25 & 25 & Recommended $^{(\mathrm{a})}$ \\
\hline 252010 & Spinaches & 25 & 25 & 25 & Recommended $^{(a)}$ \\
\hline 252020 & Purslanes & 25 & 25 & 25 & Recommended $^{(a)}$ \\
\hline 252030 & Chards/beet leaves & 25 & 25 & 25 & Recommended $^{(a)}$ \\
\hline
\end{tabular}




\begin{tabular}{|c|c|c|c|c|c|}
\hline \multirow[b]{2}{*}{$\begin{array}{l}\text { Code } \\
\text { number }\end{array}$} & \multirow[b]{2}{*}{ Commodity } & \multirow{2}{*}{$\begin{array}{c}\text { Existing EU } \\
\text { MRL } \\
(\mathbf{m g} / \mathbf{k g})\end{array}$} & \multirow{2}{*}{$\begin{array}{c}\text { Existing } \\
\text { CXL } \\
\text { (mg/kg) }\end{array}$} & \multicolumn{2}{|r|}{ Outcome of the review } \\
\hline & & & & $\begin{array}{c}\text { MRL } \\
(\mathrm{mg} / \mathrm{kg})\end{array}$ & Comment \\
\hline 253000 & $\begin{array}{l}\text { Vine leaves (grape } \\
\text { leaves) }\end{array}$ & $0.01 *$ & 25 & 25 & Recommended $^{(\mathrm{e})}$ \\
\hline 254000 & Water cress & 25 & 25 & 25 & Recommended $^{(e)}$ \\
\hline 255000 & Witloof & $0.01 *$ & 25 & 25 & Recommended $^{(e)}$ \\
\hline 256010 & Chervil & 10 & 25 & 25 & Recommended $^{(a)}$ \\
\hline 256020 & Chives & 10 & - & 15 & Recommended $^{(f)}$ \\
\hline 256030 & Celery leaves & 10 & - & 15 & Recommended $^{(f)}$ \\
\hline 256040 & Parsley & 10 & - & 15 & Recommended $^{(f)}$ \\
\hline 256050 & Sage & 10 & - & 15 & Recommended $^{(\mathrm{f})}$ \\
\hline 256060 & Rosemary & 10 & - & 15 & Recommended $^{(\mathrm{f})}$ \\
\hline 256070 & Thyme & 10 & - & 15 & Recommended $^{(\mathrm{f})}$ \\
\hline 256080 & Basil and edible flowers & 10 & - & 15 & Recommended $^{(f)}$ \\
\hline 256090 & Laurel/bay leave & 10 & - & 15 & Recommended $^{(f)}$ \\
\hline 256100 & Tarragon & 10 & - & 15 & Recommended $^{(\mathrm{f})}$ \\
\hline 270030 & Celery & 20 & 20 & 20 & Recommended $^{(e)}$ \\
\hline 700000 & Hops & 90 & 90 & 90 & Recommended $^{(\mathrm{d})}$ \\
\hline- & $\begin{array}{l}\text { Other commodities of } \\
\text { plant/animal origin }\end{array}$ & $\begin{array}{l}\text { See Reg. (EU) } \\
2015 / 845\end{array}$ & - & - & Further consideration needed $^{(\mathrm{g})}$ \\
\hline
\end{tabular}

MRL: maximum residue level; CXL: codex maximum residue limit.

*: Indicates that the MRL is set at the limit of quantification.

(a): MRL is derived from the existing CXL, which is supported by data and for which no risk to consumers is identified; GAP evaluated at the EU level, which is also fully supported by data, leads to a lower MRL (combination G-VII in Appendix E).

(b): Tentative MRL is derived from a GAP evaluated at the EU level, which is not fully supported by data but for which no risk to consumers was identified (assuming the existing residue definition); existing CXL is covered by the tentative MRL (combination E-III in Appendix E).

(c): MRL is derived from the existing CXL, which is not sufficiently supported by data but for which no risk to consumers is identified (assuming the existing residue definition); there are no relevant authorisations or import tolerances reported at the EU level (combination A-V in Appendix E).

(d): MRL is derived from a GAP evaluated at the EU level, which is fully supported by data and for which no risk to consumers is identified; existing CXL is covered by the recommended MRL (combination G-III in Appendix E).

(e): MRL is derived from the existing CXL, which is supported by data and for which no risk to consumers is identified; there are no relevant authorisations or import tolerances reported at the EU level (combination A-VII in Appendix E).

(f): MRL is derived from a GAP evaluated at the EU level, which is fully supported by data and for which no risk to consumers is identified; no CXL is available (combination G-I in Appendix E).

(g): There are no relevant authorisations or import tolerances reported at the EU level; no CXL is available. Either a specific LOQ or the default MRL of $0.01 \mathrm{mg} / \mathrm{kg}$ may be considered (combination A-I in Appendix E).

\section{References}

Austria, 2006. Draft Assessment Report (DAR) on the active substance mandipropamid prepared by the rapporteur Member State Austria in the framework of Directive 91/414/EEC, November 2006. Available online: www.efsa.europa.eu

Austria, 2012. Final Addendum to Draft Assessment Report on mandipropamid, compiled by EFSA, July 2012. Available online: www.efsa.europa.eu

Austria, 2013. Evaluation report prepared under Article 12.1 of Regulation (EC) No 396/2005. Review of the existing MRLs for mandipropamid, May 2013. Available online: www.efsa.europa.eu

Austria, 2017. Evaluation report prepared under Article 12 of Regulation (EC) No 396/2005. Authorised uses to be considered for the review of the existing MRLs for mandipropamid, August 2017. Available online: www.efsa.europa.eu

Belgium, 2017. Evaluation report prepared under Article 12 of Regulation (EC) No 396/2005. Authorised uses to be considered for the review of the existing MRLs for mandipropamid, October 2017. Available online: www.efsa.europa.eu

EFSA (European Food Safety Authority), 2007. Reasoned opinion on the potential chronic and acute risk to consumers' health arising from proposed temporary EU MRLs. EFSA Journal 2007;5(3):32r, 1141 pp. https://doi. org/10.2903/j.efsa.2007.32r 
EFSA (European Food Safety Authority), 2009a. Reasoned opinion on the modification of the existing MRLs for mandipropamid in several leafy vegetables. EFSA Journal 2009;7(1):229r, 25 pp. https://doi.org/10.2903/j.efsa. 2009.229r

EFSA (European Food Safety Authority), 2009b. Reasoned opinion on the modification of the existing MRL for mandipropamid in garden cress. EFSA Journal 2009;7(9):1311, 22 pp. https://doi.org/10.2903/j.efsa.2009. 1311

EFSA (European Food Safety Authority), 2011. Reasoned opinion on the modification of the current MRL for mandipropamid in hops. EFSA Journal 2011;9(2):2013, 22 pp. https://doi.org/10.2903/j.efsa.2011.2013

EFSA (European Food Safety Authority), 2012. Conclusion on the peer review of the pesticide risk assessment of the active substance mandipropamid. EFSA Journal 2012;10(11):2935, 76 pp. https://doi.org/10.2903/j.efsa. 2012.2935

EFSA (European Food Safety Authority), 2013. Reasoned opinion on the modification of the existing MRL for mandipropamid in tomato. EFSA Journal 2013;11(11):3466, 23 pp. https://doi.org/10.2903/j.efsa.2013.3466

EFSA (European Food Safety Authority), 2018a. Completeness check report on the review of the existing MRLs of mandipropamid prepared by EFSA in the framework of Article 12 of Regulation (EC) No 396/2005, 7 March 2018. Available online: www.efsa.europa.eu

EFSA (European Food Safety Authority), 2018b. Member States consultation report on the review of the existing MRLs of mandipropamid prepared by EFSA in the framework of Article 12 of Regulation (EC) No 396/2005, 24 April 2018. Available online: www.efsa.europa.eu

EURL (European Union Reference Laboratories for Pesticide Residues), 2017. Evaluation report prepared under Article 12 of Regulation (EC) No 396/2005. Analytical methods validated by the EURLs and overall capability of official laboratories to be considered for the review of the existing MRLs for mandipropamid. October 2017. Available online: www.efsa.europa.eu

European Commission, 1997a. Appendix A. Metabolism and distribution in plants. 7028/IV/95-rev., 22 July 1996.

European Commission, 1997b. Appendix B. General recommendations for the design, preparation and realization of residue trials. Annex 2. Classification of (minor) crops not listed in the Appendix of Council Directive 90/642/EEC. 7029/VI/95-rev. 6, 22 July 1997.

European Commission, 1997c. Appendix C. Testing of plant protection products in rotational crops. 7524/VI/95rev. 2, 22 July 1997.

European Commission, 1997d. Appendix E. Processing studies. 7035/VI/95-rev. 5, 22 July 1997.

European Commission, 1997e. Appendix F. Metabolism and distribution in domestic animals. 7030/VI/95-rev. 3, 22 July 1997.

European Commission, 1997f. Appendix H. Storage stability of residue samples. 7032/VI/95-rev. 5, 22 July 1997.

European Commission, 1997g. Appendix I. Calculation of maximum residue level and safety intervals.7039/VI/95 22 July 1997. As amended by the document: classes to be used for the setting of EU pesticide maximum residue levels (MRLS). SANCO 10634/2010, finalised in the Standing Committee on the Food Chain and Animal Health at its meeting of 23-24 March 2010.

European Commission, 2000. Residue analytical methods. For pre-registration data requirement for Annex II (part A, section 4) and Annex III (part A, section 5 of Directive 91/414. SANCO/3029/99-rev. 4.

European Commission, 2010a. Classes to be used for the setting of EU pesticide Maximum Residue Levels (MRLs). SANCO 10634/2010-rev. 0, Finalised in the Standing Committee on the Food Chain and Animal Health at its meeting of 23-24 March 2010.

European Commission, 2010b. Residue analytical methods. For post-registration control. SANCO/825/00-rev. 8.1, 16 November 2010.

European Commission, 2017. Appendix D. Guidelines on comparability, extrapolation, group tolerances and data requirements for setting MRLs. 7525/VI/95-rev.10.3, June 2017

FAO (Food and Agriculture Organization of the United Nations), 2008. Mandipropamid. In: Pesticide residues in food - 2008. Report of the Joint Meeting of the FAO Panel of Experts on Pesticide Residues in Food and the Environment and the WHO Core Assessment Group on Pesticide Residues. FAO Plant Production and Protection Paper 193.

FAO (Food and Agriculture Organization of the United Nations), 2009. Submission and evaluation of pesticide residues data for the estimation of Maximum Residue Levels in food and feed. Pesticide Residues. 2nd Ed. FAO Plant Production and Protection Paper 197, 264 pp.

FAO (Food and Agriculture Organization of the United Nations), 2013. Mandipropamid. In: Pesticide residues in food - 2013. Report of the Joint Meeting of the FAO Panel of Experts on Pesticide Residues in Food and the Environment and the WHO Core Assessment Group on Pesticide Residues. FAO Plant Production and Protection Paper 219.

France, 2017. Evaluation report prepared under Article 12 of Regulation (EC) No 396/2005. Authorised uses to be considered for the review of the existing MRLs for mandipropamid, October 2017. Available online: www.efsa.europa.eu

Germany, 2017. Evaluation report prepared under Article 12 of Regulation (EC) No 396/2005. Authorised uses to be considered for the review of the existing MRLs for mandipropamid, September 2017. Available online: www.efsa.europa.eu 
Greece, 2017. Evaluation report prepared under Article 12 of Regulation (EC) No 396/2005. Review of the existing MRLs for mandipropamid, October 2017. Available online: www.efsa.europa.eu

Italy, 2017. Evaluation report prepared under Article 12 of Regulation (EC) No 396/2005. Authorised uses to be considered for the review of the existing MRLs for mandipropamid, October 2017. Available online: www.efsa.europa.eu

Netherlands, 2017. Evaluation report prepared under Article 12 of Regulation (EC) No 396/2005. Authorised uses to be considered for the review of the existing MRLs for mandipropamid, October 2017. Available online: www.efsa.europa.eu

OECD (Organisation for Economic Co-operation and Development), 2011. OECD MRL calculator: spreadsheet for single data set and spreadsheet for multiple data set, 2 March 2011. In: Pesticide Publications/Publications on Pesticide Residues. Available online: http://www.oecd.org

OECD (Organisation for Economic Co-operation and Development), 2013. Guidance document on residues in livestock. In: Series on Pesticides No 73. ENV/JM/MONO(2013)8, 04 September 2013.

Portugal, 2017. Evaluation report prepared under Article 12 of Regulation (EC) No 396/2005. Authorised uses to be considered for the review of the existing MRLs for mandipropamid, October 2017, amended in December 2017. Available online: www.efsa.europa.eu

Spain, 2017. Evaluation report prepared under Article 12 of Regulation (EC) No 396/2005. Authorised uses to be considered for the review of the existing MRLs for mandipropamid, October 2017. Available online: www.efsa.europa.eu

Sweden, 2017. Evaluation report prepared under Article 12 of Regulation (EC) No 396/2005. Authorised uses to be considered for the review of the existing MRLs for mandipropamid, November 2017. Available online: www.efsa.europa.eu

United Kingdom, 2017. Evaluation report prepared under Article 12 of Regulation (EC) No 396/2005. Authorised uses to be considered for the review of the existing MRLs for mandipropamid, October 2017. Available online: www.efsa.europa.eu

\section{Abbreviations}

\begin{tabular}{|c|c|}
\hline a.i. & active ingredient \\
\hline a.s. & active substance \\
\hline ADI & acceptable daily intake \\
\hline ARfD & acute reference dose \\
\hline $\mathrm{BBCH}$ & growth stages of mono- and dicotyledonous plants \\
\hline bw & body weight \\
\hline CAC & Codex Alimentarius Commission \\
\hline CF & conversion factor for enforcement residue definition to risk assessment residue definition \\
\hline $\mathrm{XL}$ & codex maximum residue limit \\
\hline AR & draft assessment report \\
\hline AT & days after treatment \\
\hline M & dry matter \\
\hline DT $_{90}$ & period required for $90 \%$ dissipation (define method of estimation) \\
\hline & European Commission \\
\hline FSA & European Food Safety Authority \\
\hline eq & residue expressed as a.s. equivalent \\
\hline URLS & European Union Reference Laboratories for Pesticide Residues (former CRLs) \\
\hline FAO & Food and Agriculture Organization of the United Nations \\
\hline AP & Good Agricultural Practice \\
\hline HR & highest residue \\
\hline EDI & international estimated daily intake \\
\hline IESTI & international estimated short-term intake \\
\hline ILV & independent laboratory validation \\
\hline ISO & International Organisation for Standardization \\
\hline IUPAC & International Union of Pure and Applied Chemistry \\
\hline JMPR & $\begin{array}{l}\text { Joint Meeting of the FAO Panel of Experts on Pesticide Residues in Food and the } \\
\text { Environment and the WHO Expert Group on Pesticide Residues (Joint Meeting on Pesticide } \\
\text { Residues) }\end{array}$ \\
\hline LOQ & limit of quantification \\
\hline & maximum residue level \\
\hline & Member States \\
\hline & spectrometry detector \\
\hline
\end{tabular}


NEU northern European Union

OECD Organisation for Economic Co-operation and Development

PBI plant back interval

PF processing factor

PHI pre-harvest interval

PRIMo (EFSA) Pesticide Residues Intake Model

PROFile (EFSA) Pesticide Residues Overview File

RA risk assessment

$\mathrm{RD} \quad$ residue definition

RAC raw agricultural commodity

RMS rapporteur Member State

SANCO Directorate-General for Health and Consumers

SC suspension concentrate

SEU Southern European Union

SMILES simplified molecular-input line-entry system

STMR supervised trials median residue

TRR total radioactive residue

WG water dispersible granule

WHO World Health Organization 


\section{Appendix A - Summary of authorised uses considered for the review of MRLs}

\section{A.1. Authorised uses in northern outdoor EU}

\begin{tabular}{|c|c|c|c|c|c|c|c|c|c|c|c|c|c|c|}
\hline \multirow[b]{2}{*}{$\begin{array}{l}\text { Crop } \\
\text { and/or } \\
\text { situation }\end{array}$} & \multirow{2}{*}{$\begin{array}{l}\text { NEU, SEU, } \\
\text { MS } \\
\text { or } \\
\text { country }\end{array}$} & \multirow{2}{*}{$\begin{array}{l}\mathbf{F} \\
\mathbf{G} \\
\text { or } \\
\mathbf{I}^{(\mathbf{a})}\end{array}$} & \multirow[b]{2}{*}{$\begin{array}{l}\text { Pests or } \\
\text { Group of pests } \\
\text { controlled }\end{array}$} & \multicolumn{2}{|c|}{ Preparation } & \multicolumn{4}{|c|}{ Application } & \multicolumn{3}{|c|}{$\begin{array}{c}\text { Application rate per } \\
\text { treatment }\end{array}$} & \multirow[b]{2}{*}{$\begin{array}{c}\text { PHI } \\
\text { (days) }^{(d)}\end{array}$} & \multirow[b]{2}{*}{ Remarks } \\
\hline & & & & Type $^{(b)}$ & $\begin{array}{l}\text { Conc. } \\
\text { a.s. }\end{array}$ & $\begin{array}{l}\text { Method } \\
\text { kind }\end{array}$ & $\begin{array}{l}\text { Range of } \\
\text { growth } \\
\text { stages \& } \\
\text { season (c) }^{\text {(c) }}\end{array}$ & $\begin{array}{c}\text { Number } \\
\text { min- } \\
\text { max }\end{array}$ & $\begin{array}{l}\text { Interval } \\
\text { between } \\
\text { application } \\
\text { (min) }\end{array}$ & $\begin{array}{c}\text { g } \\
\text { a.s./hL } \\
\text { min-- } \\
\max \end{array}$ & $\begin{array}{l}\text { Water } \\
\text { L/ha } \\
\text { min- } \\
\text { max }\end{array}$ & $\begin{array}{l}\text { g } \\
\text { a.s./ha } \\
\text { min- } \\
\text { max }\end{array}$ & & \\
\hline Table grapes & AT & $\mathrm{F}$ & $\begin{array}{l}\text { Plasmopara } \\
\text { viticola }\end{array}$ & WG & $250 \mathrm{~g} / \mathrm{kg}$ & $\begin{array}{l}\text { Foliar } \\
\text { treatment } \\
\text { - spraying }\end{array}$ & 13 to 85 & 3 & 8 & - & - & $\begin{array}{l}125 \mathrm{~g} \\
\text { a.i./ha }\end{array}$ & 21 & \\
\hline Wine grapes & $\mathrm{CZ}$ & $\mathrm{F}$ & & WG & $50 \mathrm{~g} / \mathrm{kg}$ & $\begin{array}{l}\text { Foliar } \\
\text { treatment } \\
\text { - spraying }\end{array}$ & n.a. to 81 & 4 & 10 & - & - & $\begin{array}{l}130 \mathrm{~g} \\
\text { a.i./ha }\end{array}$ & 21 & \\
\hline Potatoes & $\mathrm{NL}$ & $\mathrm{F}$ & $\begin{array}{l}\text { Phytophthora } \\
\text { infestans }\end{array}$ & SC & $250 \mathrm{~g} / \mathrm{L}$ & $\begin{array}{l}\text { Foliar } \\
\text { treatment } \\
\text { - spraying }\end{array}$ & 31 to 90 & 6 & 5 & - & - & $\begin{array}{l}150 \mathrm{~g} \\
\text { a.i./ha }\end{array}$ & 3 & \\
\hline Tomatoes & $\mathrm{DE}$ & $\mathrm{F}$ & $\begin{array}{l}\text { Phytophthora } \\
\text { infestans }\end{array}$ & $\mathrm{SC}$ & $250 \mathrm{~g} / \mathrm{L}$ & $\begin{array}{l}\text { Foliar } \\
\text { treatment } \\
\text { - spraying }\end{array}$ & n.a. & 4 & 7 & - & - & $\begin{array}{l}150 \mathrm{~g} \\
\text { a.i./ha }\end{array}$ & 3 & \\
\hline Courgettes & IE & $\mathrm{F}$ & & SC & $250 \mathrm{~g} / \mathrm{L}$ & $\begin{array}{l}\text { Foliar } \\
\text { treatment } \\
\text { - spraying }\end{array}$ & n.a. & 2 & & - & - & $\begin{array}{l}150 \mathrm{~g} \\
\text { a.i./ha }\end{array}$ & 7 & \\
\hline $\begin{array}{l}\text { Lamb's } \\
\text { lettuces }\end{array}$ & $\begin{array}{l}\text { UK, DE, AT, } \\
\text { SE }\end{array}$ & $\mathrm{F}$ & Peronosporaceae & SC & $250 \mathrm{~g} / \mathrm{L}$ & $\begin{array}{l}\text { Foliar } \\
\text { treatment } \\
\text { - spraying }\end{array}$ & n.a. & 2 & & - & - & $\begin{array}{l}150 \mathrm{~g} \\
\text { a.i./ha }\end{array}$ & 7 & \\
\hline Lettuces & $\begin{array}{l}\mathrm{IE}, \mathrm{CZ}, \mathrm{BE} \\
\mathrm{FI}, \mathrm{DE}, \mathrm{SE}\end{array}$ & $\mathrm{F}$ & & SC & $250 \mathrm{~g} / \mathrm{L}$ & $\begin{array}{l}\text { Foliar } \\
\text { treatment } \\
\text { - spraying }\end{array}$ & n.a. & 2 & & - & - & $\begin{array}{l}150 \mathrm{~g} \\
\text { a.i./ha }\end{array}$ & 7 & \\
\hline Escaroles & $\mathrm{DE}$ & $\mathrm{F}$ & Peronosporaceae & $\mathrm{SC}$ & $250 \mathrm{~g} / \mathrm{L}$ & $\begin{array}{l}\text { Foliar } \\
\text { treatment } \\
\text { - spraying }\end{array}$ & n.a. & 2 & 7 & - & - & $\begin{array}{l}150 \mathrm{~g} \\
\text { a.i./ha }\end{array}$ & 7 & \\
\hline Cresses & $\begin{array}{l}\text { UK, DE, AT, } \\
\text { SE }\end{array}$ & $\mathrm{F}$ & & SC & $250 \mathrm{~g} / \mathrm{L}$ & $\begin{array}{l}\text { Foliar } \\
\text { treatment } \\
\text { - spraying }\end{array}$ & n.a. & 2 & 7 & - & - & $\begin{array}{l}150 \mathrm{~g} \\
\text { a.i./ha }\end{array}$ & 7 & \\
\hline
\end{tabular}




\begin{tabular}{|c|c|c|c|c|c|c|c|c|c|c|c|c|c|c|}
\hline \multirow[b]{2}{*}{$\begin{array}{l}\text { Crop } \\
\text { and/or } \\
\text { situation }\end{array}$} & \multirow{2}{*}{$\begin{array}{l}\text { NEU, SEU, } \\
\text { MS } \\
\text { or } \\
\text { country }\end{array}$} & \multirow{2}{*}{$\begin{array}{l}\mathbf{F} \\
\mathbf{G} \\
\text { or } \\
\mathbf{I}^{(a)}\end{array}$} & \multirow[b]{2}{*}{$\begin{array}{l}\text { Pests or } \\
\text { Group of pests } \\
\text { controlled }\end{array}$} & \multicolumn{2}{|c|}{ Preparation } & \multicolumn{4}{|c|}{ Application } & \multicolumn{3}{|c|}{$\begin{array}{c}\text { Application rate per } \\
\text { treatment }\end{array}$} & \multirow[b]{2}{*}{$\begin{array}{c}\text { PHI } \\
\text { (days) }^{(d)}\end{array}$} & \multirow[b]{2}{*}{ Remarks } \\
\hline & & & & Type $^{(b)}$ & $\begin{array}{l}\text { Conc. } \\
\text { a.s. }\end{array}$ & $\begin{array}{l}\text { Method } \\
\text { kind }\end{array}$ & $\begin{array}{l}\text { Range of } \\
\text { growth } \\
\text { stages \& } \\
\text { season }^{(c)}\end{array}$ & $\begin{array}{c}\text { Number } \\
\text { min- } \\
\text { max }\end{array}$ & $\begin{array}{l}\text { Interval } \\
\text { between } \\
\text { application } \\
\text { (min) }\end{array}$ & $\begin{array}{c}\mathbf{g} \\
\text { a.s./hL } \\
\min - \\
\max \end{array}$ & $\begin{array}{l}\text { Water } \\
\text { L/ha } \\
\text { min- } \\
\text { max }\end{array}$ & $\begin{array}{l}\text { g } \\
\text { a.s./ha } \\
\text { min- } \\
\text { max }\end{array}$ & & \\
\hline Land cresses & UK, SE & $\mathrm{F}$ & & SC & $250 \mathrm{~g} / \mathrm{L}$ & \begin{tabular}{|l|} 
Foliar \\
treatment \\
- spraying
\end{tabular} & n.a. & 2 & & - & - & $\begin{array}{l}150 \mathrm{~g} \\
\text { a.i./ha }\end{array}$ & 7 & \\
\hline Roman rocket & $\mathrm{DE}, \mathrm{BE}, \mathrm{SE}$ & $\mathrm{F}$ & Peronosporaceae & SC & $250 \mathrm{~g} / \mathrm{L}$ & $\begin{array}{l}\text { Foliar } \\
\text { treatment } \\
\text { - spraying }\end{array}$ & n.a. & 2 & 7 & - & - & $\begin{array}{l}150 \mathrm{~g} \\
\text { a.i./ha }\end{array}$ & 7 & \\
\hline Red mustards & DE, SE & $\mathrm{F}$ & & SC & $250 \mathrm{~g} / \mathrm{L}$ & \begin{tabular}{|l|} 
Foliar \\
treatment \\
- spraying
\end{tabular} & n.a. & 2 & & - & - & $\begin{array}{l}150 \mathrm{~g} \\
\text { a.i./ha }\end{array}$ & 7 & \\
\hline $\begin{array}{l}\text { Baby leaf } \\
\text { crops }\end{array}$ & UK, DE, SE & $\mathrm{F}$ & & SC & $250 \mathrm{~g} / \mathrm{L}$ & \begin{tabular}{|l} 
Foliar \\
treatment \\
- spraying
\end{tabular} & n.a. & 2 & & - & - & $\begin{array}{l}150 \mathrm{~g} \\
\text { a.i./ha }\end{array}$ & 7 & \\
\hline Spinaches & $\mathrm{DE}, \mathrm{SE}$ & $\mathrm{F}$ & & SC & $250 \mathrm{~g} / \mathrm{L}$ & \begin{tabular}{|l|} 
Foliar \\
treatment \\
- spraying
\end{tabular} & n.a. & 2 & 7 & - & - & $\begin{array}{l}150 \mathrm{~g} \\
\text { a.i./ha }\end{array}$ & 7 & \\
\hline Purslanes & $\begin{array}{l}\text { UK, DE, AT, } \\
\text { SE }\end{array}$ & $\mathrm{F}$ & $\begin{array}{l}\text { Peronospora } \\
\text { farinosa f.sp. } \\
\text { Spinaciae }\end{array}$ & SC & $250 \mathrm{~g} / \mathrm{L}$ & \begin{tabular}{|l|} 
Foliar \\
treatment \\
- spraying
\end{tabular} & n.a. & 2 & & - & - & $\begin{array}{l}150 \mathrm{~g} \\
\text { a.i./ha }\end{array}$ & 7 & \\
\hline Chards & $\mathrm{DE}, \mathrm{SE}$ & $\mathrm{F}$ & & SC & $250 \mathrm{~g} / \mathrm{L}$ & \begin{tabular}{|l|} 
Foliar \\
treatment \\
- spraying
\end{tabular} & n.a. & 2 & & - & - & $\begin{array}{l}150 \mathrm{~g} \\
\text { a.i./ha }\end{array}$ & 7 & \\
\hline Chervil & $\mathrm{IE}, \mathrm{BE}, \mathrm{DE}$ & $\mathrm{F}$ & & SC & $250 \mathrm{~g} / \mathrm{L}$ & $\begin{array}{l}\text { Foliar } \\
\text { treatment } \\
\text { - spraying }\end{array}$ & n.a. & 2 & & - & - & $\begin{array}{l}150 \mathrm{~g} \\
\text { a.i./ha }\end{array}$ & 7 & \\
\hline Chives & $\mathrm{IE}, \mathrm{DE}$ & $\mathrm{F}$ & & SC & $250 \mathrm{~g} / \mathrm{L}$ & \begin{tabular}{|l|} 
Foliar \\
treatment \\
- spraying
\end{tabular} & n.a. & 2 & & - & - & $\begin{array}{l}150 \mathrm{~g} \\
\text { a.i./ha }\end{array}$ & 7 & \\
\hline Celery leaves & $\mathrm{IE}, \mathrm{BE}, \mathrm{DE}$ & $\mathrm{F}$ & & SC & $250 \mathrm{~g} / \mathrm{L}$ & $\begin{array}{l}\text { Foliar } \\
\text { treatment } \\
\text { - spraying }\end{array}$ & n.a. & 2 & & - & - & $\begin{array}{l}150 \mathrm{~g} \\
\text { a.i./ha }\end{array}$ & 7 & \\
\hline
\end{tabular}




\begin{tabular}{|c|c|c|c|c|c|c|c|c|c|c|c|c|c|c|}
\hline \multirow[b]{2}{*}{$\begin{array}{l}\text { Crop } \\
\text { and/or } \\
\text { situation }\end{array}$} & \multirow{2}{*}{$\begin{array}{l}\text { NEU, SEU, } \\
\text { MS } \\
\text { or } \\
\text { country }\end{array}$} & \multirow{2}{*}{$\begin{array}{l}\text { F } \\
\text { G } \\
\text { or } \\
\mathbf{I}^{(a)}\end{array}$} & \multirow[b]{2}{*}{$\begin{array}{l}\text { Pests or } \\
\text { Group of pests } \\
\text { controlled }\end{array}$} & \multicolumn{2}{|c|}{ Preparation } & \multicolumn{4}{|c|}{ Application } & \multicolumn{3}{|c|}{$\begin{array}{c}\text { Application rate per } \\
\text { treatment }\end{array}$} & \multirow[b]{2}{*}{$\begin{array}{c}\text { PHI } \\
\text { (days) }^{(d)}\end{array}$} & \multirow[b]{2}{*}{ Remarks } \\
\hline & & & & Type $^{(b)}$ & $\begin{array}{l}\text { Conc. } \\
\text { a.s. }\end{array}$ & $\begin{array}{l}\text { Method } \\
\text { kind }\end{array}$ & $\begin{array}{l}\text { Range of } \\
\text { growth } \\
\text { stages \& } \\
\text { season (c) }^{\text {(c) }}\end{array}$ & $\begin{array}{c}\text { Number } \\
\text { min- } \\
\text { max }\end{array}$ & $\begin{array}{c}\text { Interval } \\
\text { between } \\
\text { application } \\
\text { (min) }\end{array}$ & $\begin{array}{c}\text { g } \\
\text { a.s./hL } \\
\text { min- } \\
\max \end{array}$ & $\begin{array}{l}\text { Water } \\
\text { L/ha } \\
\text { min- } \\
\text { max }\end{array}$ & $\begin{array}{l}\text { g } \\
\text { a.s./ha } \\
\text { min- } \\
\text { max }\end{array}$ & & \\
\hline Parsley & $\mathrm{IE}, \mathrm{BE}, \mathrm{DE}$ & $\mathrm{F}$ & & SC & $250 \mathrm{~g} / \mathrm{L}$ & $\begin{array}{l}\text { Foliar } \\
\text { treatment } \\
\text { - spraying }\end{array}$ & n.a. & 2 & & - & - & $\begin{array}{l}150 \mathrm{~g} \\
\text { a.i./ha }\end{array}$ & 7 & \\
\hline Sage & $\mathrm{IE}, \mathrm{BE}, \mathrm{DE}$ & $F$ & & SC & $250 \mathrm{~g} / \mathrm{L}$ & $\begin{array}{l}\text { Foliar } \\
\text { treatment } \\
\text { - spraying }\end{array}$ & n.a. & 2 & & - & - & $\begin{array}{l}150 \mathrm{~g} \\
\text { a.i./ha }\end{array}$ & 7 & \\
\hline Rosemary & $\mathrm{IE}, \mathrm{BE}, \mathrm{DE}$ & $F$ & & SC & $250 \mathrm{~g} / \mathrm{L}$ & $\begin{array}{l}\text { Foliar } \\
\text { treatment } \\
\text { - spraying }\end{array}$ & n.a. & 2 & & - & - & $\begin{array}{l}150 \mathrm{~g} \\
\text { a.i./ha }\end{array}$ & 7 & \\
\hline Thyme & $\mathrm{IE}, \mathrm{DE}$ & $F$ & & SC & $250 \mathrm{~g} / \mathrm{L}$ & $\begin{array}{l}\text { Foliar } \\
\text { treatment } \\
\text { - spraying }\end{array}$ & n.a. & 2 & & - & - & $\begin{array}{l}150 \mathrm{~g} \\
\text { a.i./ha }\end{array}$ & 7 & \\
\hline Basil & $\mathrm{IE}, \mathrm{BE}, \mathrm{DE}$ & $F$ & & SC & $250 \mathrm{~g} / \mathrm{L}$ & $\begin{array}{l}\text { Foliar } \\
\text { treatment } \\
\text { - spraying }\end{array}$ & n.a. & 2 & & - & - & $\begin{array}{l}150 \mathrm{~g} \\
\text { a.i./ha }\end{array}$ & 7 & \\
\hline Laurel & $\mathrm{IE}, \mathrm{DE}$ & $F$ & & SC & $250 \mathrm{~g} / \mathrm{L}$ & $\begin{array}{l}\text { Foliar } \\
\text { treatment } \\
\text { - spraying }\end{array}$ & n.a. & 2 & & - & - & $\begin{array}{l}150 \mathrm{~g} \\
\text { a.i./ha }\end{array}$ & 7 & \\
\hline Tarragon & $\mathrm{IE}, \mathrm{DE}$ & $\mathrm{F}$ & & SC & $250 \mathrm{~g} / \mathrm{L}$ & $\begin{array}{l}\text { Foliar } \\
\text { treatment } \\
\text { - spraying }\end{array}$ & n.a. & 2 & & - & - & $\begin{array}{l}150 \mathrm{~g} \\
\text { a.i./ha }\end{array}$ & 7 & \\
\hline Hops & $\mathrm{DE}, \mathrm{CZ}, \mathrm{BE}$ & $\mathrm{F}$ & $\begin{array}{l}\text { Spora humuli, } \\
\text { secondary } \\
\text { infection (Downy } \\
\text { mildew of hops) }\end{array}$ & SC & $250 \mathrm{~g} / \mathrm{L}$ & $\begin{array}{l}\text { Foliar } \\
\text { treatment } \\
\text { - spraying }\end{array}$ & 31 to 87 & 2 & 10 & - & - & $\begin{array}{l}400 \mathrm{~g} \\
\text { a.i.//ha }\end{array}$ & 14 & \\
\hline
\end{tabular}

a.i.: active ingredient, SC: suspension concentrate; WG: water dispersible granule; n.a.: not applicable.

(a): Outdoor or field use (F), greenhouse application (G) or indoor application (I).

(b): CropLife International Technical Monograph no 2, 6th Edition. Revised May 2008. Catalogue of pesticide.

(c): Growth stage range from first to last treatment (BBCH Monograph, Growth Stages of Plants, 1997, Blackwell, ISBN 3-8263-3152-4), including, where relevant, information on season at time of application.

(d): PHI - minimum pre-harvest interval. 


\section{A.2. Authorised uses in southern outdoor EU}

\begin{tabular}{|c|c|c|c|c|c|c|c|c|c|c|c|c|c|c|}
\hline \multirow[b]{2}{*}{$\begin{array}{l}\text { Crop } \\
\text { and/or } \\
\text { situation }\end{array}$} & \multirow[b]{2}{*}{$\begin{array}{l}\text { NEU, } \\
\text { SEU, MS } \\
\text { or } \\
\text { country }\end{array}$} & \multirow[b]{2}{*}{$\begin{array}{l}\mathbf{F} \\
\mathbf{G} \\
\text { or } \\
\mathbf{I}^{(a)}\end{array}$} & \multirow[b]{2}{*}{$\begin{array}{l}\text { Pests or } \\
\text { Group of pests } \\
\text { controlled }\end{array}$} & \multicolumn{2}{|c|}{ Preparation } & \multicolumn{4}{|c|}{ Application } & \multicolumn{3}{|c|}{$\begin{array}{c}\text { Application rate per } \\
\text { treatment }\end{array}$} & \multirow[b]{2}{*}{$\begin{array}{c}\text { PHI } \\
\text { (days) }^{(d)}\end{array}$} & \multirow[b]{2}{*}{ Remarks } \\
\hline & & & & Type $^{(b)}$ & $\begin{array}{l}\text { Conc. } \\
\text { a.s. }\end{array}$ & $\begin{array}{l}\text { Method } \\
\text { kind }\end{array}$ & $\begin{array}{l}\text { Range of } \\
\text { growth } \\
\text { stages \& } \\
\text { season (c) }^{\text {(c) }}\end{array}$ & $\begin{array}{c}\text { Number } \\
\text { min- } \\
\text { max }\end{array}$ & $\begin{array}{c}\text { Interval } \\
\text { between } \\
\text { application } \\
\text { (min) }\end{array}$ & $\begin{array}{c}\mathbf{g} \\
\text { a.s./hL } \\
\text { min- } \\
\max \end{array}$ & $\begin{array}{l}\text { Water } \\
\text { L/ha } \\
\text { min- } \\
\text { max }\end{array}$ & $\begin{array}{l}\text { g } \\
\text { a.s./ha } \\
\text { min- } \\
\text { max }\end{array}$ & & \\
\hline Table grapes & ES & $\mathrm{F}$ & Plasmopara viticola & WG & $50 \mathrm{~g} / \mathrm{kg}$ & $\begin{array}{l}\text { Foliar } \\
\text { treatment } \\
\text { - spraying }\end{array}$ & n.a. to 81 & 4 & 8 & - & - & $\begin{array}{l}150 \mathrm{~g} \\
\text { a.i./ha }\end{array}$ & 21 & \\
\hline Wine grapes & ES & $\mathrm{F}$ & Plasmopara viticola & WG & $50 \mathrm{~g} / \mathrm{kg}$ & $\begin{array}{l}\text { Foliar } \\
\text { treatment } \\
\text { - spraying }\end{array}$ & n.a. to 81 & 4 & 8 & - & - & $\begin{array}{l}150 \mathrm{~g} \\
\text { a.i./ha }\end{array}$ & 21 & \\
\hline Potatoes & $\mathrm{EL}$ & $\mathrm{F}$ & $\begin{array}{l}\text { Phytophthora } \\
\text { infestans }\end{array}$ & $\mathrm{SC}$ & $250 \mathrm{~g} / \mathrm{L}$ & $\begin{array}{l}\text { Foliar } \\
\text { treatment } \\
\text { - spraying }\end{array}$ & 31 to 91 & 6 & 7 & - & - & $\begin{array}{l}150 \mathrm{~g} \\
\text { a.i.//ha }\end{array}$ & 3 & \\
\hline Tomatoes & IT, EL, ES & $\mathrm{F}$ & $\begin{array}{l}\text { Phytophthora } \\
\text { infestans }\end{array}$ & $\mathrm{SC}$ & $250 \mathrm{~g} / \mathrm{L}$ & $\begin{array}{l}\text { Foliar } \\
\text { treatment } \\
\text { - spraying }\end{array}$ & n.a. & 4 & 7 & - & - & $\begin{array}{l}150 \mathrm{~g} \\
\text { a.i./ha }\end{array}$ & 3 & \\
\hline Courgettes & IT, ES & $\mathrm{F}$ & $\begin{array}{l}\text { Pseudoperonospora } \\
\text { cubensis }\end{array}$ & $\mathrm{SC}$ & $250 \mathrm{~g} / \mathrm{L}$ & $\begin{array}{l}\text { Foliar } \\
\text { treatment } \\
\text { - spraying }\end{array}$ & n.a. & 4 & 7 & - & - & $\begin{array}{l}150 \mathrm{~g} \\
\text { a.i./ha }\end{array}$ & 3 & \\
\hline Melons & IT, ES, EL & $\mathrm{F}$ & $\begin{array}{l}\text { Pseudoperonospora } \\
\text { cubensis }\end{array}$ & SC & $250 \mathrm{~g} / \mathrm{L}$ & $\begin{array}{l}\text { Foliar } \\
\text { treatment } \\
\text { - spraying }\end{array}$ & n.a. & 4 & 7 & - & - & $\begin{array}{l}150 \mathrm{~g} \\
\text { a.i./ha }\end{array}$ & 3 & \\
\hline Lettuces & IT, ES, EL & $\mathrm{F}$ & Bremia lactucae & $\mathrm{SC}$ & $250 \mathrm{~g} / \mathrm{L}$ & $\begin{array}{l}\text { Foliar } \\
\text { treatment } \\
\text { - spraying }\end{array}$ & n.a. & 2 & 7 & - & - & $\begin{array}{l}150 \mathrm{~g} \\
\text { a.i./ha }\end{array}$ & 7 & \\
\hline Escaroles & IT, PT & $\mathrm{F}$ & Bremia lactucae & SC & $250 \mathrm{~g} / \mathrm{L}$ & $\begin{array}{l}\text { Foliar } \\
\text { treatment } \\
\text { - spraying }\end{array}$ & n.a. & 2 & 7 & - & - & $\begin{array}{l}150 \mathrm{~g} \\
\text { a.i.//ha }\end{array}$ & 7 & \\
\hline Roman rocket & IT & $F$ & Bremia lactucae & SC & $250 \mathrm{~g} / \mathrm{L}$ & $\begin{array}{l}\text { Foliar } \\
\text { treatment } \\
\text { - spraying }\end{array}$ & n.a. & 2 & 7 & - & - & $\begin{array}{l}150 \mathrm{~g} \\
\text { a.i./ha }\end{array}$ & 7 & \\
\hline
\end{tabular}




\begin{tabular}{|c|c|c|c|c|c|c|c|c|c|c|c|c|c|c|}
\hline \multirow[b]{2}{*}{$\begin{array}{l}\text { Crop } \\
\text { and/or } \\
\text { situation }\end{array}$} & \multirow[b]{2}{*}{$\begin{array}{l}\text { NEU, } \\
\text { SEU, MS } \\
\text { or } \\
\text { country }\end{array}$} & \multirow{2}{*}{$\begin{array}{l}\mathbf{F} \\
\mathbf{G} \\
\text { or } \\
\mathbf{I}^{(\mathrm{a})}\end{array}$} & \multirow[b]{2}{*}{$\begin{array}{l}\text { Pests or } \\
\text { Group of pests } \\
\text { controlled }\end{array}$} & \multicolumn{2}{|c|}{ Preparation } & \multicolumn{4}{|c|}{ Application } & \multicolumn{3}{|c|}{$\begin{array}{c}\text { Application rate per } \\
\text { treatment }\end{array}$} & \multirow[b]{2}{*}{$\begin{array}{c}\text { PHI } \\
{\left(\text { days }^{(d)}\right.}^{(d)}\end{array}$} & \multirow[b]{2}{*}{ Remarks } \\
\hline & & & & Type $^{(b)}$ & $\begin{array}{l}\text { Conc. } \\
\text { a.s. }\end{array}$ & $\begin{array}{l}\text { Method } \\
\text { kind }\end{array}$ & $\begin{array}{l}\text { Range of } \\
\text { growth } \\
\text { stages \& } \\
\text { season }^{(c)}\end{array}$ & $\begin{array}{c}\text { Number } \\
\text { min- } \\
\text { max }\end{array}$ & $\begin{array}{c}\text { Interval } \\
\text { between } \\
\text { application } \\
\text { (min) }\end{array}$ & $\begin{array}{c}\text { g } \\
\text { a.s./hL } \\
\min - \\
\max \end{array}$ & $\begin{array}{l}\text { Water } \\
\text { L/ha } \\
\text { min- } \\
\text { max }\end{array}$ & $\begin{array}{l}\text { g } \\
\text { a.s./ha } \\
\text { min- } \\
\text { max }\end{array}$ & & \\
\hline $\begin{array}{l}\text { Baby leaf } \\
\text { crops }\end{array}$ & PT & $\mathrm{F}$ & $\begin{array}{l}\text { Peronospora } \\
\text { parasitica }\end{array}$ & SC & $250 \mathrm{~g} / \mathrm{L}$ & $\begin{array}{l}\text { Foliar } \\
\text { treatment } \\
\text { - spraying }\end{array}$ & n.a. & 2 & & - & - & $\begin{array}{l}150 \mathrm{~g} \\
\text { a.i./ha }\end{array}$ & 7 & \\
\hline Chervil & IT, ES & $\mathrm{F}$ & Peronospora spp. & SC & $250 \mathrm{~g} / \mathrm{L}$ & $\begin{array}{l}\text { Foliar } \\
\text { treatment } \\
\text { - spraying }\end{array}$ & n.a. & 2 & 7 & - & - & $\begin{array}{l}150 \mathrm{~g} \\
\text { a.i./ha }\end{array}$ & 7 & \\
\hline Chives & IT, PT, ES & $\mathrm{F}$ & Peronospora spp. & SC & $250 \mathrm{~g} / \mathrm{L}$ & $\begin{array}{l}\text { Foliar } \\
\text { treatment } \\
\text { - spraying }\end{array}$ & n.a. & 2 & 7 & - & - & $\begin{array}{l}150 \mathrm{~g} \\
\text { a.i./ha }\end{array}$ & 7 & \\
\hline Celery leaves & IT, ES & $\mathrm{F}$ & Peronospora spp. & SC & $250 \mathrm{~g} / \mathrm{L}$ & $\begin{array}{l}\text { Foliar } \\
\text { treatment } \\
\text { - spraying }\end{array}$ & n.a. & 2 & 7 & - & - & $\begin{array}{l}150 \mathrm{~g} \\
\text { a.i./ha }\end{array}$ & 7 & \\
\hline Parsley & IT, PT, ES & $\mathrm{F}$ & Peronospora spp. & SC & $250 \mathrm{~g} / \mathrm{L}$ & $\begin{array}{l}\text { Foliar } \\
\text { treatment } \\
\text { - spraying }\end{array}$ & n.a. & 2 & 7 & - & - & $\begin{array}{l}150 \mathrm{~g} \\
\text { a.i./ha }\end{array}$ & 7 & \\
\hline Sage & IT, ES & $\mathrm{F}$ & Peronospora spp. & SC & $250 \mathrm{~g} / \mathrm{L}$ & $\begin{array}{l}\text { Foliar } \\
\text { treatment } \\
\text { - spraying }\end{array}$ & n.a. & 2 & 7 & - & - & $\begin{array}{l}150 \mathrm{~g} \\
\text { a.i./ha }\end{array}$ & 7 & \\
\hline Rosemary & IT, ES & $\mathrm{F}$ & Peronospora spp. & SC & $250 \mathrm{~g} / \mathrm{L}$ & $\begin{array}{l}\text { Foliar } \\
\text { treatment } \\
\text { - spraying }\end{array}$ & n.a. & 2 & 7 & - & - & $\begin{array}{l}150 \mathrm{~g} \\
\text { a.i./ha }\end{array}$ & 7 & \\
\hline Thyme & IT, ES & $\mathrm{F}$ & Peronospora spp. & SC & $250 \mathrm{~g} / \mathrm{L}$ & $\begin{array}{l}\text { Foliar } \\
\text { treatment } \\
\text { - spraying }\end{array}$ & n.a. & 2 & 7 & - & - & $\begin{array}{l}150 \mathrm{~g} \\
\text { a.i./ha }\end{array}$ & 7 & \\
\hline Basil & IT, ES & $\mathrm{F}$ & Peronospora spp. & SC & $250 \mathrm{~g} / \mathrm{L}$ & $\begin{array}{l}\text { Foliar } \\
\text { treatment } \\
\text { - spraying }\end{array}$ & n.a. & 2 & 7 & - & - & $\begin{array}{l}150 \mathrm{~g} \\
\text { a.i./ha }\end{array}$ & 7 & \\
\hline
\end{tabular}




\begin{tabular}{|c|c|c|c|c|c|c|c|c|c|c|c|c|c|c|}
\hline \multirow[b]{2}{*}{$\begin{array}{l}\text { Crop } \\
\text { and/or } \\
\text { situation }\end{array}$} & \multirow{2}{*}{$\begin{array}{l}\text { NEU, } \\
\text { SEU, MS } \\
\text { or } \\
\text { country }\end{array}$} & \multirow{2}{*}{$\begin{array}{l}\text { F } \\
\text { G } \\
\text { or } \\
\text { I }^{(a)}\end{array}$} & \multirow[b]{2}{*}{$\begin{array}{l}\text { Pests or } \\
\text { Group of pests } \\
\text { controlled }\end{array}$} & \multicolumn{2}{|c|}{ Preparation } & \multicolumn{4}{|c|}{ Application } & \multicolumn{3}{|c|}{$\begin{array}{c}\text { Application rate per } \\
\text { treatment }\end{array}$} & \multirow[b]{2}{*}{$\begin{array}{c}\text { PHI } \\
\text { (days) }^{(d)}\end{array}$} & \multirow[b]{2}{*}{ Remarks } \\
\hline & & & & Type $^{(b)}$ & $\begin{array}{l}\text { Conc. } \\
\text { a.s. }\end{array}$ & $\begin{array}{l}\text { Method } \\
\text { kind }\end{array}$ & $\begin{array}{l}\text { Range of } \\
\text { growth } \\
\text { stages \& } \\
\text { season }^{(c)}\end{array}$ & $\begin{array}{c}\text { Number } \\
\text { min- } \\
\text { max }\end{array}$ & $\begin{array}{c}\text { Interval } \\
\text { between } \\
\text { application } \\
\text { (min) }\end{array}$ & $\begin{array}{c}\mathbf{g} \\
\text { a.s./hL } \\
\min - \\
\max \end{array}$ & $\begin{array}{l}\text { Water } \\
\text { L/ha } \\
\text { min- } \\
\text { max }\end{array}$ & $\begin{array}{l}\text { g } \\
\text { a.s./ha } \\
\text { min- } \\
\text { max }\end{array}$ & & \\
\hline Laurel & ES & $\mathrm{F}$ & Peronospora spp. & $\mathrm{SC}$ & $250 \mathrm{~g} / \mathrm{L}$ & $\begin{array}{l}\text { Foliar } \\
\text { treatment } \\
\text { - spraying }\end{array}$ & n.a. & 2 & 7 & - & - & $\begin{array}{l}150 \mathrm{~g} \\
\text { a.i./ha }\end{array}$ & 7 & \\
\hline Tarragon & IT, ES & $\mathrm{F}$ & Peronospora spp. & $\mathrm{SC}$ & $250 \mathrm{~g} / \mathrm{L}$ & $\begin{array}{l}\text { Foliar } \\
\text { treatment } \\
\text { - spraying } \\
\end{array}$ & n.a. & 2 & 7 & - & - & $\begin{array}{l}150 \mathrm{~g} \\
\text { a.i./ha }\end{array}$ & 7 & \\
\hline
\end{tabular}

a.i.: active ingredient, SC: suspension concentrate; WG: water dispersible granule; n.a.: not applicable.

(a): Outdoor or field use (F), greenhouse application (G) or indoor application (I).

(b): CropLife International Technical Monograph no 2, 6th Edition. Revised May 2008. Catalogue of pesticide.

(c): Growth stage range from first to last treatment (BBCH Monograph, Growth Stages of Plants, 1997, Blackwell, ISBN 3-8263-3152-4), including, where relevant, information on season at time of application.

(d): PHI - minimum pre-harvest interval. 


\section{A.3. Authorised indoor uses in the EU}

\begin{tabular}{|c|c|c|c|c|c|c|c|c|c|c|c|c|c|c|}
\hline \multirow[b]{2}{*}{$\begin{array}{l}\text { Crop } \\
\text { and/or } \\
\text { situation }\end{array}$} & \multirow{2}{*}{$\begin{array}{l}\text { NEU, SEU, } \\
\text { MS } \\
\text { or } \\
\text { country }\end{array}$} & \multirow{2}{*}{$\begin{array}{l}\mathbf{F} \\
\mathbf{G} \\
\text { or } \\
\mathbf{I}^{(\mathbf{a})}\end{array}$} & \multirow[b]{2}{*}{$\begin{array}{l}\text { Pests or } \\
\text { Group of pests } \\
\text { controlled }\end{array}$} & \multicolumn{2}{|c|}{ Preparation } & \multicolumn{4}{|c|}{ Application } & \multicolumn{3}{|c|}{$\begin{array}{c}\text { Application rate per } \\
\text { treatment }\end{array}$} & \multirow[b]{2}{*}{$\begin{array}{c}\text { PHI } \\
\text { (days) }^{(d)}\end{array}$} & \multirow[b]{2}{*}{ Remarks } \\
\hline & & & & Type $^{(b)}$ & $\begin{array}{l}\text { Conc. } \\
\text { a.s. }\end{array}$ & $\begin{array}{l}\text { Method } \\
\text { kind }\end{array}$ & $\begin{array}{l}\text { Range of } \\
\text { growth } \\
\text { stages \& } \\
\text { season (c) }\end{array}$ & $\begin{array}{c}\text { Number } \\
\text { min- } \\
\text { max }\end{array}$ & $\begin{array}{c}\text { Interval } \\
\text { between } \\
\text { application } \\
\text { (min) }\end{array}$ & $\begin{array}{c}\text { g } \\
\text { a.s./hL } \\
\text { min- } \\
\max \end{array}$ & $\begin{array}{l}\text { Water } \\
\text { L/ha } \\
\text { min- } \\
\text { max }\end{array}$ & $\begin{array}{c}\text { g } \\
\text { a.s./ha } \\
\text { min- } \\
\text { max }\end{array}$ & & \\
\hline Tomatoes & $\begin{array}{l}\mathrm{IT}, \mathrm{LV}, \mathrm{SE} \\
\mathrm{BE}, \mathrm{EL}, \mathrm{PT}, \\
\mathrm{ES}, \mathrm{FI}, \mathrm{DE}\end{array}$ & I & $\begin{array}{l}\text { Phytophthora } \\
\text { infestans }\end{array}$ & WG & $50 \mathrm{~g} / \mathrm{kg}$ & $\begin{array}{l}\text { Foliar } \\
\text { treatment } \\
\text { - spraying }\end{array}$ & n.a. & 4 & 7 & - & - & $\begin{array}{l}150 \mathrm{~g} \\
\text { a.i./ha }\end{array}$ & 3 & \\
\hline Aubergines & $\mathrm{BE}, \mathrm{CZ}, \mathrm{DE}$ & I & Downy mildew & SC & $250 \mathrm{~g} / \mathrm{L}$ & $\begin{array}{l}\text { Foliar } \\
\text { treatment } \\
\text { - spraying }\end{array}$ & n.a. & 4 & & - & - & $\begin{array}{l}150 \mathrm{~g} \\
\text { a.i./ha }\end{array}$ & 3 & \\
\hline Cucumbers & IE, LV & I & & SC & $250 \mathrm{~g} / \mathrm{L}$ & $\begin{array}{l}\text { Foliar } \\
\text { treatment } \\
\text { - spraying }\end{array}$ & n.a. & 4 & 7 & - & - & $\begin{array}{l}150 \mathrm{~g} \\
\text { a.i./ha }\end{array}$ & 3 & \\
\hline Courgettes & $\mathrm{IE}, \mathrm{DE}$ & I & & SC & $250 \mathrm{~g} / \mathrm{L}$ & $\begin{array}{l}\text { Foliar } \\
\text { treatment } \\
\text { - spraying }\end{array}$ & n.a. & 4 & & - & - & $\begin{array}{l}150 \mathrm{~g} \\
\text { a.i./ha }\end{array}$ & 3 & \\
\hline Melons & $\begin{array}{l}\mathrm{IT}, \mathrm{EL}, \mathrm{ES} \\
\mathrm{DE}\end{array}$ & I & $\begin{array}{l}\text { Pseudoperonospora } \\
\text { cubensis }\end{array}$ & SC & $250 \mathrm{~g} / \mathrm{L}$ & $\begin{array}{l}\text { Foliar } \\
\text { treatment } \\
\text { - spraying }\end{array}$ & n.a. & 4 & 7 & - & - & $\begin{array}{l}150 \mathrm{~g} \\
\text { a.i.//ha }\end{array}$ & 3 & \\
\hline Pumpkins & $\mathrm{DE}$ & I & $\begin{array}{l}\text { Pseudoperonospora } \\
\text { cubensis }\end{array}$ & SC & $250 \mathrm{~g} / \mathrm{L}$ & $\begin{array}{l}\text { Foliar } \\
\text { treatment } \\
\text { - spraying }\end{array}$ & n.a. & 4 & 7 & - & - & $\begin{array}{l}150 \mathrm{~g} \\
\text { a.i./ha }\end{array}$ & 3 & \\
\hline $\begin{array}{l}\text { Lamb's } \\
\text { lettuces }\end{array}$ & AT & I & $\begin{array}{l}\text { Bremia lactucae, } \\
\text { Peronospora } \\
\text { parasitica }\end{array}$ & WG & $250 \mathrm{~g} / \mathrm{L}$ & $\begin{array}{l}\text { Foliar } \\
\text { treatment } \\
\text { - spraying }\end{array}$ & n.a. & 2 & 7 & - & - & $\begin{array}{l}150 \mathrm{~g} \\
\text { a.i./ha }\end{array}$ & 7 & \\
\hline Lettuces & $\begin{array}{l}\text { PT, ES, UK, } \\
\text { DE, IT }\end{array}$ & I & Peronosporaceae & SC & $250 \mathrm{~g} / \mathrm{L}$ & $\begin{array}{l}\text { Foliar } \\
\text { treatment } \\
\text { - spraying }\end{array}$ & n.a. & 1 & & - & - & $\begin{array}{l}150 \mathrm{~g} \\
\text { a.i./ha }\end{array}$ & 7 & \\
\hline Escaroles & $\begin{array}{l}\text { IT, ES, EL, } \\
\text { PT, DE }\end{array}$ & I & Peronosporaceae & SC & $250 \mathrm{~g} / \mathrm{L}$ & $\begin{array}{l}\text { Foliar } \\
\text { treatment } \\
\text { - spraying }\end{array}$ & n.a. & 1 & & - & - & $\begin{array}{l}150 \mathrm{~g} \\
\text { a.i.//ha }\end{array}$ & 7 & \\
\hline Cresses & AT & I & $\begin{array}{l}\text { Bremia lactucae, } \\
\text { Peronospora } \\
\text { parasitica }\end{array}$ & WG & $250 \mathrm{~g} / \mathrm{L}$ & $\begin{array}{l}\text { Foliar } \\
\text { treatment } \\
\text { - spraying }\end{array}$ & n.a. & 2 & 7 & - & - & $\begin{array}{l}150 \mathrm{~g} \\
\text { a.i./ha }\end{array}$ & 7 & \\
\hline
\end{tabular}




\begin{tabular}{|c|c|c|c|c|c|c|c|c|c|c|c|c|c|c|}
\hline \multirow[b]{2}{*}{$\begin{array}{l}\text { Crop } \\
\text { and/or } \\
\text { situation }\end{array}$} & \multirow{2}{*}{$\begin{array}{l}\text { NEU, SEU, } \\
\text { MS } \\
\text { or } \\
\text { country }\end{array}$} & \multirow{2}{*}{$\begin{array}{l}\mathbf{F} \\
\mathbf{G} \\
\text { or } \\
\mathbf{I}^{(a)}\end{array}$} & \multirow[b]{2}{*}{$\begin{array}{l}\text { Pests or } \\
\text { Group of pests } \\
\text { controlled }\end{array}$} & \multicolumn{2}{|c|}{ Preparation } & \multicolumn{4}{|c|}{ Application } & \multicolumn{3}{|c|}{$\begin{array}{c}\text { Application rate per } \\
\text { treatment }\end{array}$} & \multirow[b]{2}{*}{$\begin{array}{c}\text { PHI } \\
\text { (days) }^{(d)}\end{array}$} & \multirow[b]{2}{*}{ Remarks } \\
\hline & & & & Type $^{(b)}$ & $\begin{array}{l}\text { Conc. } \\
\text { a.s. }\end{array}$ & $\begin{array}{l}\text { Method } \\
\text { kind }\end{array}$ & $\begin{array}{l}\text { Range of } \\
\text { growth } \\
\text { stages \& } \\
\text { season }\end{array}$ & $\begin{array}{c}\text { Number } \\
\text { min- } \\
\text { max }\end{array}$ & $\begin{array}{c}\text { Interval } \\
\text { between } \\
\text { application } \\
\text { (min) }\end{array}$ & $\begin{array}{c}\text { g } \\
\text { a.s./hL } \\
\min - \\
\max \end{array}$ & $\begin{array}{l}\text { Water } \\
\text { L/ha } \\
\text { min- } \\
\text { max }\end{array}$ & $\begin{array}{l}\text { g } \\
\text { a.s./ha } \\
\text { min- } \\
\text { max }\end{array}$ & & \\
\hline Land cresses & $\mathrm{DE}$ & I & Peronosporaceae & SC & $250 \mathrm{~g} / \mathrm{L}$ & $\begin{array}{l}\text { Foliar } \\
\text { treatment } \\
\text { - spraying }\end{array}$ & n.a. & 2 & & - & - & $\begin{array}{l}150 \mathrm{~g} \\
\text { a.i.//ha }\end{array}$ & 7 & \\
\hline Roman rocket & $\begin{array}{l}\text { IT, PT, ES, } \\
\text { EL, BE, DE }\end{array}$ & I & Bremia lactucae & SC & $250 \mathrm{~g} / \mathrm{L}$ & $\begin{array}{l}\text { Foliar } \\
\text { treatment } \\
\text { - spraying }\end{array}$ & n.a. & 1 & 7 & - & - & $\begin{array}{l}150 \mathrm{~g} \\
\text { a.i./ha }\end{array}$ & 7 & \\
\hline Red mustards & $\begin{array}{l}\mathrm{BE}, \mathrm{EL}, \mathrm{PT}, \\
\mathrm{ES}, \mathrm{DE}\end{array}$ & I & & SC & $250 \mathrm{~g} / \mathrm{L}$ & $\begin{array}{l}\text { Foliar } \\
\text { treatment } \\
\text { - spraying }\end{array}$ & n.a. & 1 & & - & - & $\begin{array}{l}150 \mathrm{~g} \\
\text { a.i./ha }\end{array}$ & 7 & \\
\hline $\begin{array}{l}\text { Baby leaf } \\
\text { crops }\end{array}$ & $\begin{array}{l}\mathrm{BE}, \mathrm{UK}, \mathrm{PT} \text {, } \\
\mathrm{ES}, \mathrm{DE}\end{array}$ & I & & SC & $250 \mathrm{~g} / \mathrm{L}$ & $\begin{array}{l}\text { Foliar } \\
\text { treatment } \\
\text { - spraying }\end{array}$ & n.a. & 1 & & - & - & $\begin{array}{l}150 \mathrm{~g} \\
\text { a.i.//ha }\end{array}$ & 7 & \\
\hline Spinaches & PT & I & & SC & $250 \mathrm{~g} / \mathrm{L}$ & $\begin{array}{l}\text { Foliar } \\
\text { treatment } \\
\text { - spraying }\end{array}$ & n.a. & 2 & 7 & - & - & $\begin{array}{l}150 \mathrm{~g} \\
\text { a.i.//ha }\end{array}$ & 7 & \\
\hline Purslanes & AT & I & $\begin{array}{l}\text { Bremia lactucae, } \\
\text { Peronospora } \\
\text { parasitica }\end{array}$ & WG & $250 \mathrm{~g} / \mathrm{L}$ & $\begin{array}{l}\text { Foliar } \\
\text { treatment } \\
\text { - spraying }\end{array}$ & n.a. & 2 & 7 & - & - & $\begin{array}{l}150 \mathrm{~g} \\
\text { a.i.//ha }\end{array}$ & 7 & \\
\hline Chards & $\begin{array}{l}\mathrm{BE}, \mathrm{EL}, \mathrm{PT}, \\
\mathrm{ES}, \mathrm{DE}\end{array}$ & I & & SC & $250 \mathrm{~g} / \mathrm{L}$ & $\begin{array}{l}\text { Foliar } \\
\text { treatment } \\
\text { - spraying }\end{array}$ & n.a. & 1 & & - & - & $\begin{array}{l}150 \mathrm{~g} \\
\text { a.i./ha }\end{array}$ & 7 & \\
\hline Chervil & ES & I & Peronospora spp. & SC & $250 \mathrm{~g} / \mathrm{L}$ & $\begin{array}{l}\text { Foliar } \\
\text { treatment } \\
\text { - spraying }\end{array}$ & n.a. & 2 & 7 & - & - & $\begin{array}{l}150 \mathrm{~g} \\
\text { a.i./ha }\end{array}$ & 7 & \\
\hline Chives & ES, PT & I & Peronospora spp. & SC & $250 \mathrm{~g} / \mathrm{L}$ & $\begin{array}{l}\text { Foliar } \\
\text { treatment } \\
\text { - spraying }\end{array}$ & n.a. & 2 & 7 & - & - & $\begin{array}{l}150 \mathrm{~g} \\
\text { a.i.//ha }\end{array}$ & 7 & \\
\hline Celery leaves & ES & I & Peronospora spp. & SC & $250 \mathrm{~g} / \mathrm{L}$ & $\begin{array}{l}\text { Foliar } \\
\text { treatment } \\
\text { - spraying }\end{array}$ & n.a. & 2 & 7 & - & - & $\begin{array}{l}150 \mathrm{~g} \\
\text { a.i./ha }\end{array}$ & 7 & \\
\hline
\end{tabular}




\begin{tabular}{|c|c|c|c|c|c|c|c|c|c|c|c|c|c|c|}
\hline \multirow[b]{2}{*}{$\begin{array}{l}\text { Crop } \\
\text { and/or } \\
\text { situation }\end{array}$} & \multirow{2}{*}{$\begin{array}{l}\text { NEU, SEU, } \\
\text { MS } \\
\text { or } \\
\text { country }\end{array}$} & \multirow{2}{*}{$\begin{array}{l}\mathbf{F} \\
\mathbf{G} \\
\text { or } \\
\mathbf{I}^{(a)}\end{array}$} & \multirow[b]{2}{*}{$\begin{array}{l}\text { Pests or } \\
\text { Group of pests } \\
\text { controlled }\end{array}$} & \multicolumn{2}{|c|}{ Preparation } & \multicolumn{4}{|c|}{ Application } & \multicolumn{3}{|c|}{$\begin{array}{c}\text { Application rate per } \\
\text { treatment }\end{array}$} & \multirow[b]{2}{*}{$\begin{array}{c}\text { PHI } \\
\text { (days) }^{(d)}\end{array}$} & \multirow[b]{2}{*}{ Remarks } \\
\hline & & & & Type $^{(b)}$ & $\begin{array}{l}\text { Conc. } \\
\text { a.s. }\end{array}$ & $\begin{array}{l}\text { Method } \\
\text { kind }\end{array}$ & $\begin{array}{l}\text { Range of } \\
\text { growth } \\
\text { stages \& } \\
\text { season (c) }\end{array}$ & $\begin{array}{c}\text { Number } \\
\text { min- } \\
\text { max }\end{array}$ & $\begin{array}{l}\text { Interval } \\
\text { between } \\
\text { application } \\
\text { (min) }\end{array}$ & $\begin{array}{c}\text { g } \\
\text { a.s./hL } \\
\min - \\
\max \end{array}$ & $\begin{array}{l}\text { Water } \\
\text { L/ha } \\
\text { min- } \\
\text { max }\end{array}$ & $\begin{array}{c}\text { g } \\
\text { a.s./ha } \\
\text { min- } \\
\text { max }\end{array}$ & & \\
\hline Parsley & ES & I & Peronospora spp. & $\mathrm{SC}$ & $250 \mathrm{~g} / \mathrm{L}$ & $\begin{array}{l}\text { Foliar } \\
\text { treatment } \\
\text { - spraying }\end{array}$ & n.a. & 2 & 7 & - & - & $\begin{array}{l}150 \mathrm{~g} \\
\text { a.i./ha }\end{array}$ & 7 & \\
\hline Sage & ES & I & Peronospora spp. & SC & $250 \mathrm{~g} / \mathrm{L}$ & $\begin{array}{l}\text { Foliar } \\
\text { treatment } \\
\text { - spraying }\end{array}$ & n.a. & 2 & 7 & - & - & $\begin{array}{l}150 \mathrm{~g} \\
\text { a.i./ha }\end{array}$ & 7 & \\
\hline Rosemary & ES & I & Peronospora spp. & $\mathrm{SC}$ & $250 \mathrm{~g} / \mathrm{L}$ & $\begin{array}{l}\text { Foliar } \\
\text { treatment } \\
\text { - spraying }\end{array}$ & n.a. & 2 & 7 & - & - & $\begin{array}{l}150 \mathrm{~g} \\
\text { a.i./ha }\end{array}$ & 7 & \\
\hline Thyme & ES & I & Peronospora spp. & $\mathrm{SC}$ & $250 \mathrm{~g} / \mathrm{L}$ & $\begin{array}{l}\text { Foliar } \\
\text { treatment } \\
\text { - spraying }\end{array}$ & n.a. & 2 & 7 & - & - & $\begin{array}{l}150 \mathrm{~g} \\
\text { a.i./ha }\end{array}$ & 7 & \\
\hline Basil & ES & I & Peronospora spp. & $\mathrm{SC}$ & $250 \mathrm{~g} / \mathrm{L}$ & $\begin{array}{l}\text { Foliar } \\
\text { treatment } \\
\text { - spraying }\end{array}$ & n.a. & 2 & 7 & - & - & $\begin{array}{l}150 \mathrm{~g} \\
\text { a.i./ha }\end{array}$ & 7 & \\
\hline Laurel & ES & I & Peronospora spp. & SC & $250 \mathrm{~g} / \mathrm{L}$ & $\begin{array}{l}\text { Foliar } \\
\text { treatment } \\
\text { - spraying }\end{array}$ & n.a. & 2 & 7 & - & - & $\begin{array}{l}150 \mathrm{~g} \\
\text { a.i./ha }\end{array}$ & 7 & \\
\hline Tarragon & ES & I & Peronospora spp. & $\mathrm{SC}$ & $250 \mathrm{~g} / \mathrm{L}$ & $\begin{array}{l}\text { Foliar } \\
\text { treatment } \\
\text { - spraying }\end{array}$ & n.a. & 2 & 7 & - & - & $\begin{array}{l}150 \mathrm{~g} \\
\text { a.i./ha }\end{array}$ & 7 & \\
\hline
\end{tabular}

a.i.: active ingredient, SC: suspension concentrate; WG: water dispersible granule; n.a.: not applicable.

(a): Outdoor or field use (F), greenhouse application (G) or indoor application (I).

(b): CropLife International Technical Monograph no 2, 6th Edition. Revised May 2008. Catalogue of pesticide.

(c): Growth stage range from first to last treatment (BBCH Monograph, Growth Stages of Plants, 1997, Blackwell, ISBN 3-8263-3152-4), including, where relevant, information on season at time of application.

(d): PHI - minimum pre-harvest interval. 


\section{Appendix B - List of end points}

\section{B.1. Residues in plants}

\section{B.1.1. Nature of residues and methods of analysis in plants}

B.1.1.1. Metabolism studies, methods of analysis and residue definitions in plants

\begin{tabular}{|c|c|c|c|c|}
\hline \multirow[t]{9}{*}{$\begin{array}{l}\text { Primary crops } \\
\text { (available studies) }\end{array}$} & Crop groups & Crop(s) & Application(s) & Sampling (DAT) \\
\hline & \multirow[t]{3}{*}{ Fruit crops } & \multirow[t]{2}{*}{ Grapes $^{(a)}$} & Foliar, $6 \times 143-150 \mathrm{~g}$ a.s./ha & $0,14,28$ (fruits and leaves) \\
\hline & & & Foliar, $6 \times 411-464 \mathrm{~g}$ a.s./ha & 28 (fruits and leaves) \\
\hline & & Tomato $^{(b)}$ & Foliar, $4 \times(149-276) \mathrm{g}$ a.s./ha & $0,3,7,14,28$ \\
\hline & \multirow[t]{2}{*}{ Root crops } & \multirow[t]{2}{*}{ Potato $^{(a)}$} & Foliar, $6 \times 46-158 \mathrm{~g}$ a.s./ha & 7, 21 (tubers and leaves) \\
\hline & & & Foliar, $6 \times 418-458 \mathrm{~g}$ a.s./ha & 7, 21 (tubers and leaves) \\
\hline & \multirow[t]{2}{*}{ Leafy crops } & \multirow[t]{2}{*}{ Lettuce $^{(a)}$} & Foliar, $2 \times 156-160 \mathrm{~g}$ a.s./ha & \multirow[t]{2}{*}{3,14} \\
\hline & & & Foliar, $2 \times 418-458 \mathrm{~g}$ a.s./ha & \\
\hline & \multicolumn{4}{|c|}{$\begin{array}{l}\text { Source: EFSA, } 2012 . \\
\text { (a) study with chlorophenyl- }{ }^{14} \mathrm{C} \text { or methoxyphenyl- }{ }^{14} \mathrm{C} \text { - labelled mandipropamid. } \\
\text { (b) study with }\left[1-\mathrm{C}^{14}\right] \text { labelled mandipropamid. }\end{array}$} \\
\hline \multirow[t]{5}{*}{$\begin{array}{l}\text { Rotational crops } \\
\text { (available studies) }\end{array}$} & Crop groups & Crop(s) & Application(s) & $\begin{array}{l}\text { PBI } \\
\left(_{(D A T)}\right)^{(b)}\end{array}$ \\
\hline & Root/tuber crops & Radish $^{(a)}$ & Bare soil, $1 \times 900 \mathrm{~g}$ a.s./ha & $29,58,120,365$ \\
\hline & Leafy crops & Lettuce $^{(a)}$ & Bare soil, $1 \times 900 \mathrm{~g}$ a.s./ha & $29,58,120,365$ \\
\hline & $\begin{array}{l}\text { Cereal (small } \\
\text { grain) }\end{array}$ & $\begin{array}{l}\text { Spring } \\
\text { wheat }^{(a)}\end{array}$ & Bare soil, 1 × $900 \mathrm{~g}$ a.s./ha & $29,58,120,365$ \\
\hline & \multicolumn{4}{|c|}{$\begin{array}{l}\text { Source: EFSA, } 2012 . \\
\text { (a) study with chlorophenyl- }{ }^{14} \mathrm{C} \text { or methoxyphenyl- }{ }^{14} \mathrm{C} \text { - labelled mandipropamid. }\end{array}$} \\
\hline \multirow{5}{*}{$\begin{array}{l}\text { Processed } \\
\text { commodities } \\
\text { (hydrolysis study) }\end{array}$} & \multicolumn{3}{|l|}{ Conditions } & Investigated? ${ }^{(a)}$ \\
\hline & \multicolumn{3}{|c|}{ Pasteurisation $\left(20 \mathrm{~min}, 90^{\circ} \mathrm{C}, \mathrm{pH} 4\right)$} & Yes \\
\hline & \multicolumn{3}{|c|}{ Baking, brewing and boiling $\left(60 \mathrm{~min}, 100^{\circ} \mathrm{C}, \mathrm{pH} 5\right)$} & Yes \\
\hline & \multicolumn{3}{|c|}{ Sterilisation $\left(20 \mathrm{~min}, 120^{\circ} \mathrm{C}, \mathrm{pH} 6\right)$} & Yes \\
\hline & \multicolumn{4}{|c|}{$\begin{array}{l}\text { Source: EFSA, } 2012 . \\
\text { (a) study with chlorophenyl- }{ }^{14} \mathrm{C} \text { or methoxyphenyl- }{ }^{14} \mathrm{C} \text { - labelled mandipropamid. }\end{array}$} \\
\hline
\end{tabular}




\begin{tabular}{|c|c|}
\hline $\begin{array}{l}\text { Can a general residue definition be proposed for } \\
\text { primary crops? }\end{array}$ & No \\
\hline $\begin{array}{l}\text { Rotational crop and primary crop metabolism } \\
\text { similar? }\end{array}$ & Yes \\
\hline $\begin{array}{l}\text { Residue pattern in processed commodities similar } \\
\text { to residue pattern in raw commodities? }\end{array}$ & Yes \\
\hline Plant residue definition for monitoring (RD-Mo) & mandipropamid (any ratio of constituent isomers) \\
\hline Plant residue definition for risk assessment (RD-RA) & $\begin{array}{l}\text { Fruits and leafy vegetables: mandipropamid (any ratio of } \\
\text { constituent isomers) } \\
\text { Root crops: sum of mandipropamid and SYN } 500003 \\
\text { [tentative, pending on the submission of toxicological } \\
\text { information on SYN 500003] }\end{array}$ \\
\hline Conversion factor (monitoring to risk assessment) & See section B.1.2.1 \\
\hline $\begin{array}{l}\text { Methods of analysis for monitoring of residues } \\
\text { (analytical technique, crop groups, LOQs) }\end{array}$ & $\begin{array}{ll}\text { LC-MS/MS (EFSA, } & \text { 2012) } \\
\text { - } & \text { LOQ } 0.01 \mathrm{mg} / \mathrm{kg} \text { for all plant matrices; } \\
\text { - } & \text { ILV available. }\end{array}$ \\
\hline
\end{tabular}

a.i.: active substance; DAT: days after treatment; PBI: plant-back interval; LC-MS/MS: liquid chromatography with tandem mass spectrometry; LOQ: limit of quantification; ILV: independent laboratory validation.

\section{B.1.1.2. Stability of residues in plants}

\begin{tabular}{|c|c|c|c|c|}
\hline $\begin{array}{l}\text { Plant products } \\
\text { (available studies) }\end{array}$ & Category & Commodity & $\mathbf{T}\left({ }^{\circ} \mathbf{C}\right)$ & $\begin{array}{l}\text { Stability } \\
\text { (Months/years) }\end{array}$ \\
\hline & \multirow[t]{2}{*}{ High water content } & Tomatoes $^{(a)}$, lettuce ${ }^{(a)}$, cucumber ${ }^{(a)}$ & -20 & 24 months \\
\hline & & potatoes $^{(\mathrm{b})}$ & -20 & 32 months \\
\hline & High oil content & Soyabeans ${ }^{(a)}$ & -20 & 24 months \\
\hline & Dry & Wheat $^{(a)}$ & -20 & 24 months \\
\hline & High acid content & Grapes $^{(a)}$ & -20 & 24 months \\
\hline & \multicolumn{4}{|c|}{$\begin{array}{l}\text { Source: Austria, } 2013 . \\
\text { (a) Mandipropamid only. } \\
\text { (b) Metabolite SYN } 500003 \text { was stable in potato tubers, qranules/flakes, chips and wet peel. }\end{array}$} \\
\hline
\end{tabular}




\section{B.1.2. Magnitude of residues in plants}

B.1.2.1. Summary of residues data from the supervised residue trials

\begin{tabular}{|c|c|c|c|c|c|c|c|}
\hline Crop & $\begin{array}{l}\text { Region/ } \\
\text { indoor }^{(a)}\end{array}$ & $\begin{array}{l}\text { Residue levels observed in the } \\
\text { supervised residue trials relevant } \\
\text { to the supported GAPs (mg/kg) }\end{array}$ & $\begin{array}{l}\text { Recommendations/comments } \\
\text { (OECD calculations) }\end{array}$ & $\begin{array}{c}\text { MRL } \\
\text { proposals } \\
(\mathrm{mg} / \mathrm{kg})\end{array}$ & $\begin{array}{l}\mathrm{HR}_{\text {Mo }} \\
(\mathrm{mg} / \\
\mathrm{kg})^{(\mathrm{b})}\end{array}$ & $\begin{array}{l}\text { STMR }_{\text {Mo }} \\
(\mathbf{m g} / \\
\mathbf{k g})^{(\mathrm{c})}\end{array}$ & $\mathrm{CF}^{(\mathrm{d})}$ \\
\hline
\end{tabular}

Residue definition for enforcement: mandipropamid (any ratio of constituent isomers)

Residue definition for risk assessment: sum of mandipropamid and SYN 500003 [tentative, pending on information on the toxicological of metabolite SYN 500003]

Potatoes

$$
\begin{array}{l|l}
\text { NEU } & \text { Mo: } 8 \times<0.01 \\
\text { RA: } 8 \times 0.01
\end{array}
$$

SEU Mo: $8 \times<0.01$

RA: $6 \times 0.01 ; 0.020 ; 0.021$
Results for metabolite SYN 500003

$8 \times<0.005 \mathrm{mg} / \mathrm{kg}$ (LOQ).

Trials compliant with GAP (Austria, 2013)

Results for metabolite SYN 500003

$6 \times<0.005 ; 0.010 ; 0.011 \mathrm{mg} / \mathrm{kg}$. (tentative) $^{(\mathrm{f})}$

$0.01^{*}$

${\text { (tentative })^{(f)}}^{(f)}$
0.01

0.01

$2^{(\mathrm{e})}$

Residue definition for enforcement: mandipropamid (any ratio of constituent isomers)

Residue definition for risk assessment: mandipropamid (any ratio of constituent isomers)

Table grapes

Wine grapes

$$
\text { NEU } \quad 0.08 ; 0.09 ; 0.15 ; 0.20 ; 0.22 ; 0.23 \text {; }
$$

$$
0.27 ; 0.42 ; 0.43
$$

rials with 4 applications of $150 \mathrm{~g}$ a.s./ha deemed acceptable (Austria, 2013) $\mathrm{MRL}_{\mathrm{OECD}}=0.74$

SEU $\quad 0.11 ; 0.20 ; 0.26 ; 0.28 ; 0.35 ; 0.38 ;$ $0.44 ; 0.82 ; 0.90$

Tomatoes NEU

$0.08 ; 0.10 ; 0.39$

Aubergines/eggplants

\begin{tabular}{l|l} 
SEU & $\begin{array}{l}0.03 ; 0.04 ; 0.06 ; 0.07 ; 0.10 ; 0.12 ; \\
0.14 ; 0.15 ; 0.17 ; 0.32\end{array}$ \\
& \\
\hline EU & $\begin{array}{l}0.30 ; 0.33 ; 0.34 ; 0.52 ; 0.60 ; 0.23 ; \\
0.28 ; 0.56 ; 1.70\end{array}$
\end{tabular}

$0.28 ; 0.56 ; 1.70$
Trials compliant with GAP (Austria, 2013). Some values from longer PHI but higher residue levels. Extrapolation to wine grapes is applicable.

MRL

Trials compliant with GAP (Austria, 2013). GAP for tomatoes only.

Trials compliant with GAP (Austria, 2013)

Some values are from longer PHI, but

higher residue levels. GAP for tomatoes only.

MRL

Trials on cherry tomatoes (EFSA, 2013)

Last four results from three applications instead of four are deemed acceptable.

Some values are from longer PHI, but

higher residue levels. Extrapolation to

aubergines is applicable.

$M R L_{O E C D}=2.36$

\begin{tabular}{|l|l|l|l|}
\hline 0.8 & 0.43 & 0.22 & - \\
\hline 1.5 & 0.90 & 0.35 & - \\
\hline- & - & - & - \\
\hline 0.5 & 0.32 & 0.11 & - \\
\hline & & & \\
\hline 3 & 1.70 & 0.34 & - \\
& & & \\
\hline
\end{tabular}




\begin{tabular}{|c|c|c|c|c|c|c|c|}
\hline Crop & $\begin{array}{l}\text { Region/ } \\
\text { indoor }^{(a)}\end{array}$ & $\begin{array}{l}\text { Residue levels observed in the } \\
\text { supervised residue trials relevant } \\
\text { to the supported GAPs ( } \mathrm{mg} / \mathrm{kg} \text { ) }\end{array}$ & $\begin{array}{l}\text { Recommendations/comments } \\
\text { (OECD calculations) }\end{array}$ & $\begin{array}{c}\text { MRL } \\
\text { proposals } \\
(\mathrm{mg} / \mathrm{kg})\end{array}$ & $\begin{array}{l}\mathrm{HR}_{\text {Mo }} \\
(\mathbf{m g} / \\
\mathbf{k g})^{(\mathrm{b})}\end{array}$ & $\begin{array}{l}\text { STMR }_{\text {Mo }} \\
(\mathbf{m g} / \\
\mathrm{kg})^{(\mathrm{c})}\end{array}$ & $\mathrm{CF}^{(\mathrm{d})}$ \\
\hline Cucumbers & EU & $\begin{array}{l}2 \times 0.02 ; 0.03 ; 0.04 ; 0.06 ; 2 \times 0.07 ; \\
0.09\end{array}$ & $\begin{array}{l}\text { Trials compliant with GAP (Austria, 2013). } \\
\text { MRL }_{O E C D}=015\end{array}$ & 0.15 & 0.09 & 0.05 & - \\
\hline \multirow{3}{*}{ Courgettes } & NEU & - & No data available. & - & - & - & - \\
\hline & SEU & $0.01 ; 3 \times 0.02 ; 3 \times 0,03$ & $\begin{array}{l}\text { Trials performed on cucumbers (Austria, } \\
\text { 2013). Extrapolation to courgettes is } \\
\text { applicable. } \\
\text { MRLOECD }=0.07\end{array}$ & 0.07 & 0.03 & 0.02 & - \\
\hline & EU & $\begin{array}{l}2 \times 0.02 ; 0.03 ; 0.04 ; 0.06 ; 2 \times 0.07 ; \\
0.09\end{array}$ & $\begin{array}{l}\text { Direct extrapolation from cucumbers indoor. } \\
\text { MRL }_{\mathrm{OECD}}=015\end{array}$ & 0.15 & 0.09 & 0.05 & - \\
\hline \multirow[t]{2}{*}{ MelonsPumpkins } & SEU & $2 \times 0.03 ; 3 \times 0.04 ; 0.05 ; 0.10 ; 0.13$ & $\begin{array}{l}\text { Trials compliant with GAP (Austria, 2013). } \\
\text { Some results from longer PHI but higher } \\
\text { residue levels. Extrapolation to pumpkins is } \\
\text { applicable. } \\
\text { MRL }_{\mathrm{OECD}}=0.21\end{array}$ & 0.2 & 0.13 & 0.04 & - \\
\hline & EU & $\begin{array}{l}0.03 ; 0.05 ; 2 \times 0.06 ; 0.08 ; 0.09 ; \\
0.12 ; 0.19 ;\end{array}$ & $\begin{array}{l}\text { Trials compliant with GAP (Austria, 2013). } \\
\text { Extrapolation to pumpkins is applicable. } \\
\text { MRL }_{\text {OECD }}=0.29\end{array}$ & 0.3 & 0.19 & 0.07 & - \\
\hline \multirow{2}{*}{$\begin{array}{l}\text { Lettuces } \\
\text { Lamb's lettuce } \\
\text { Escaroles } \\
\text { Roman rocket/rucola } \\
\text { Red mustards } \\
\text { Baby leaf crops } \\
\text { Chards } \\
\text { Cresses } \\
\text { Land cresses } \\
\text { Spinaches } \\
\text { Purslanes } \\
\text { Fresh herbs }\end{array}$} & NEU & $\begin{array}{l}0.11 ; 0.27 ; 0.43 ; 0.47 ; 0.50 ; 1.20 ; \\
1.30 ; 1.60\end{array}$ & $\begin{array}{l}\text { Trials performed on lettuces (open leaf } \\
\text { varieties) compliant with GAP (EFSA, 2009a; } \\
\text { Austria 2013). Extrapolation to other } \\
\text { lettuces and fresh herbs is applicable. } \\
\text { MRL } \\
\text { OECD }=2.93\end{array}$ & 3 & 1.60 & 0.49 & - \\
\hline & SEU & $\begin{array}{l}0.10 ; 0.66 ; 0.83 ; 0.96 ; 0.98 ; 1.3 ; 1.9 ; \\
2.2\end{array}$ & $\begin{array}{l}\text { Trials performed on lettuces (open leaf } \\
\text { varieties) compliant with GAP (Austria, } \\
\text { 2013). Extrapolation to whole salad plants } \\
\text { group and fresh herbs is applicable. GAP for } \\
\text { lamb's lettuce is not authorised in the SEU. } \\
\text { MRL } \\
\text { OECD }=3.82\end{array}$ & 4 & 2.20 & 0.97 & - \\
\hline $\begin{array}{l}\text { Lettuces } \\
\text { Escaroles } \\
\text { Roman rocket/rucola } \\
\text { Red mustards } \\
\text { Baby leaf crops } \\
\text { Chards }\end{array}$ & EU & $0.93 ; 1.3 ; 1.8 ; 2.5 ; 3.0 ; 3.2 ; 3.2 ; 3.30$ & $\begin{array}{l}\text { Trials performed on lettuces (open leaf } \\
\text { varieties) compliant with GAP (EFSA, } \\
\text { 2009a). Extrapolation to escaroles, roman } \\
\text { rocket, red mustard, baby leaf crops and } \\
\text { chards is applicable. } \\
\text { MRL } \\
\text { OECD }=7.21\end{array}$ & 8 & 3.3 & 2.75 & - \\
\hline
\end{tabular}




\begin{tabular}{|c|c|c|c|c|c|c|c|}
\hline Crop & $\begin{array}{l}\text { Region/ } \\
\text { indoor }^{(a)}\end{array}$ & $\begin{array}{l}\text { Residue levels observed in the } \\
\text { supervised residue trials relevant } \\
\text { to the supported GAPs ( } \mathrm{mg} / \mathrm{kg} \text { ) }\end{array}$ & $\begin{array}{l}\text { Recommendations/comments } \\
\text { (OECD calculations) }\end{array}$ & $\begin{array}{c}\text { MRL } \\
\text { proposals } \\
(\mathrm{mg} / \mathrm{kg})\end{array}$ & $\begin{array}{l}\mathrm{HR}_{\text {Mo }} \\
(\mathbf{m g} / \\
\mathbf{k g})^{(\mathbf{b})}\end{array}$ & $\begin{array}{l}\text { STMR }_{\text {Mo }} \\
(\mathbf{m g} / \\
\mathbf{k g})^{(\mathrm{c})}\end{array}$ & $\mathrm{CF}^{(\mathrm{d})}$ \\
\hline $\begin{array}{l}\text { Lamb's lettuces } \\
\text { Cresses } \\
\text { Land cresses } \\
\text { Spinaches } \\
\text { Purslanes } \\
\text { Fresh herbs }\end{array}$ & EU & $1.8 ; 2.7 ; 3.3 ; 4.9 ; 5.4 ; 6.0 ; 6.2 ; 7.1$ & $\begin{array}{l}\text { Trials performed on lettuces (open leaf } \\
\text { varieties) compliant with GAP (Greece, } \\
\text { 2017). Extrapolation to lamb's lettuces, } \\
\text { cresses, land cresses, spinaches, purslanes } \\
\text { and fresh herbs is applicable. } \\
\text { MRL }\end{array}$ & 15 & 7.10 & 5.15 & - \\
\hline Hops & NEU & $19.6 ; 14 ; 2 \times 26 ; 31 ; 32 ; 2 \times 34$ & $\begin{array}{l}\text { Trials compliant with GAP (EFSA, 2011). } \\
\text { MRL } \\
\text { OECD }=81.22\end{array}$ & 90 & 34.0 & 28.5 & - \\
\hline
\end{tabular}

GAP: Good Agricultural Practice; OECD: Organisation for Economic Co-operation and Development; MRL: maximum residue level

*: Indicates that the MRL is proposed at the limit of quantification.

(a): NEU: Outdoor trials conducted in northern Europe, SEU: Outdoor trials conducted in southern Europe, Indoor: indoor EU trials or Country code: if non-EU trials.

(b): Highest residue.

(c): Supervised trials median residue.

(d): Conversion factor for risk assessment.

(e): Conversion factor derived from residue trials on potatoes where mandipropamid and SYN 500003 were analysed.

(f): MRL is tentative because toxicological information on the metabolite SYN 500003 is missing. 


\section{B.1.2.2. Residues in succeeding crops}

\begin{tabular}{|l|l|}
\hline $\begin{array}{l}\text { Confined rotational crop study } \\
\text { (quantitative aspect) }\end{array}$ & No residues are expected in rotational crops. \\
\hline Field rotational crop study & Not available and not required. \\
\hline
\end{tabular}

\section{B.1.2.3. Processing factors}

\section{Processed commodity}

\begin{tabular}{|c|c|c|c|}
$\begin{array}{c}\text { Number } \\
\text { of } \\
\text { studies }^{(a)}\end{array}$ & Individual values & Median PF & CF \\
\hline
\end{tabular}

\section{Robust processing factors (sufficiently supported by data)}

\begin{tabular}{l|l|l|l|l}
\hline Grape/pomace (wet) & 21 & (range 1.6-6.0) & 3.7 & 1 \\
\hline Grape/pomace (dry) & 21 & (range 6-23) & 13 & 1 \\
\hline Grape/red wine (maceration) & 21 & (range 0.06-0.38) & 0.20 & 1 \\
\hline Grape/juice & 25 & (range 0.18-0.75) & 0.50 & 1 \\
\hline Grape/raisin (sun drying) & 5 & $2.1,3.3,3.9,4.4,7.6$ & 3.9 & 1 \\
\hline Tomato/washed tomato & 4 & $0.19,0.25,0.28,0.50$ & 0.27 & 1 \\
\hline Tomato/juice & 4 & $0.86,0.92,1.03,1.25$ & 0.97 & 1 \\
\hline Tomato/wet pomace & 4 & $0.83,0.92,0.97,1.28$ & 0.94 & 1 \\
\hline Tomato/tomato puree & 4 & $0.94,1.14,1.14,1.36$ & 1.14 & 1 \\
\hline Tomato/canned tomato & 4 & $0.31,0.33,0.39,0.50$ & 0.36 & 1 \\
\hline Hops/beer & 4 & - & 0.0023 & 1 \\
\hline Limited processing factors (not sufficiently supported by data) & & \\
\hline Potato/fried & 2 & $0.05 ; 0.11$ & 0.08 & $1.6^{(\mathrm{b})}$ \\
\hline Potato/crisps (chips) & 2 & $0.03 ; 0.11$ & 0.07 & $2.0^{(\mathrm{b})}$ \\
\hline Potato/granules or flakes & 2 & $0.03 ; 0.11$ & 0.07 & $2.2^{(\mathrm{b})}$ \\
\hline Potato/process waste (wet peel) & 2 & $1.1 ; 3.0$ & 2.0 & $1.0^{(\mathrm{b})}$ \\
\hline Grape/red wine (must heated) & 1 & 0.09 & 0.09 & 1 \\
\hline
\end{tabular}

(a): Studies with residues in the RAC at or close to the LOQ were disregarded (unless concentration may occur).

(b): Conversion factor for risk assessment in the processed commodity; median of the individual conversion factors for each residues trial (Greece, 2017).

\section{B.2. Residues in livestock}

\begin{tabular}{|c|c|c|c|c|c|c|c|}
\hline \multirow{3}{*}{$\begin{array}{l}\text { Relevant } \\
\text { groups }\end{array}$} & \multicolumn{4}{|c|}{ Dietary burden expressed in } & \multirow{3}{*}{$\begin{array}{l}\text { Most critical } \\
\text { diet }^{(a)}\end{array}$} & \multirow{3}{*}{$\begin{array}{l}\text { Most critical } \\
\text { commodity }^{(a)}\end{array}$} & \multirow{3}{*}{$\begin{array}{l}\text { Trigger } \\
\text { exceeded } \\
(\mathrm{Y} / \mathrm{N})\end{array}$} \\
\hline & \multicolumn{2}{|c|}{$\begin{array}{c}\text { mg/kg bw per } \\
\text { day }\end{array}$} & \multicolumn{2}{|c|}{ mg/kg DM } & & & \\
\hline & Med. & Max. & Med. & Max. & & & \\
\hline $\begin{array}{l}\text { Cattle } \\
\text { (all diets) }\end{array}$ & 0.0031 & 0.0031 & 0.097 & 0.097 & Cattle (dairy) & Potato, process waste & No \\
\hline $\begin{array}{l}\text { Cattle } \\
\text { (dairy only) }\end{array}$ & 0.0031 & 0.0031 & 0.080 & 0.080 & Cattle (dairy) & Potato, process waste & No \\
\hline $\begin{array}{l}\text { Sheep } \\
\text { (all diets) }\end{array}$ & 0.0032 & 0.0032 & 0.097 & 0.097 & Sheep (ram/ewe) & Potato, process waste & No \\
\hline $\begin{array}{l}\text { Sheep } \\
\text { (ewe only) }\end{array}$ & 0.0032 & 0.0032 & 0.097 & 0.097 & Sheep (ram/ewe) & Potato, process waste & No \\
\hline $\begin{array}{l}\text { Swine } \\
\text { (all diets) }\end{array}$ & 0.0019 & 0.0019 & 0.083 & 0.083 & Swine (breeding) & Potato, process waste & No \\
\hline $\begin{array}{l}\text { Poultry } \\
\text { (all diets) }\end{array}$ & 0.0014 & 0.0014 & 0.020 & 0.020 & Poultry (turkey) & Potato, culls & No \\
\hline $\begin{array}{l}\text { Poultry } \\
\text { (layer only) }\end{array}$ & 0.0009 & 0.0009 & 0.013 & 0.013 & Poultry (layer) & Potato, culls & No \\
\hline
\end{tabular}

(a): Calculated for the maximum dietary burden. 


\section{B.2.1. Nature of residues and methods of analysis in livestock}

\section{B.2.1.1. Metabolism studies, methods of analysis and residue definitions in livestock}

\begin{tabular}{l|l|c|c|l}
\hline $\begin{array}{l}\text { Livestock } \\
\text { (available studies) }\end{array}$ & Animal & $\begin{array}{c}\text { Dose (mg/kg bw } \\
\text { per day) }\end{array}$ & $\begin{array}{c}\text { Duration } \\
\text { (days) }\end{array}$ & N rate/comment \\
\cline { 2 - 5 } & Lactating goat & $0.88-1.54$ & 7 & $284-469$ (compared to sheep) \\
\cline { 2 - 5 } & Laying hen & 1.39 & 14 & 992 (compared to poultry all diets) \\
\cline { 2 - 5 } & Source: EFSA, 2012; Greece, 2017. & & \\
\hline
\end{tabular}

\begin{tabular}{|l|l|}
\hline $\begin{array}{l}\text { Time needed to reach a plateau concentration in milk } \\
\text { and eggs (days) }\end{array}$ & $\begin{array}{l}\text { Milk: } 3 \text { days } \\
\text { Eggs: } 9 \text { days }\end{array}$ \\
\hline Metabolism in rat and ruminant similar (Yes/No) & Yes \\
\hline Animal residue definition for monitoring (RD-Mo) & Not required \\
\hline Animal residue definition for risk assessment (RD-RA) & Not required \\
\hline Conversion factor (monitoring to risk assessment) & Not applicable \\
\hline Fat soluble residues (Yes/No) & No \\
\hline $\begin{array}{l}\text { Methods of analysis for monitoring of residues } \\
\text { (analytical technique, crop groups, LOQs) }\end{array}$ & $\begin{array}{r}\text { LC-MS/MS (Austria, 2013; Greece, 2017): } \\
\text { LOQ of 0.01 mg/kg (beef meat, fat, kidney, } \\
\text { liver, milk and chicken meat, fat, kidney, liver } \\
\text { and eggs) } \\
\text { ILV available. }\end{array}$ \\
\hline
\end{tabular}

\section{B.2.1.2. Stability of residues in livestock}

\begin{tabular}{l|l|l|l|l}
\hline $\begin{array}{l}\text { Animal products } \\
\text { (available studies) }\end{array}$ & Animal & Commodity & T ( $\left.{ }^{\circ} \mathbf{C}\right)$ & Stability (Months/years) \\
\cline { 2 - 5 } & - & Muscle & - & - \\
\hline & - & Liver & - & - \\
\hline & - & Kidney & - & - \\
\hline & - & Milk & - & - \\
\hline & Egg & - & - \\
\hline & No data available. & & \\
\hline
\end{tabular}

\section{B.2.2. Magnitude of residues in livestock}

\section{B.2.2.1. Summary of the residue data from livestock feeding studies}

MRLs are not necessary as the dietary burdens were found to be below the trigger value. 


\section{B.3. Consumer risk assessment}

\section{B.3.1. Consumer risk assessment without consideration of the existing CXLs}

\begin{tabular}{|l|l|}
\hline ADI & $0.15 \mathrm{mg} / \mathrm{kg}$ bw per day $(\mathrm{EFSA}, 2012)$ \\
\hline $\begin{array}{l}\text { Highest IEDI, according to } \\
\text { EFSA PRIMo }\end{array}$ & $2.8 \% \mathrm{ADI}(\mathrm{FR}$, toddler) \\
\hline $\begin{array}{l}\text { Assumptions made for the } \\
\text { calculations }\end{array}$ & $\begin{array}{l}\text { The calculation is based on the median residue levels in the raw agricultural } \\
\text { commodities. A conversion factor }(\mathrm{CF}=2) \text { from the residue trials performed on } \\
\text { potatoes was applied to potatoes. } \\
\text { The contributions of commodities where no GAP was reported in the framework } \\
\text { of this review were not included in the calculation. }\end{array}$ \\
\hline
\end{tabular}

\begin{tabular}{|l|l|}
\hline ARfD & Not applicable (EFSA, 2012) \\
\hline Highest IESTI, according to EFSA PRIMo & - \\
\hline Assumptions made for the calculations & - \\
\hline
\end{tabular}

ADI: acceptable daily intake; bw: body weight; IEDI: international estimated daily intake; PRIMo: (EFSA) Pesticide Residues Intake Model; WHO: World Health Organization; ARfD: acute reference dose; IESTI: international estimated short-term intake.

\section{B.3.2. Consumer risk assessment with consideration of the existing CXLs}

\begin{tabular}{|l|l|}
\hline ADI & $0.15 \mathrm{mg} / \mathrm{kg}$ bw per day (EFSA, 2012) \\
\hline $\begin{array}{l}\text { Highest IEDI, according to } \\
\text { EFSA PRIMo }\end{array}$ & $5.0 \%$ ADI (NL, child) \\
\hline $\begin{array}{l}\text { Assumptions made for the } \\
\text { calculations }\end{array}$ & $\begin{array}{l}\text { The calculation is based on the median residue levels in the raw agricultural } \\
\text { commodities. A conversion factor }(\mathrm{CF}=2) \text { from the residue trials performed on } \\
\text { potatoes was applied to potatoes, onions and spring onions. } \\
\text { The contributions of commodities where no GAP was reported in the framework } \\
\text { of this review were not included in the calculation }\end{array}$ \\
\hline
\end{tabular}

\begin{tabular}{|l|l|}
\hline ARfD & Not applicable (EFSA, 2012) \\
\hline Highest IESTI, according to EFSA PRIMo & - \\
\hline Assumptions made for the calculations & - \\
\hline
\end{tabular}

\section{B.4. $\quad$ Proposed MRLs}

\begin{tabular}{l|l|l|c|c|l}
\hline $\begin{array}{l}\text { Code } \\
\text { number }\end{array}$ & Commodity & $\begin{array}{c}\text { Existing EU } \\
\text { MRL } \\
(\mathbf{m g} / \mathbf{k g})\end{array}$ & $\begin{array}{c}\text { Existing } \\
\text { CXL } \\
(\mathbf{m g} / \mathbf{k g})\end{array}$ & $\begin{array}{c}\text { Outcome of the review } \\
(\mathbf{m g} / \mathbf{k g})\end{array}$ & Comment \\
\hline
\end{tabular}

Enforcement residue definition (existing): mandipropamid (sum of isomers)

Enforcement residue definition (proposed): mandipropamid (any ratio of constituent isomers)

\begin{tabular}{|l|l|l|l|l|l|}
\hline 151010 & Table grapes & 2 & 2 & 2 & Recommended $^{(\mathrm{a})}$ \\
\hline 151020 & Wine grapes & 2 & 2 & 2 & Recommended $^{(\mathrm{a})}$ \\
\hline 211000 & Potatoes & $0.01^{*}$ & $0.01^{*}$ & $0.01^{*}$ & Further consideration needed $^{(\mathrm{b})}$ \\
\hline 220020 & Onions & 0.1 & 0.1 & 0.1 & Further consideration needed $^{(\mathrm{c})}$ \\
\hline 220040 & Spring onions & 7 & 7 & 7 & Further consideration needed $^{(\mathrm{c})}$ \\
\hline 231010 & Tomatoes & 3 & 0.3 & 3 & Recommended $^{(\mathrm{d})}$ \\
\hline 231020 & Peppers & 1 & 1 & 1 & Recommended $^{(\mathrm{e})}$ \\
\hline 231030 & Aubergines/eggplants & 1 & - & 3 & Recommended $^{(\mathrm{f})}$ \\
\hline 232010 & Cucumbers & 0.2 & 0.2 & 0.2 & Recommended $^{(\mathrm{a})}$ \\
\hline
\end{tabular}




\begin{tabular}{|c|c|c|c|c|c|}
\hline \multirow{2}{*}{$\begin{array}{l}\text { Code } \\
\text { number }\end{array}$} & \multirow[b]{2}{*}{ Commodity } & \multirow{2}{*}{$\begin{array}{c}\text { Existing EU } \\
\text { MRL } \\
(\mathbf{m g} / \mathbf{k g})\end{array}$} & \multirow{2}{*}{$\begin{array}{c}\text { Existing } \\
\text { CXL } \\
(\mathrm{mg} / \mathrm{kg})\end{array}$} & \multicolumn{2}{|c|}{ Outcome of the review } \\
\hline & & & & $\begin{array}{c}\text { MRL } \\
(\mathbf{m g} / \mathbf{k g})\end{array}$ & Comment \\
\hline 232030 & Courgettes & 0.2 & 0.2 & 0.2 & Recommended $^{(a)}$ \\
\hline 233010 & Melons & 0.5 & 0.5 & 0.5 & Recommended $^{(a)}$ \\
\hline 233020 & Pumpkins & 0.3 & - & 0.3 & Recommended $^{(\mathrm{f})}$ \\
\hline 241010 & Broccoli & 2 & 2 & 2 & Recommended $^{(e)}$ \\
\hline 242020 & Head cabbage & 3 & 3 & 3 & Recommended $^{(\mathrm{e})}$ \\
\hline 243010 & Chinese cabbage & 25 & 25 & 25 & Recommended $^{(e)}$ \\
\hline 243020 & Kale & 25 & 25 & 25 & Recommended $^{(e)}$ \\
\hline 251010 & $\begin{array}{l}\text { Lamb's lettuces/corn } \\
\text { salads }\end{array}$ & 25 & 25 & 25 & Recommended $^{(\mathrm{a})}$ \\
\hline 251020 & Lettuces & 25 & 25 & 25 & Recommended $^{(a)}$ \\
\hline 251030 & $\begin{array}{l}\text { Escaroles/broad-leaved } \\
\text { endives }\end{array}$ & 25 & 25 & 25 & Recommended $^{(\mathrm{a})}$ \\
\hline 251040 & $\begin{array}{l}\text { Cresses and other } \\
\text { sprouts and shoots }\end{array}$ & 25 & 25 & 25 & Recommended $^{(a)}$ \\
\hline 251050 & Land cresses & 25 & 25 & 25 & Recommended $^{(a)}$ \\
\hline 251060 & Roman rocket/rucola & 25 & 25 & 25 & Recommended $^{(a)}$ \\
\hline 251070 & Red mustards & 25 & 25 & 25 & Recommended $^{(a)}$ \\
\hline 251080 & $\begin{array}{l}\text { Baby leaf crops } \\
\text { (including brassica } \\
\text { species) }\end{array}$ & 25 & 25 & 25 & Recommended $^{(a)}$ \\
\hline 252010 & Spinaches & 25 & 25 & 25 & Recommended $^{(a)}$ \\
\hline 252020 & Purslanes & 25 & 25 & 25 & Recommended $^{(a)}$ \\
\hline 252030 & Chards/beet leaves & 25 & 25 & 25 & Recommended $^{(a)}$ \\
\hline 253000 & $\begin{array}{l}\text { Vine leaves (grape } \\
\text { leaves) }\end{array}$ & $0.01 *$ & 25 & 25 & Recommended $^{(\mathrm{e})}$ \\
\hline 254000 & Water cress & 25 & 25 & 25 & Recommended $^{(e)}$ \\
\hline 255000 & Witloof & $0.01 *$ & 25 & 25 & Recommended $^{(e)}$ \\
\hline 256010 & Chervil & 10 & 25 & 25 & Recommended $^{(a)}$ \\
\hline 256020 & Chives & 10 & - & 15 & Recommended $^{(f)}$ \\
\hline 256030 & Celery leaves & 10 & - & 15 & Recommended $^{(f)}$ \\
\hline 256040 & Parsley & 10 & - & 15 & Recommended $^{(f)}$ \\
\hline 256050 & Sage & 10 & - & 15 & Recommended $^{(f)}$ \\
\hline 256060 & Rosemary & 10 & - & 15 & Recommended $^{(f)}$ \\
\hline 256070 & Thyme & 10 & - & 15 & Recommended $^{(\mathrm{f})}$ \\
\hline 256080 & $\begin{array}{l}\text { Basil and edible } \\
\text { flowers }\end{array}$ & 10 & - & 15 & Recommended $^{(\mathrm{f})}$ \\
\hline 256090 & Laurel/bay leave & 10 & - & 15 & Recommended $^{(\mathrm{f})}$ \\
\hline 256100 & Tarragon & 10 & - & 15 & Recommended $^{(\mathrm{f})}$ \\
\hline 270030 & Celery & 20 & 20 & 20 & Recommended $^{(e)}$ \\
\hline 700000 & Hops & 90 & 90 & 90 & Recommended $^{(\mathrm{d})}$ \\
\hline- & $\begin{array}{l}\text { Other commodities of } \\
\text { plant/animal origin }\end{array}$ & $\begin{array}{l}\text { See Reg. (EU) } \\
2015 / 845\end{array}$ & - & - & Further consideration needed $^{(\mathrm{g})}$ \\
\hline
\end{tabular}

MRL: maximum residue level; CXL: codex maximum residue limit.

*: Indicates that the MRL is set at the limit of quantification.

(a): MRL is derived from the existing CXL, which is supported by data and for which no risk to consumers is identified; GAP evaluated at EU level, which is also fully supported by data, leads to a lower MRL (combination G-VII in Appendix E).

(b): Tentative MRL is derived from a GAP evaluated at EU level, which is not fully supported by data but for which no risk to consumers was identified (assuming the existing residue definition); existing CXL is covered by the tentative MRL (combination E-III in Appendix E). 
(c): MRL is derived from the existing $C X L$, which is not sufficiently supported by data but for which no risk to consumers is identified (assuming the existing residue definition); there are no relevant authorisations or import tolerances reported at EU level (combination A-V in Appendix E).

(d): MRL is derived from a GAP evaluated at EU level, which is fully supported by data and for which no risk to consumers is identified; existing CXL is covered by the recommended MRL (combination G-III in Appendix E).

(e): MRL is derived from the existing $C X L$, which is supported by data and for which no risk to consumers is identified; there are no relevant authorisations or import tolerances reported at EU level (combination A-VII in Appendix E).

(f): MRL is derived from a GAP evaluated at EU level, which is fully supported by data and for which no risk to consumers is identified; no CXL is available (combination G-I in Appendix E).

(g): There are no relevant authorisations or import tolerances reported at EU level; no CXL is available. Either a specific LOQ or the default MRL of $0.01 \mathrm{mg} / \mathrm{kg}$ may be considered (combination A-I in Appendix E). 


\section{Appendix C - Pesticide Residue Intake Model (PRIMo)}

- $\operatorname{PRIMo}(E U)$

\begin{tabular}{|c|c|c|c|}
\hline \multicolumn{4}{|c|}{ Mandipropamid } \\
\hline 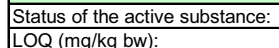 & & $\begin{array}{l}\text { Code no. } \\
\text { Proposed LC }\end{array}$ & \\
\hline & Toxicological en & d points & \\
\hline $\begin{array}{l}\text { ADI (molkg bw per day): } \\
\text { Source of ADI: } \\
\text { Year of evaluation: }\end{array}$ & $\begin{array}{l}0.15 \\
\text { EFSA } \\
2012\end{array}$ & 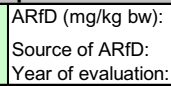 & $\begin{array}{l}\text { n.n. } \\
\text { EFSA } \\
2012\end{array}$ \\
\hline
\end{tabular}

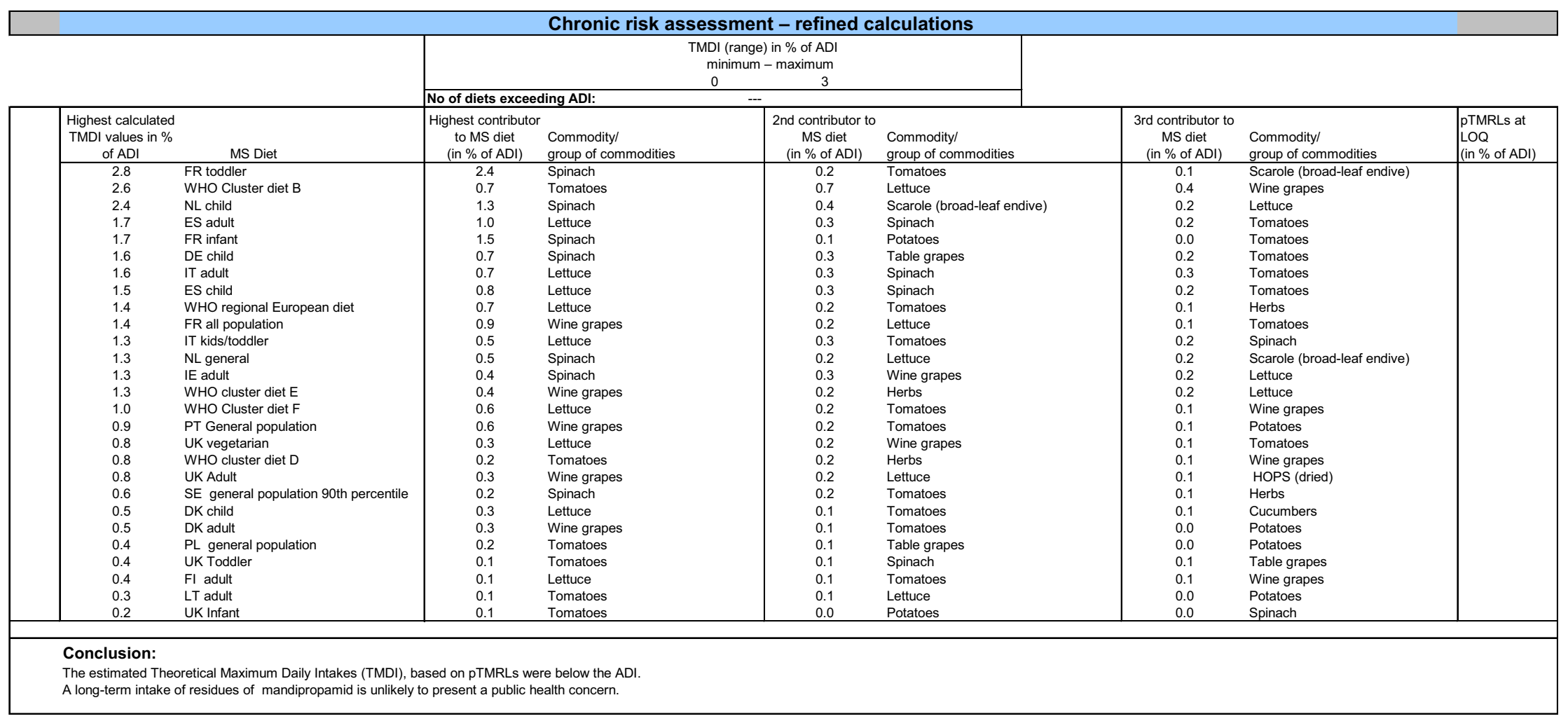




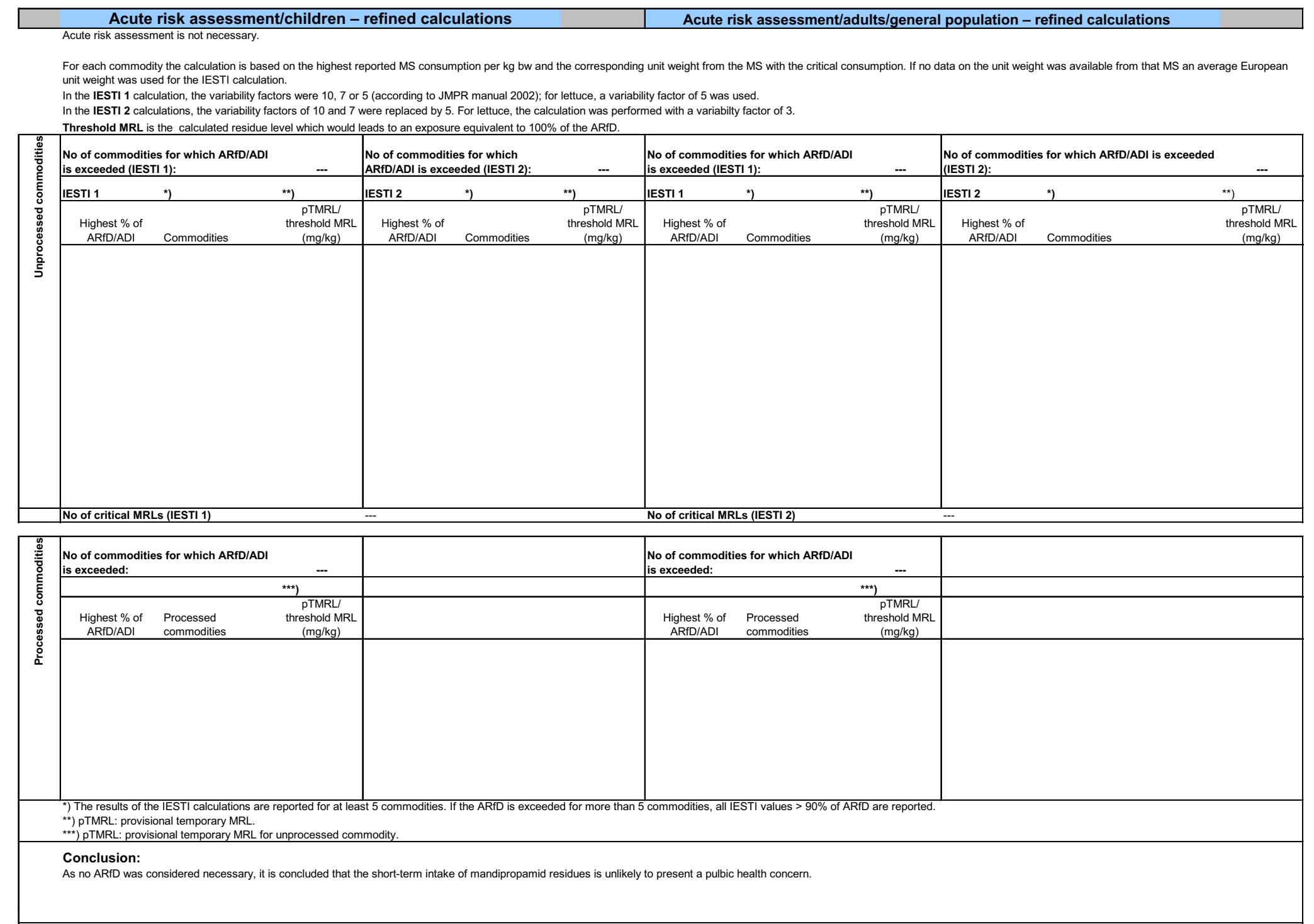


- $\operatorname{PRIMo}(C X L)$

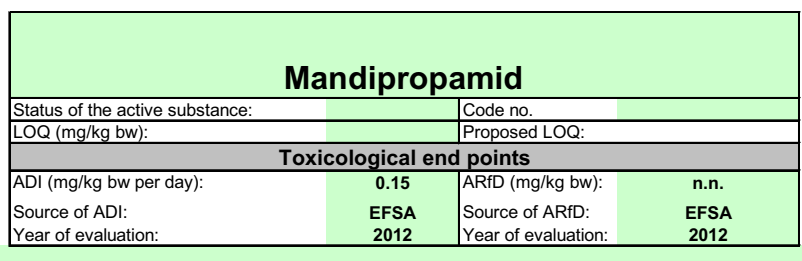

\begin{tabular}{|c|c|c|c|c|c|c|c|c|}
\hline \multicolumn{9}{|c|}{ Chronic risk assessment - refined calculations } \\
\hline & & \multirow{2}{*}{\multicolumn{4}{|c|}{$\begin{array}{c}\text { TMDI (range) in \% of ADI } \\
\text { minimum - maximum } \\
0\end{array}$}} & & & \\
\hline & & & & & & & & \\
\hline \multicolumn{2}{|l|}{\begin{tabular}{|l} 
Highest calculated \\
TMDI values in \%
\end{tabular}} & $\begin{array}{l}\text { Highest contibut } \\
\text { to MS diet }\end{array}$ & Commodityl & \multicolumn{2}{|c|}{$\begin{array}{l}\text { 2nd contributor to } \\
\text { MS commodity }\end{array}$} & 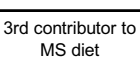 & Commod & \multirow{2}{*}{$\begin{array}{l}\text { pTMRLs at } \\
\text { LoQ } \\
\text { (in \% of ADI) }\end{array}$} \\
\hline \begin{tabular}{|l|l} 
of $A D I$ \\
550 \\
\end{tabular} & $\begin{array}{l}\text { MS Diet } \\
\text { NL child }\end{array}$ & \begin{tabular}{|l|l|l|} 
(in \% of ADI) \\
1.4
\end{tabular} & $\begin{array}{l}\text { group of commodities } \\
\text { Spinach }\end{array}$ & (in \% of ADD) & $\begin{array}{l}\text { group of com } \\
\text { Scarole (broa }\end{array}$ & $\frac{(i n \% \% ~ f A D l)}{0.7}$ & $\begin{array}{l}\text { group of commodities } \\
\text { Wittoof }\end{array}$ & \\
\hline 4.4 & WHO Cluster diet B & 1.3 & Lettuce & 0.7 & Tomatoes & 0.6 & Wine grapes & \\
\hline 3.6. & $\begin{array}{l}\text { II Rult population } \\
\text { F R Pll }\end{array}$ & 1.4. & $\begin{array}{l}\text { Letuce } \\
\text { Wine grapes } \\
\text { cines }\end{array}$ & 0.7 & 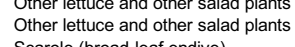 & 0.5 & 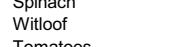 & \\
\hline 3.4. & $\begin{array}{l}\text { FR toddder } \\
\text { NL general }\end{array}$ & $\begin{array}{l}2.7 \\
0.6\end{array}$ & $\begin{array}{l}\text { Spinach } \\
\text { Wittoof }\end{array}$ & $\begin{array}{l}0.2 \\
0.5\end{array}$ & $\begin{array}{l}\text { Scarale (broad-leaf endive) } \\
\text { Spinach }\end{array}$ & $\begin{array}{l}0.2 \\
0.5\end{array}$ & $\begin{array}{l}\begin{array}{l}\text { Tomataes } \\
\text { Lettuce }\end{array} \\
\text { nats }\end{array}$ & \\
\hline $\begin{array}{l}3.1 \\
3.0\end{array}$ & $\begin{array}{l}\text { ES adult } \\
\text { IE audit }\end{array}$ & 0.8 & $\begin{array}{l}\text { Lettuce } \\
\text { Other leary brassica }\end{array}$ & $\begin{array}{l}0.3 \\
0.5\end{array}$ & $\begin{array}{l}\text { Beet leaves (hard) } \\
\text { Spinach }\end{array}$ & $\begin{array}{l}0.3 \\
0.4\end{array}$ & $\begin{array}{l}\text { Spinach } \\
\text { Wing grapes }\end{array}$ & \\
\hline 2.9 & $\begin{array}{l}\text { WHO regional European diet } \\
\text { TT kidstiddlder }\end{array}$ & 1.4 & $\begin{array}{l}\text { Lettuce } \\
\text { Letuluce }\end{array}$ & 0.3 & $\begin{array}{l}\text { Head cabbage } \\
\text { Oother eltuce and other }\end{array}$ & 0.2 & $\begin{array}{l}\text { Tomatoes } \\
\text { TTomatees }\end{array}$ & \\
\hline 2.7. & $\begin{array}{l}\text { TI kidsfotoder } \\
\text { WHO cluster diet D }\end{array}$ & $\begin{array}{l}1.1 \\
0.7\end{array}$ & $\begin{array}{l}\text { Letuce chabage } \\
\text { Chinese cabbge }\end{array}$ & $\begin{array}{l}0.4 \\
0.3\end{array}$ & $\begin{array}{l}\text { OOther ettuce and ofher } \\
\text { Kale }\end{array}$ & $\begin{array}{l}0.3 \\
0.3\end{array}$ & $\begin{array}{l}\text { Tomatoes } \\
\text { Kale }\end{array}$ & \\
\hline 2.6 & $\begin{array}{l}\text { ES hild } \\
\text { WHO Cluster diet } F\end{array}$ & $\begin{array}{l}1.6 \\
1.1\end{array}$ & $\begin{array}{l}\text { Lettuce } \\
\text { Lettuce }\end{array}$ & $\begin{array}{l}0.3 \\
0.2\end{array}$ & $\begin{array}{l}\text { Spiniach } \\
\text { Chinese cabbage }\end{array}$ & $\begin{array}{l}0.3 \\
0.2\end{array}$ & $\begin{array}{l}\text { Beeel leaves (chard) } \\
\text { Head cabbage }\end{array}$ & \\
\hline $\begin{array}{l}2.3 \\
2.3\end{array}$ & $\begin{array}{l}\text { WHO cluster diet } \mathrm{E} \\
\text { DE child }\end{array}$ & 0.5 & $\begin{array}{l}\text { Wine grapes } \\
\text { Sppinach }\end{array}$ & 0.3 & $\begin{array}{l}\text { Lettuce } \\
\text { Tabale erapes }\end{array}$ & 0.2 & $\begin{array}{l}\text { Head cabbage } \\
\text { Lettue }\end{array}$ & \\
\hline 2.3 .2 & $\begin{array}{l}\text { SE general population 9oth percentile } \\
\text { FR infant }\end{array}$ & 0.8 & $\begin{array}{l}\text { Chinese cabbage } \\
\text { Soinach }\end{array}$ & 0.3 .5 & $\begin{array}{l}\text { Head cabbage } \\
\text { wititof bage }\end{array}$ & $\begin{array}{l}0.3 \\
0.3\end{array}$ & $\begin{array}{l}\text { Spinach } \\
\text { Brococoli }\end{array}$ & \\
\hline $\begin{array}{l}1.4 \\
1.3\end{array}$ & $\begin{array}{l}\text { UKk vegetaraian } \\
\text { UK Kadut }\end{array}$ & $\begin{array}{l}0.5 \\
0.4\end{array}$ & $\begin{array}{l}\text { Letruc } \\
\text { Leturece }\end{array}$ & $\begin{array}{l}0.3 \\
0.4\end{array}$ & $\begin{array}{l}\text { Wine grapes } \\
\text { Wing grapes }\end{array}$ & $\begin{array}{l}0.1 \\
0.1\end{array}$ & $\begin{array}{l}\text { Tomatios } \\
\text { Tomeses) } \\
\text { Hos (dried) }\end{array}$ & \\
\hline 1.3 & 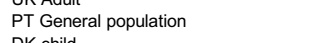 & 0.8 & $\begin{array}{l}\text { Wint grapes } \\
\text { w }\end{array}$ & 0.2 & $\begin{array}{l}\text { Whing grapes } \\
\text { TTmatoes }\end{array}$ & 0.1 & $\begin{array}{l}\text { Hobs grnead } \\
\text { Table grapes }\end{array}$ & \\
\hline $\begin{array}{l}0.9 \\
0.9\end{array}$ & $\begin{array}{l}\text { DK chidd ral population } \\
\text { PL genera pulate }\end{array}$ & $\begin{array}{l}0.5 \\
0.3 \\
0.3\end{array}$ & $\begin{array}{l}\text { Lettucea } \\
\text { Head cabbage }\end{array}$ & $\begin{array}{l}0.1 \\
0.2\end{array}$ & $\begin{array}{l}\text { Tomatoes } \\
\text { Tomatoes }\end{array}$ & $\begin{array}{l}0.1 \\
0.1\end{array}$ & $\begin{array}{l}\text { Tabb grapes } \\
\text { Table grapes }\end{array}$ & \\
\hline $\begin{array}{l}0.8 \\
0.8\end{array}$ & $\begin{array}{l}\text { DF adult } \\
\text { FI adult }\end{array}$ & $\begin{array}{l}0.5 \\
0.3\end{array}$ & $\begin{array}{l}\text { Wing grapes } \\
\text { Lettuce }\end{array}$ & $\begin{array}{l}0.1 \\
0.1\end{array}$ & $\begin{array}{l}\text { Tomatoes } \\
\text { Chinese cabbage }\end{array}$ & $\begin{array}{l}0.1 \\
0.1\end{array}$ & $\begin{array}{l}\text { Chinese cabbage } \\
\text { Wine grapes }\end{array}$ & \\
\hline 0.8 & $\begin{array}{l}\text { LT adult } \\
\text { UK Todder }\end{array}$ & $\begin{array}{l}0.3 \\
0.1\end{array}$ & $\begin{array}{l}\text { Head cabbage } \\
\text { Tomatoes }\end{array}$ & 0.2 & $\begin{array}{l}\text { Lettuce } \\
\text { spinach }\end{array}$ & 0.1 & $\begin{array}{l}\text { Tomatoes } \\
\text { Tata orapes }\end{array}$ & \\
\hline 0.3 & UK Intant & & $\begin{array}{l}\text { Tomatoes } \\
\text { Tol }\end{array}$ & & Head cabbage & 0.0 & $\begin{array}{l}\text { aobe grapes } \\
\text { Potatoes }\end{array}$ & \\
\hline
\end{tabular}




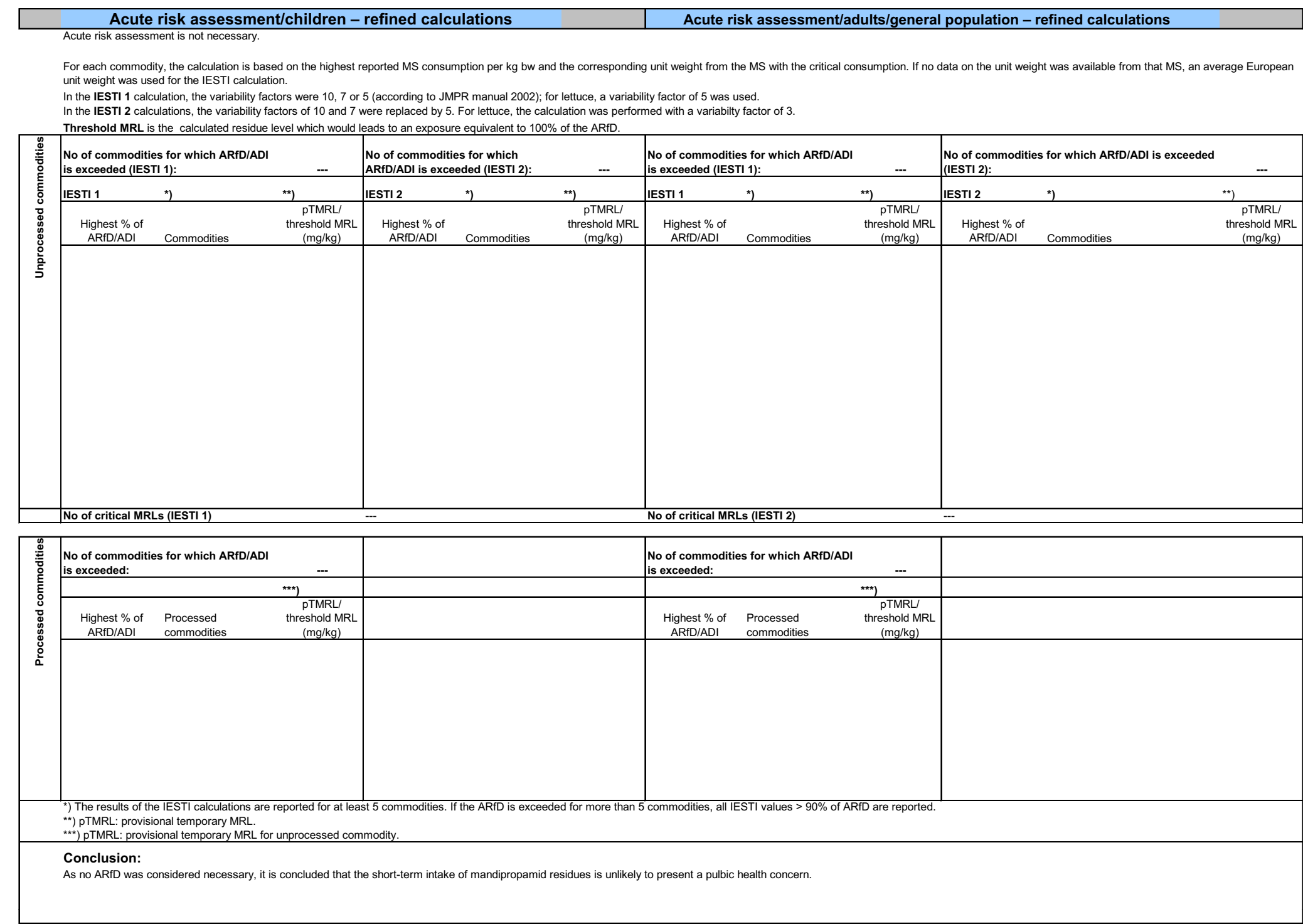




\section{Appendix D - Input values for the exposure calculations}

\section{D.1. Livestock dietary burden calculations}

\begin{tabular}{|l|c|l|c|c|}
\hline \multirow{2}{*}{ Feed commodity } & \multicolumn{2}{|c|}{ Median dietary burden } & \multicolumn{2}{c}{ Maximum dietary burden } \\
\cline { 2 - 5 } & $\begin{array}{c}\text { Input value } \\
(\mathbf{m g} / \mathbf{k g})\end{array}$ & Comment & $\begin{array}{c}\text { Input value } \\
(\mathbf{m g} / \mathbf{k g})\end{array}$ & Comment \\
\hline
\end{tabular}

Risk assessment residue definition - sum of mandipropamid and metabolite SYN 500003

[tentative; pending on the submission of toxicological information on SYN 500003]

\begin{tabular}{l|l|l|l|l}
\hline Potato, culls & 0.02 & STMR $\times$ CF (2) & 0.02 & HR $\times$ CF (2) \\
\hline Potato, process waste & 0.02 & STMR $\times$ PF $\times$ CF & 0.02 & STMR $\times$ PF $\times$ CF \\
\hline Potato, dried pulp & 0.02 & STMR $\times$ PF $\times$ CF & 0.02 & STMR $\times$ PF $\times$ CF \\
\hline
\end{tabular}

STMR: supervised trials median residue; HR: highest residue; PF: processing factor.

\section{D.2. Consumer risk assessment without consideration of the existing CXLs}

\section{Commodity}

Chronic risk assessment

Input value $\mathbf{( m g / k g})$ Comment

Risk assessment residue definition - sum of mandipropamid and metabolite SYN 500003 [tentative; pending on the submission of toxicological information on SYN 500003]
Potatoes
0.02 STMR (tentative) $\times$ CF

\begin{tabular}{|c|c|c|}
\hline \multicolumn{3}{|c|}{ Risk assessment residue definition - mandipropamid (any ratio of constituent isomers } \\
\hline Table grapes & 0.35 & STMR \\
\hline Wine grapes & 0.35 & STMR \\
\hline Tomatoes & 0.34 & STMR \\
\hline Aubergines/eggplants & 0.34 & STMR \\
\hline Cucumbers & 0.05 & STMR \\
\hline Courgettes & 0.05 & STMR \\
\hline Melons & 0.07 & STMR \\
\hline Pumpkins & 0.07 & STMR \\
\hline Lamb's lettuces/corn salads & 5.15 & STMR \\
\hline Lettuces & 2.75 & STMR \\
\hline Escaroles/broad-leaved endives & 2.75 & STMR \\
\hline Cresses and other sprouts and shoots & 5.15 & STMR \\
\hline Land cresses & 5.15 & STMR \\
\hline Roman rocket/rucola & 2.75 & STMR \\
\hline Red mustards & 2.75 & STMR \\
\hline Baby leaf crops (including brassica species) & 2.75 & STMR \\
\hline Spinaches & 5.15 & STMR \\
\hline Purslanes & 5.15 & STMR \\
\hline Chards/beet leaves & 2.75 & STMR \\
\hline Chervil & 5.15 & STMR \\
\hline Chives & 5.15 & STMR \\
\hline Celery leaves & 5.15 & STMR \\
\hline Parsley & 5.15 & STMR \\
\hline Sage & 5.15 & STMR \\
\hline Rosemary & 5.15 & STMR \\
\hline Thyme & 5.15 & STMR \\
\hline Basil and edible flowers & 5.15 & STMR \\
\hline Laurel/bay leave & 5.15 & STMR \\
\hline
\end{tabular}




\begin{tabular}{l|c|l}
\hline \multirow{2}{*}{ Commodity } & \multicolumn{2}{|c}{ Chronic risk assessment } \\
\cline { 2 - 3 } & Input value $\mathbf{( m g / k g )}$ & Comment \\
\hline Tarragon & 5.15 & STMR \\
\hline Hops & 28.50 & STMR \\
\hline
\end{tabular}

STMR: supervised trials median residue; CF: conversion factor.

\section{D.3. Consumer risk assessment with consideration of the existing CXLS}

\section{Commodity}

\section{Chronic risk assessment}

\section{Input value $(\mathbf{m g} / \mathbf{k g}) \quad$ Comment}

Risk assessment residue definition - sum of mandipropamid and metabolite SYN 500003 [tentative; pending on the submission of toxicological information on SYN 500003]

\begin{tabular}{l|l|l}
\hline Potatoes & 0.02 & STMR (tentative $) \times$ CF \\
\hline Onions & 0.02 & STMR $(C X L$, tentative $) \times C F$ \\
\hline Spring onions & 0.96 & STMR $(C X L$, tentative $) \times C F$ \\
\hline
\end{tabular}

\begin{tabular}{|c|c|c|}
\hline \multicolumn{3}{|c|}{ Risk assessment residue definition - mandipropamid (any ratio of constituent isomers) } \\
\hline Table grapes & 0.51 & STMR (CXL) \\
\hline Wine grapes & 0.51 & STMR (CXL) \\
\hline Tomatoes & 0.34 & STMR \\
\hline Peppers & 0.12 & STMR (CXL) \\
\hline Aubergines/eggplants & 0.34 & STMR \\
\hline Cucumbers & 0.02 & STMR (CXL) \\
\hline Courgettes & 0.04 & STMR (CXL) \\
\hline Melons & 0.12 & STMR (CXL) \\
\hline Pumpkins & 0.07 & STMR \\
\hline Broccoli & 0.44 & STMR (CXL) \\
\hline Head cabbage & 1.21 & STMR (CXL) \\
\hline Chinese cabbage & 5.65 & STMR (CXL) \\
\hline Kale & 5.65 & STMR (CXL) \\
\hline Lamb's lettuces/corn salads & 5.65 & STMR (CXL) \\
\hline Lettuces & 5.65 & STMR (CXL) \\
\hline Escaroles/broad-leaved endives & 5.65 & STMR (CXL) \\
\hline Cresses and other sprouts and shoots & 5.65 & STMR (CXL) \\
\hline Land cresses & 5.65 & STMR (CXL) \\
\hline Roman rocket/rucola & 5.65 & STMR (CXL) \\
\hline Red mustards & 5.65 & STMR (CXL) \\
\hline Baby leaf crops (including brassica species) & 5.65 & STMR (CXL) \\
\hline Spinaches & 5.65 & STMR (CXL) \\
\hline Purslanes & 5.65 & STMR (CXL) \\
\hline Chards/beet leaves & 5.65 & STMR (CXL) \\
\hline Vine leaves (grape leaves) & 5.65 & STMR (CXL) \\
\hline Water cress & 5.65 & STMR (CXL) \\
\hline Witloof & 5.65 & STMR (CXL) \\
\hline Chervil & 5.65 & STMR (CXL) \\
\hline Chives & 5.15 & STMR \\
\hline Celery leaves & 5.15 & STMR \\
\hline Parsley & 5.15 & STMR \\
\hline Sage & 5.15 & STMR \\
\hline Rosemary & 5.15 & STMR \\
\hline
\end{tabular}




\begin{tabular}{l|c|l}
\hline \multirow{2}{*}{ Commodity } & \multicolumn{2}{|c}{ Chronic risk assessment } \\
\cline { 2 - 3 } & Input value $\mathbf{( m g / k g )}$ & Comment \\
\hline Thyme & 5.15 & STMR \\
\hline Basil and edible flowers & 5.15 & STMR \\
\hline Laurel/bay leave & 5.15 & STMR \\
\hline Tarragon & 5.15 & STMR \\
\hline Celery & 2.70 & STMR (CXL) \\
\hline Hops & 28.50 & STMR \\
\hline
\end{tabular}

STMR: supervised trials median residue; CXL: codex maximum residue limit; CF: conversion factor. 


\section{Appendix E - Decision tree for deriving MRL recommendations}

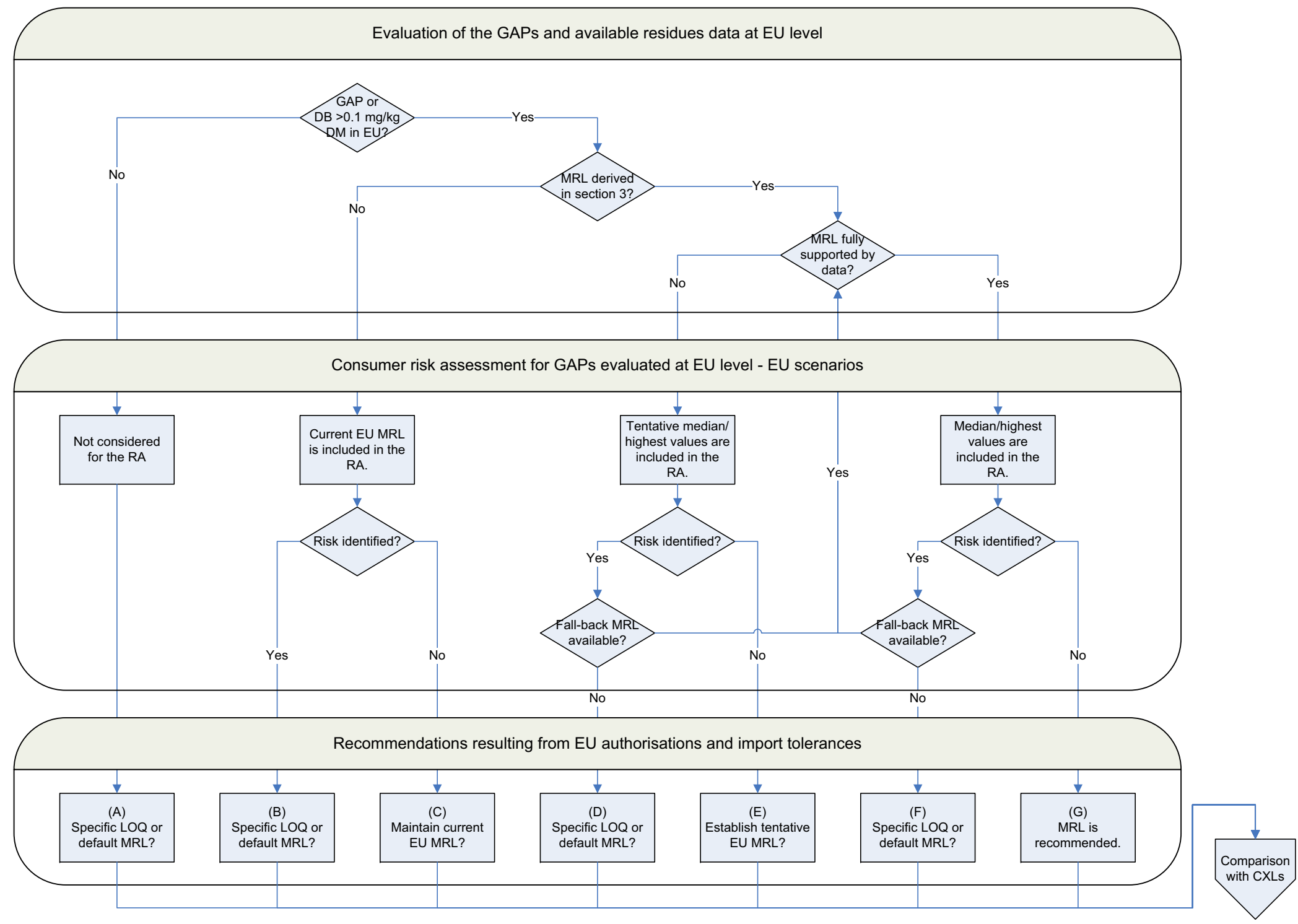




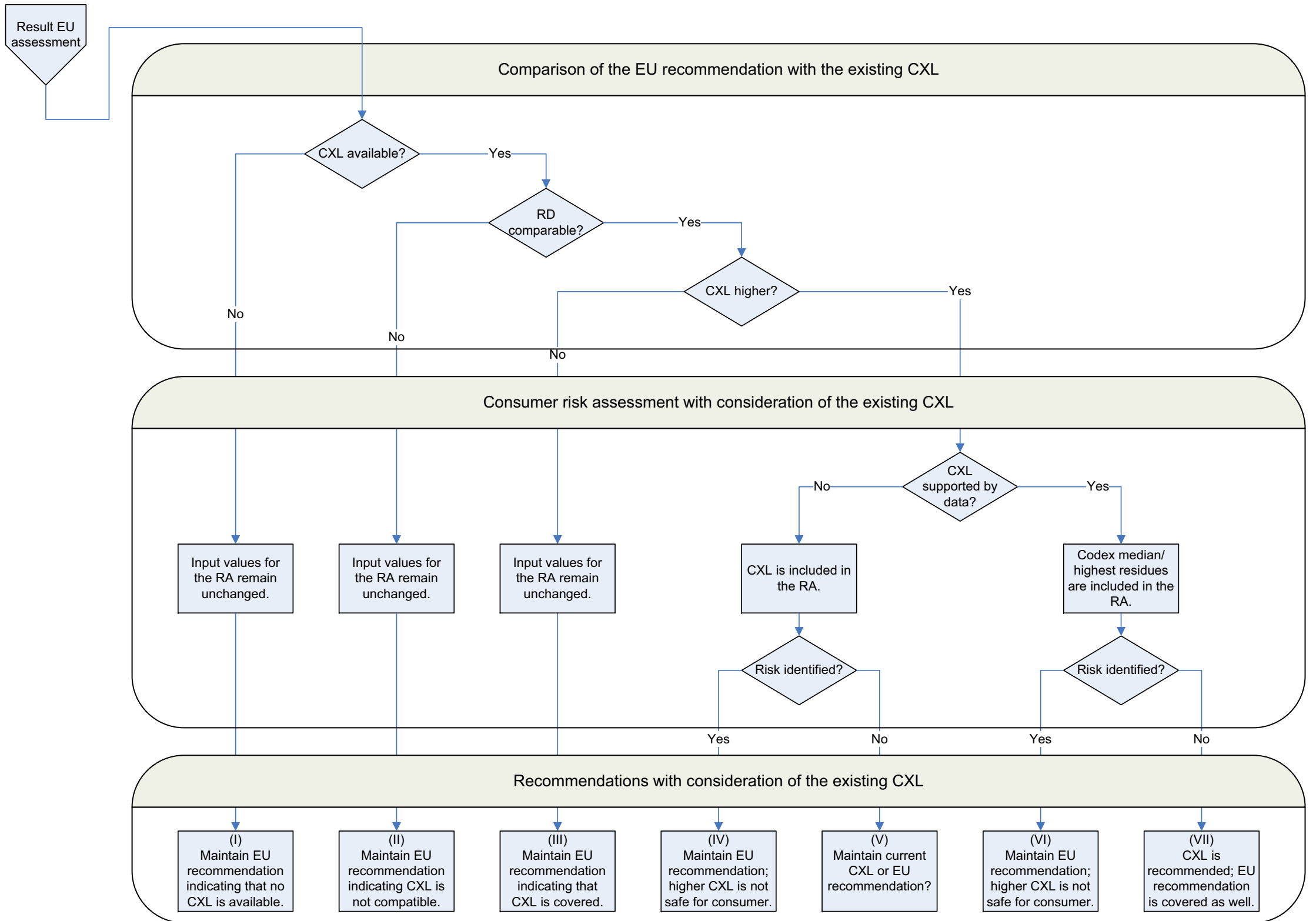




\section{Appendix F - Used compound codes}

\begin{tabular}{|c|c|c|}
\hline $\begin{array}{l}\text { Code/trivial } \\
\text { name }\end{array}$ & IUPAC name/SMILES notation/InChiKey ${ }^{(a)}$ & Structural formula(b) \\
\hline mandipropamid & $\begin{array}{l}(R S)-2-(4-c h l o r o p h e n y l)-N-[3-m e t h o x y-4-(\text { prop-2- } \\
\text { ynyloxy)phenethyl]-2-(prop-2-ynyloxy)acetamide } \\
\text { Clc1ccc(cc1)C(OCC\#C)C(=O)NCCc2ccc(OCC\#C)c } \\
(\mathrm{OC}) \mathrm{c} 2 \\
\text { KWLVWJPJKJMCSH-UHFFFAOYSA-N }\end{array}$ & \\
\hline SYN 500003 & $\begin{array}{l}N-\{(2 R S)-2-(4-c h l o r o p h e n y l)-2-[(\text { prop-2-yn-1-yl) } \\
\text { oxy]acetyl }\}-\beta \text {-alanine } \\
\text { Clc1ccc(cc1)C(OCC\#C)C }(=0) N C C C(=0) O \\
\text { ZNNAJYNLYSBVRG-UHFFFAOYSA-N }\end{array}$ & \\
\hline CGA 380778 & $\begin{array}{l}\text { (2RS)-2-(4-chlorophenyl)-2-hydroxy- } N-(2-\{3- \\
\text { methoxy-4-[(prop-2-yn-1-yl)oxy]phenyl\}ethyl) } \\
\text { acetamide } \\
\text { OC(c1ccc(Cl)cc1)C(=O)NCCc2ccc(OCC\#C)c(OC)c2 } \\
\text { CRJKRYZJRZIPJS-UHFFFAOYSA-N }\end{array}$ & \\
\hline NOA 458422 & $\begin{array}{l}\text { (2RS)-2-(4-chlorophenyl)-N-[2-(4-hydroxy-3- } \\
\text { methoxyphenyl)ethyl]-2-[(prop-2-yn-1-yl)oxy] } \\
\text { acetamide } \\
\text { Clc1ccc(cc1)C(OCC\#C)C(=O)NCCc2ccc(O)c(OC)c2 } \\
\text { HBYKLTZIVPBSNN-UHFFFAOYSA-N }\end{array}$ & \\
\hline
\end{tabular}

(a): ACD/Name 2015 ACD/Labs 2015 Release (File version N20E41, Build 75170, 19 December 2014).

(b): ACD/ChemSketch 2015 ACD/Labs 2015 Release (File version C10H41, Build 75059, 17 December 2014). 